\title{
Green Power Marketing in the United States: A Status Report (Ninth Edition)
}

Technical Report NREL/TP-640-40904

November 2006

Lori Bird and Blair Swezey

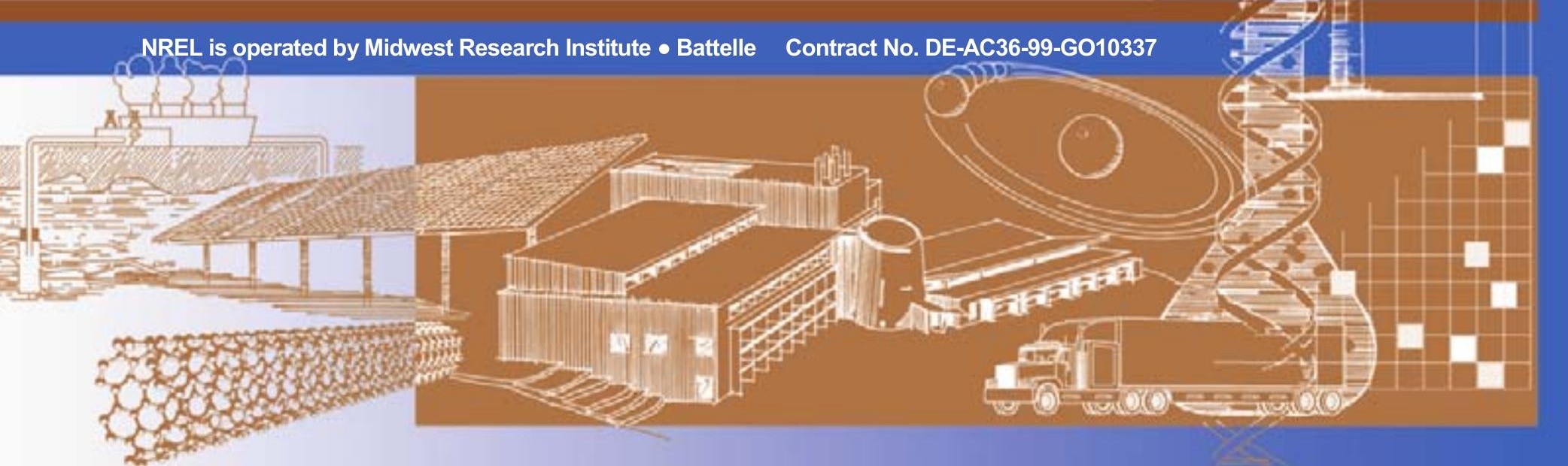




\section{Green Power Marketing in the United States: A Status Report (Ninth Edition)}

Lori Bird and Blair Swezey

Technical Report NREL/TP-640-40904

November 2006

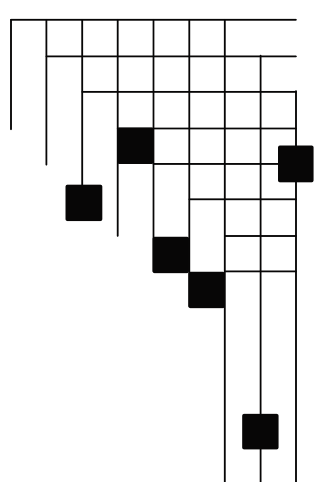




\section{NOTICE}

This report was prepared as an account of work sponsored by an agency of the United States government. Neither the United States government nor any agency thereof, nor any of their employees, makes any warranty, express or implied, or assumes any legal liability or responsibility for the accuracy, completeness, or usefulness of any information, apparatus, product, or process disclosed, or represents that its use would not infringe privately owned rights. Reference herein to any specific commercial product, process, or service by trade name, trademark, manufacturer, or otherwise does not necessarily constitute or imply its endorsement, recommendation, or favoring by the United States government or any agency thereof. The views and opinions of authors expressed herein do not necessarily state or reflect those of the United States government or any agency thereof.

Available electronically at http://www.osti.gov/bridge

Available for a processing fee to U.S. Department of Energy and its contractors, in paper, from:

U.S. Department of Energy

Office of Scientific and Technical Information

P.O. Box 62

Oak Ridge, TN 37831-0062

phone: 865.576 .8401

fax: 865.576 .5728

email: mailto:reports@adonis.osti.gov

Available for sale to the public, in paper, from:

U.S. Department of Commerce

National Technical Information Service

5285 Port Royal Road

Springfield, VA 22161

phone: 800.553.6847

fax: 703.605.6900

email: orders@ntis.fedworld.gov

online ordering: http://www.ntis.gov/ordering.htm 


\section{TABLE OF CONTENTS}

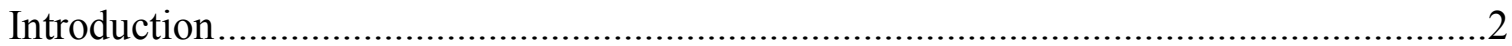

Green Power Market Summary and Trends...........................................................

Green Power Sales ......................................................................................4

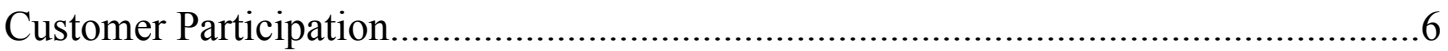

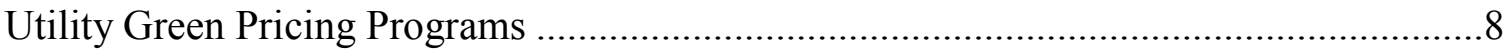

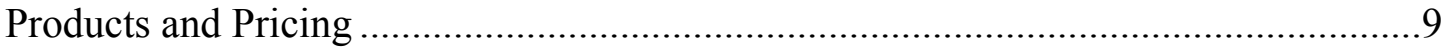

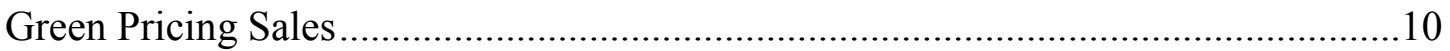

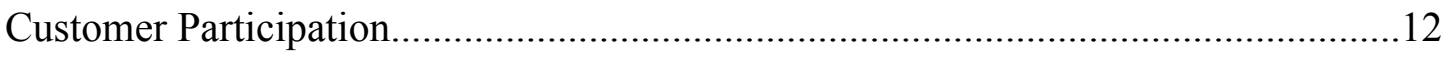

Competitive Green Power and REC Markets ........................................................14

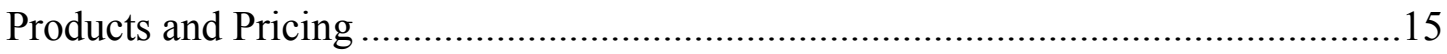

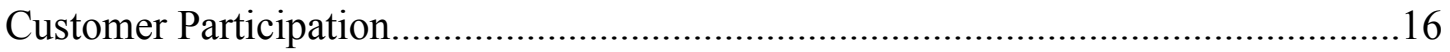

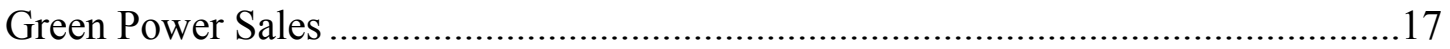

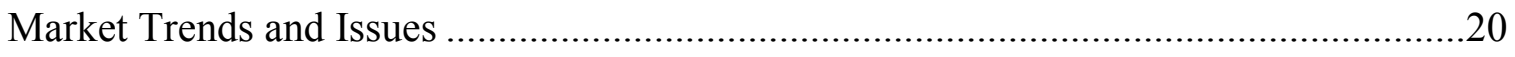

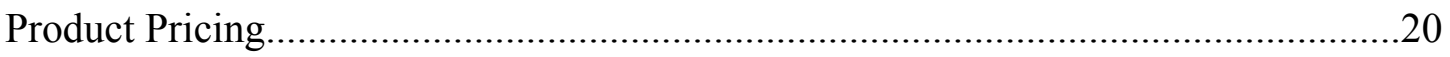

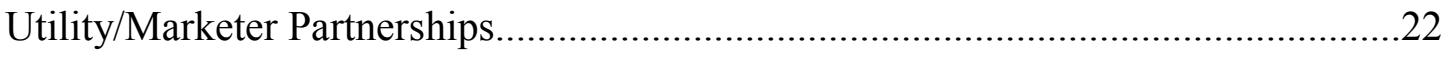

Interaction with Energy and Environmental Policies ............................................23

Is Green Power Simply an Evolutionary Step in Renewable Energy

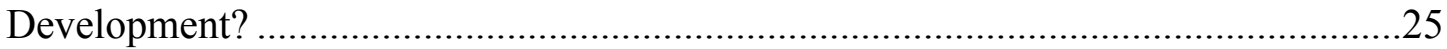

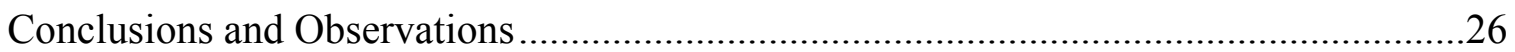

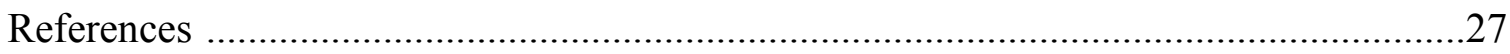

Appendix A - Estimates of New Renewable Energy Capacity Serving Green Power

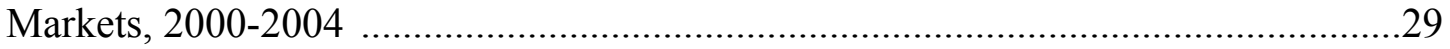

Appendix B - Top 25 Purchasers in the U.S. EPA Green Power Partnership,

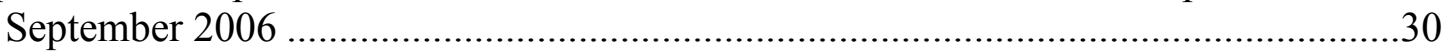

Appendix C - Estimated U.S. Green Power Customers by State, 2003 and 2004 ............31

Appendix D - Utilities Offering Green Pricing Programs in 2005 ...............................32

Appendix E - Utility Green Pricing Programs, November 2006 ..................................33

Appendix F - Utilities That Have Lowered Their Base Green Power Premium..............46

Appendix G - Retail Green Power Product Offerings in Competitive Electricity

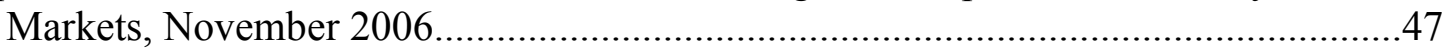

Appendix H - Renewable Energy Certificate Retail Products, November 2006 ..............51 


\section{LIST OF TABLES}

Table 1. Estimated Green Power Sales by Market Sector, 2003-2005 .............................5

Table 2. Estimated Green Power Sales by Customer Segment, 2004 and 2005 ................5

Table 3. Estimated Green Power Sales by Customer Segment and Market Sector, 2005

Table 4. Estimated Renewable Energy Capacity Supplying Green Power Markets, 2005

Table 5. Estimated Cumulative Green Power Customers by Market Segment, 2000-2005

Table 6. Price Differential Charged for Utility Green Power Products .............................9

Table 7. Annual Sales of Renewable Energy through Utility Green Pricing Programs ....11

Table 8. Renewable Energy Sources Supplying Utility Green Pricing Program, 2005 ....11

Table 9. Estimated Cumulative Number of Customer Participants in Utility Green

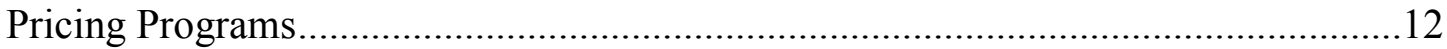

Table 10. Customer Participation Rates in Utility Green Pricing Programs by Year........13

Table 11. Estimated Cumulative Number of Customers Purchasing RECs or Green Power from Competitive Marketers, 2002-2004

Table 12. Retail Sales of Renewable Energy in Competitive Markets and RECs.

Table 13. Renewable Energy Sources Supplying Competitive and REC Markets, 2005

Table 14. Voluntary REC Offers and Pricing, October 2006.

Table A-1. Estimated Cumulative New Renewable Energy Capacity Supplying Green Power Markets, 2000-2004.

Table B-1. Top 25 Purchasers in the U.S. EPA Green Power Partnership, September 2006

Table C-1. Estimated U.S. Green Power Customers by State, 2003 and 2004 ................31

Table D-1. Utilities Offering Green Pricing Programs in 2005 ....................................32

Table E-1. Utility Green Pricing Programs, November 2006........................................33

Table F-1. Utilities That Have Lowered Their Base Green Power Premium ...................46

Table G-1. Retail Green Power Product Offerings in Competitive Electricity Markets, November 2006.

Table H-1. Renewable Energy Certificate Retail Products, November 2006 


\section{LIST OF FIGURES}

Figure 1. Number of Utilities and Electricity Suppliers Offering Green Power Options

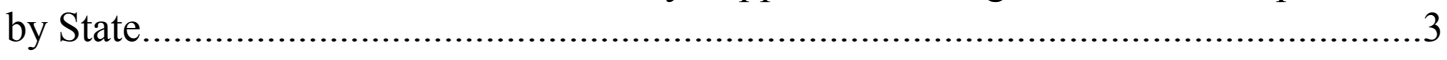

Figure 2. Estimated Green Power Sales by Renewable Energy Source, 2005 ....................4

Figure 3. U.S. Map of Utility Green Pricing Activities .................................................... 8

Figure 4. Trend in Utility Green Pricing Premiums, 2000-2005 …………………….....10

Figure 5. Utility Green Pricing Sales, 2000-2005 .........................................................11

Figure 6. States with Competitive Green Power Offerings ……………………............15

Figure 7. Trend in Green Power Purchase Contract Prices .............................................21 


\section{Acknowledgments}

This work was funded by the U.S. Department of Energy's (DOE) Office of Energy Efficiency and Renewable Energy (EERE). The authors wish to thank Linda Silverman and the EERE renewable energy technology programs for their support of this work. The authors also wish to thank Blaine Collison of the U.S. Environmental Protection Agency's Green Power Partnership, Susan Innis of Western Resource Advocates, Linda Silverman of DOE, and Doug Arent and Ron Benioff of the National Renewable Energy Laboratory (NREL) for their thoughtful review of the document, as well as Michelle Kubik of NREL for her editorial support. Finally, the authors thank the many green power marketers and utility contacts that provided the information summarized in this report. Additional information on green power market trends and activities can be found on the U.S. DOE's Green Power Network Web site (http://www.eere.energy.gov/greenpower/). 


\section{Introduction}

Voluntary consumer decisions to purchase electricity supplied from renewable energy sources represent a powerful market support mechanism for renewable energy development. Beginning in the early 1990s, a small number of U.S. utilities began offering "green power" options to their customers. ${ }^{1}$ Since then, these products have become more prevalent, both from traditional utilities and from marketers operating in states that have introduced competition into their retail electricity markets. Today, more than half of all U.S. electricity customers have an option to purchase some type of green power product from a retail electricity provider.

Currently, more than 600 utilities, or about $20 \%$ of utilities nationally, offer green power programs to customers. These programs allow customers to purchase some portion of their power supply as renewable energy — almost always at a higher price — or to contribute funds for the utility to invest in renewable energy development. The term "green pricing" is typically used to refer to these utility programs offered in regulated or noncompetitive electricity markets.

In states with competitive (or restructured) retail electricity markets, electricity customers can often purchase electricity generated from renewable sources by switching to an alternative electricity supplier that offers green power. In some of these states, default utility electricity suppliers offer green power options to their customers in conjunction with competitive green power marketers. ${ }^{2}$ To date, nearly a dozen states that have opened their markets to retail competition have experienced some green power marketing activity. Through the combination of utility green pricing and competitive retail markets, green power is available to most electricity customers living in 44 out of the 50 U.S. states (Figure 1).

Finally, regardless of whether they have access to a green power product from their retail power provider, any consumer can purchase green power through renewable energy certificates (RECs), which represent the "attributes" of electricity generated from renewable energy-based projects. Consumers in competitive markets can also support renewable energy development through REC purchases without having to switch to an alternative electricity supplier. Today, several dozen companies actively market RECs to residential or business customers throughout the United States.

This report documents green power marketing activities and trends in the United States. First, we present aggregate green power sales data for all voluntary purchase markets across the United States. The next two sections provide summary data on (1) utility green pricing programs offered in regulated electricity markets and (2) green power marketing activity in competitive electricity markets and green power sold to voluntary purchasers in the form of RECs. These are followed by a discussion of key market trends and issues. The final section offers conclusions and observations. The data presented in this report are based on figures provided to NREL by utilities and independent renewable energy marketers. ${ }^{3}$

\footnotetext{
${ }^{1}$ The term "green power" generally refers to electricity supplied in whole or in part from renewable energy sources, such as wind and solar power, geothermal, hydropower, and various forms of biomass.

${ }^{2}$ Under these programs, consumers can purchase renewable energy from independent renewable energy marketing companies without switching their electricity service from the default or standard offer service provider.

${ }^{3}$ Green power market data for previous years are available in Bird and Swezey (2005a), Bird and Swezey (2004), Bird and Swezey (2003), Swezey and Bird (2000), Swezey and Bird (1999).
} 


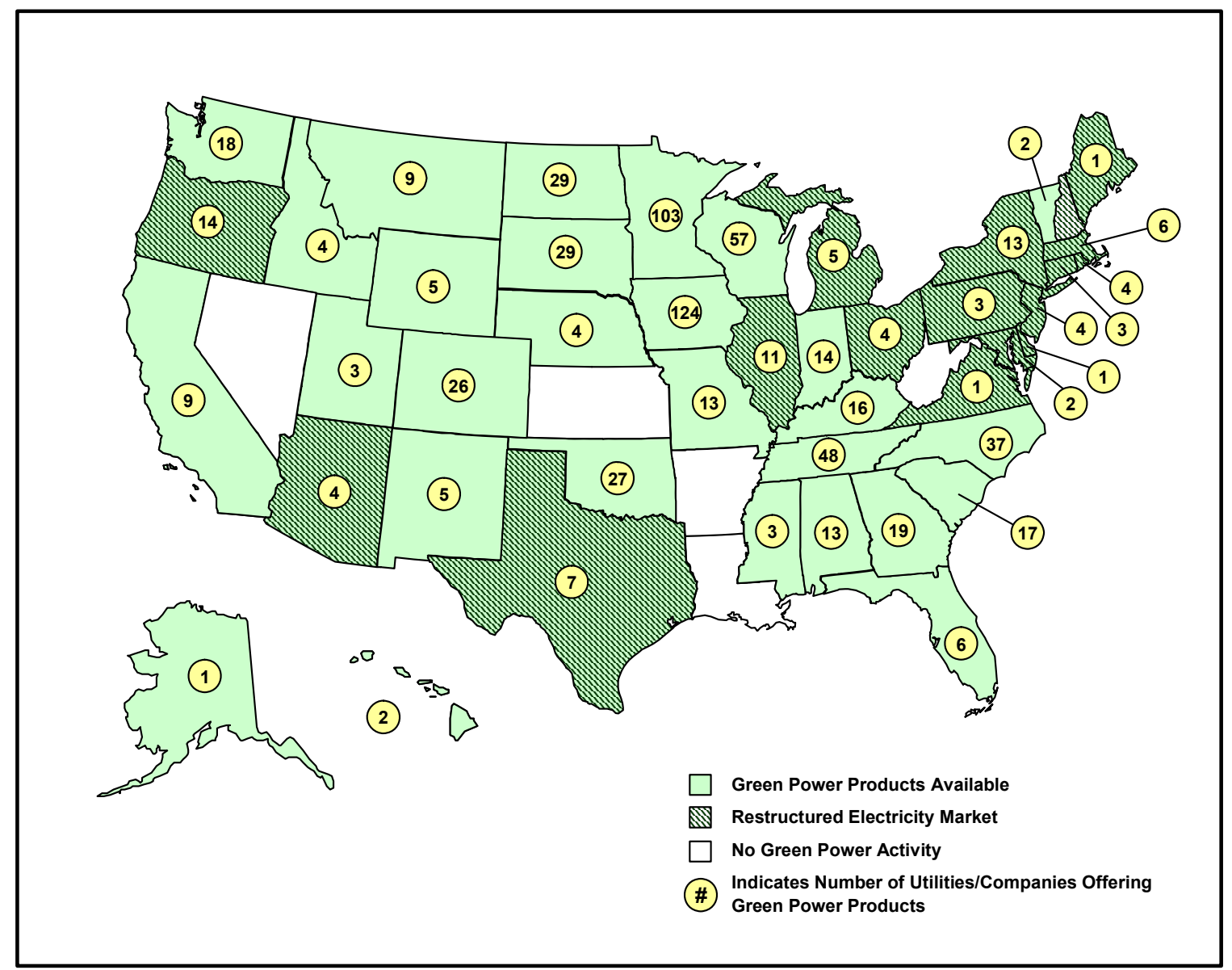

Figure 1: Number of Utilities and Electricity Suppliers Offering Green Power Options by State 


\section{Green Power Market Summary and Trends}

\section{Green Power Sales}

Overall, retail sales of renewable energy in voluntary purchase markets totaled 8.5 billion kilowatt-hours (kWh) in 2005 , or about $0.2 \%$ of total U.S. electricity sales. ${ }^{4}$ This include sales of renewable energy derived from both "new" and "existing" renewable energy sources, with most sales supplied from new sources. ${ }^{5}$ Wind energy provided $61 \%$ of green power sales, followed by biomass energy sources, including landfill gas (27\%), hydropower $(6 \%)$, geothermal (5\%), and solar (1\%) (Figure 2). Based on the sales and pricing data presented in this report, we estimate the market value of green power sales in 2005 to be from $\$ 50$ million to $\$ 70$ million.

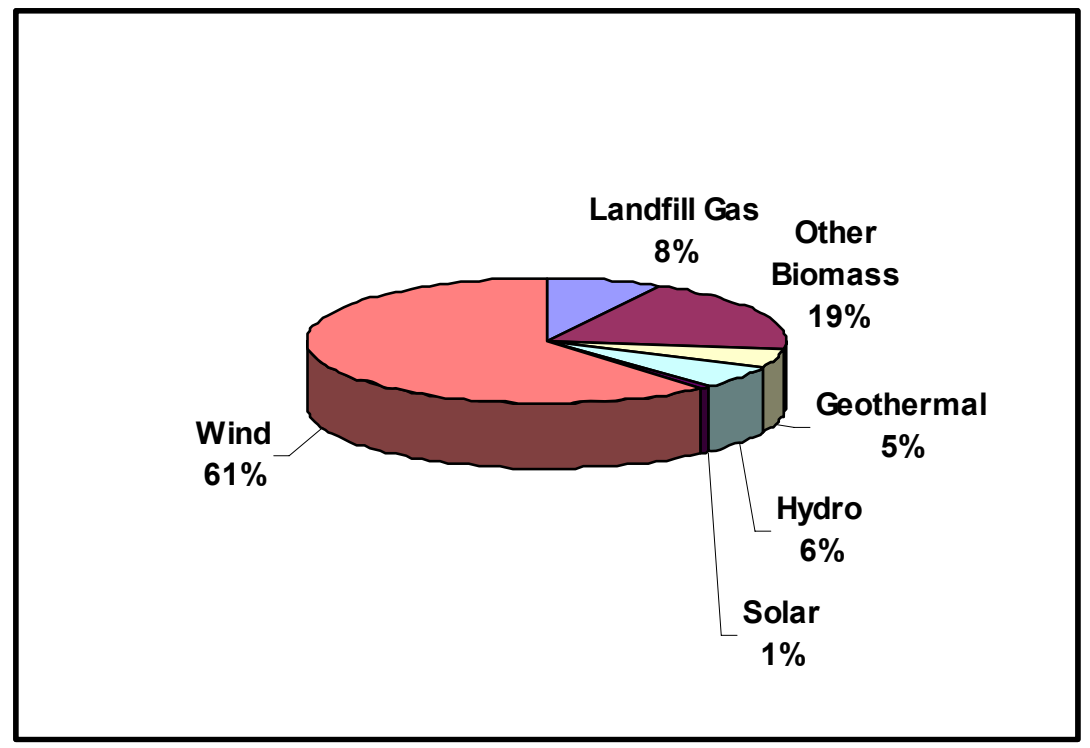

Figure 2: Estimated Green Power Sales by Renewable Energy Source, 2005

Green power sales increased by $37 \%$ on an energy basis in 2005, following growth of about $60 \%$ in 2004 (Table 1). REC sales more than doubled in 2005, while sales through utility green pricing programs also exhibited strong annual growth of more than $30 \% .{ }^{6}$ However, sales in competitive markets fell by about $20 \%$, because rising costs associated with supplying customers with renewable electricity service caused some marketers to lose or turn back customers to

\footnotetext{
${ }^{4}$ U.S. electricity sales totaled 3,660 billion $\mathrm{kWh}$ in 2005, according to the U.S. Energy Information Administration (EIA). See http://www.eia.doe.gov/cneaf/electricity/epa/epat7p2.html.

${ }^{5}$ With green power, a distinction is often made based on the vintage of the renewable energy generator. The green power industry generally follows the Green-e national standard, which defines a "new" renewable generation facility as one placed in operation or repowered on or after January 1, 1997. An "existing" generation facility, therefore, is one placed in service before January 1, 1997. For more information on the Green-e national standard, see http://www.green-e.org/ipp/national_standard.html.

${ }^{6}$ The REC sales figures reflect sales to end use customers separate from electricity. RECs bundled with electricity and sold to end use customers through utility green pricing programs or in competitive electricity markets are counted in these other categories.
} 
default service (see the competitive markets discussion). REC markets now represent nearly half of industry sales, replacing competitive markets as the dominant market sector.

The year 2005 marked the first year that the majority of green power sales were made to nonresidential customers, representing $65 \%$ of sales, up from about $45 \%$ in 2004 (Table 2). In fact, during 2005, nonresidential sales doubled, while sales to residential customers declined by $14 \%$. Although sales to residential customers through utility green pricing programs increased in 2005, losses in some competitive markets, such as Pennsylvania and Virginia, led to the overall decline in residential sales. Nearly all REC sales were to nonresidential customers, while residential customers played a larger role in green pricing programs and competitive markets, where they accounted for more than $60 \%$ of renewable energy sales (Table 3).

At the end of 2005, sales of renewable energy in voluntary markets represented a generating capacity equivalent of about 2,500 MW, with more than 2,000 MW from new renewable energy sources (Table 4). Since 2000, the amount of renewable energy capacity serving green power markets has increased more than 10-fold (see Appendix A).

Table 1: Estimated Green Power Sales by Market Sector, 2003-2005* (millions of kWh)

\begin{tabular}{|l|c|c|c|c|c|}
\hline Market Sector & $\mathbf{2 0 0 3}$ & $\mathbf{2 0 0 4}$ & $\mathbf{2 0 0 5}$ & $\begin{array}{c}\mathbf{\%} \text { Change } \\
\mathbf{2 0 0 4 / 2 0 0 3}\end{array}$ & $\begin{array}{c}\mathbf{\%} \text { Change } \\
\mathbf{2 0 0 5 / 2 0 0 4}\end{array}$ \\
\hline Utility Green Pricing & 1,280 & 1,840 & 2,450 & $44 \%$ & $33 \%$ \\
\hline Competitive Markets & 1,900 & 2,650 & 2,150 & $39 \%$ & $-19 \%$ \\
\hline REC Markets & 660 & 1,720 & 3,890 & $161 \%$ & $126 \%$ \\
\hline Retail Total & $\mathbf{3 , 8 4 0}$ & $\mathbf{6 , 2 1 0}$ & $\mathbf{8 , 4 9 0}$ & $\mathbf{6 2 \%}$ & $\mathbf{3 7 \%}$ \\
\hline
\end{tabular}

*Includes sales of new and existing renewable energy.

Table 2: Estimated Green Power Sales by Customer Segment, 2004 and 2005 (millions of kWh)

\begin{tabular}{|l|c|c|c|}
\hline Customer Segment & $\mathbf{2 0 0 4}$ & $\mathbf{2 0 0 5}$ & \% Change \\
\hline Residential & 3,480 & 2,980 & $-14 \%$ \\
\hline Nonresidential & 2,740 & 5,510 & $101 \%$ \\
\hline Total $^{*}$ & $\mathbf{6 , 2 1 0}$ & $\mathbf{8 , 4 9 0}$ & $\mathbf{3 7 \%}$ \\
\hline$\%$ Nonresidential & $44 \%$ & $65 \%$ & -- \\
\hline
\end{tabular}

*Totals may not add due to rounding. 
Table 3: Estimated Green Power Sales by Customer Segment and Market Sector, 2005 (millions of kWh)

\begin{tabular}{|l|c|c|c|c|}
\hline Customer Segment & $\begin{array}{c}\text { Green } \\
\text { Pricing }\end{array}$ & $\begin{array}{c}\text { Competitive } \\
\text { Markets }\end{array}$ & $\begin{array}{c}\text { REC } \\
\text { Markets }\end{array}$ & Total \\
\hline Residential & 1,610 & 1,330 & 40 & 2,980 \\
\hline Nonresidential & 840 & 820 & 3,840 & 5,510 \\
\hline Total & $\mathbf{2 , 4 5 0}$ & $\mathbf{2 , 1 5 0}$ & $\mathbf{3 , 8 9 0}$ & $\mathbf{8 , 4 9 0}$ \\
\hline$\%$ Residential & $66 \%$ & $62 \%$ & $1 \%$ & $35 \%$ \\
\hline
\end{tabular}

Note: Totals may not add due to rounding.

Table 4: Estimated Renewable Energy Capacity Supplying Green Power Markets, 2005 (megawatts)

\begin{tabular}{|l|c|c|}
\hline Market & $\begin{array}{c}\text { Total Renewables } \\
\text { Capacity }\end{array}$ & $\begin{array}{c}\text { New } \\
\text { Renewables } \\
\text { Capacity }\end{array}$ \\
\hline Utility Green Pricing & 800 & 740 \\
\hline Competitive Markets/RECs & 1,710 & 1,300 \\
\hline Total & $\mathbf{2 , 5 1 0}$ & $\mathbf{2 , 0 4 0}$ \\
\hline
\end{tabular}

According to EIA, about 9,000 MW of new renewable energy capacity was installed in the United States between 1997 and the end of 2005; thus, voluntary green power markets provide support for $22 \%$ of new renewable energy capacity additions, nationally. ${ }^{7}$ Much of the remaining renewable energy generation from recent capacity additions is used for compliance with state renewable portfolio standards or other policy mandates, separate from voluntary green power markets.

\section{Customer Participation}

In 2005, nearly 600,000 electricity customers nationally purchased green power products through regulated utility companies, from green power marketers in a competitive market setting, or in the form of RECs (Table 5). ${ }^{8}$ In aggregate, utility green pricing programs have shown steady growth in customers over time as the number of utility programs has increased and as existing

\footnotetext{
${ }^{7}$ Excluding capacity losses over the period, 8,980 MW of new renewable energy capacity came online from 1997 through 2005. Data from EIA Renewable Energy Annual reports, various years, http://www.eia.doe.gov/cneaf/solar.renewables/page/rea_data/rea_sum.html with 2005 data derived from projections contained in the EIA Annual Energy Outlook 2006 http://www.eia.doe.gov/oiaf/aeo/aeoref tab.html.

${ }^{8}$ It is important to note that there is greater uncertainty in our customer estimates for competitive and REC markets because of data limitations. For more detailed estimates by state for 2003 and 2004, see data from U.S. EIA 2006a in Appendix C. Generally, our estimates are consistent with the EIA estimates when adjusted for customers in Ohio who participate in community aggregations. We exclude these customers from our estimates because they purchase products with very low renewable energy content ( $1 \%$ to $2 \%)$.
} 
programs have grown. On the other hand, competitive markets have been less consistent. While green power sales have grown in Texas and some Northeast states, other markets have failed altogether - notably in California, Connecticut, and most recently Pennsylvania. While REC customers represent a small fraction of the total customer base, REC sales represent nearly half of all green power sales and have grown dramatically in recent years as a result of a number of very large purchases (see Appendix B for a list of top green power purchasers).

Average participation rates among utility green pricing programs increased slightly to $1.5 \%$ in 2005 , with a median value of $1.0 \%$; top performing programs have achieved rates ranging from $4 \%$ to $15 \%$. Competitive markets have experienced green power customer penetration rates ranging from $1 \%$ to $2 \%$ in states where the market has been conducive to retail competition.

Table 5: Estimated Cumulative Green Power Customers by Market Segment, 2000-2005

\begin{tabular}{|l|c|c|c|c|c|c|}
\hline & $\mathbf{2 0 0 0}$ & $\mathbf{2 0 0 1}$ & $\mathbf{2 0 0 2}$ & $\mathbf{2 0 0 3}$ & $\mathbf{2 0 0 4}$ & $\mathbf{2 0 0 5}$ \\
\hline Utility Green Pricing & $130,000^{\mathrm{a}}$ & $170,000^{\mathrm{a}}$ & $230,000^{\mathrm{a}}$ & 270,000 & 330,000 & 390,000 \\
\hline Competitive Markets & $>160,000^{\mathrm{b}}$ & $>110,000^{\mathrm{b}}$ & $\sim 150,000$ & $>170,000^{\mathrm{c}}$ & $>140,000^{\mathrm{c}}$ & $>180,000$ \\
\hline REC Markets & -- & - & $<10,000$ & $<10,000$ & $<10,000$ & $<10,000$ \\
\hline Retail Total & $\mathbf{2 9 0 , 0 0 0}$ & $>\mathbf{2 8 0 , 0 0 0}$ & $\sim \mathbf{3 9 0 , 0 0 0}$ & $\mathbf{\sim 4 5 0 , 0 0 0}$ & $\mathbf{\sim 4 8 0 , 0 0 0}$ & $\sim \mathbf{5 8 0 , 0 0 0}$ \\
\hline \% Change & $\mathbf{n} / \mathbf{a}$ & $\mathbf{- 3} \%$ & $\mathbf{3 9 \%}$ & $\mathbf{1 5 \%}$ & $\mathbf{7 \%}$ & $\mathbf{2 1 \%}$ \\
\hline
\end{tabular}

${ }^{a}$ Estimates have been adjusted downward from those originally reported in Bird and Swezey (2003) because of program participation revisions made by the Los Angeles Department of Water and Power.

${ }^{b}$ Includes only customers purchasing Green-e certified green power products, as reported by the Center for Resource Solutions (2001; 2002).

${ }^{c}$ Estimates have been adjusted from those originally reported in Bird and Swezey (2005a) based on data available in U.S. EIA 2006a (see Appendix C). 


\section{Utility Green Pricing Programs}

The number of utilities offering green pricing has grown steadily in recent years - today, more than 600 investor-owned, public, and cooperative utilities in 36 states offer green pricing programs (Figure 3). Appendix D provides a list of utilities offering green pricing while Appendix E provides detailed program information. ${ }^{9}$ Because a number of small municipal or cooperative utilities offer programs developed by their power suppliers, the number of distinct green pricing programs is about 130. Since 1999, between 10 and 25 new programs have been added each year. Initially, some portion of the growth in utility green power offerings was attributable to the threat of retail market competition, while more recent growth has been spurred by state laws requiring utilities to offer green pricing. ${ }^{10}$ In addition, a number of utilities have expanded their programs as customer demand has grown.

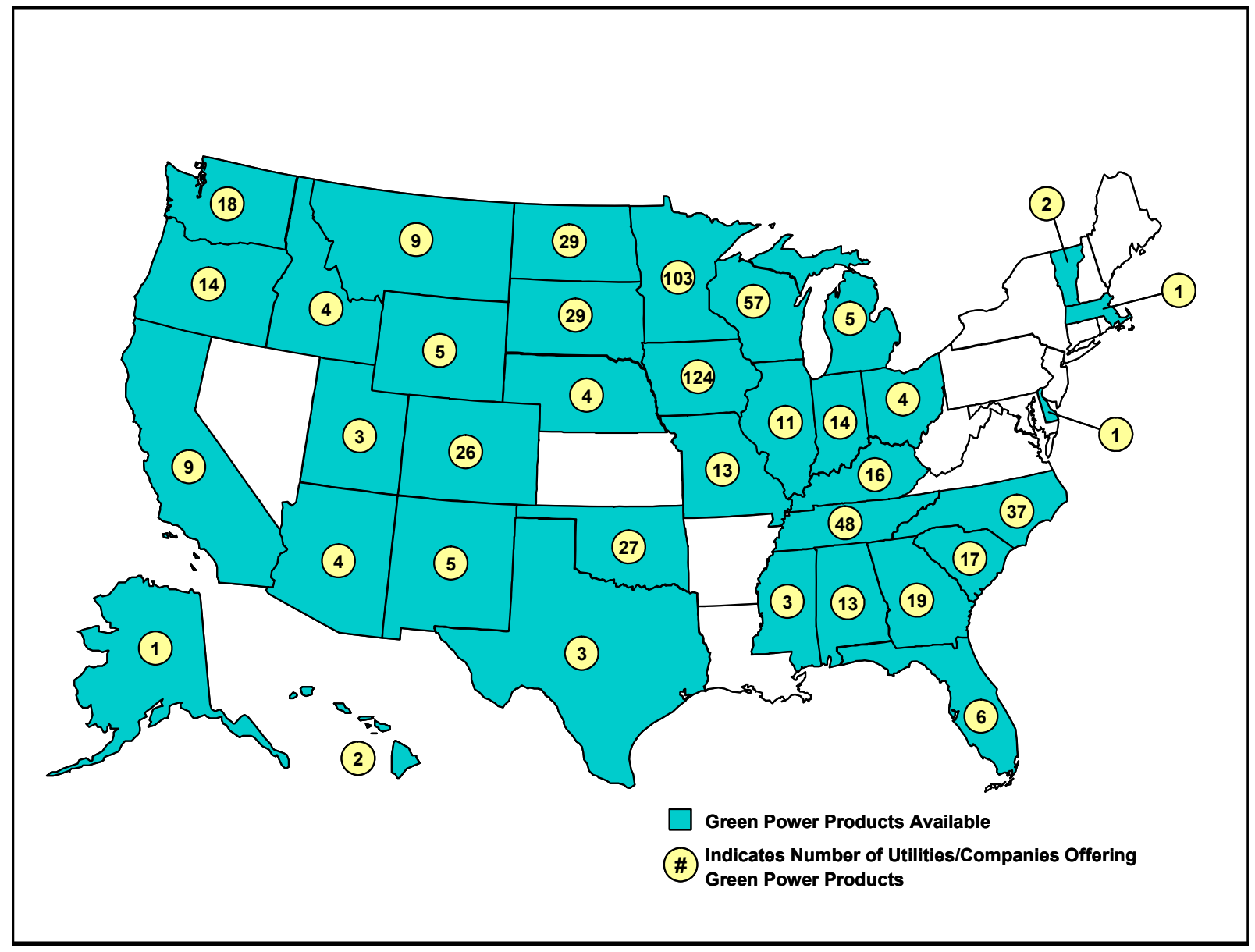

Figure 3: U.S. Map of Utility Green Pricing Activities

\footnotetext{
${ }^{9}$ For an up-to-date list of utilities with green pricing programs, see the U.S. Department of Energy's Green Power Network Web site at http://www.eere.energy.gov/greenpower/markets/pricing.shtml?page=1.

${ }^{10}$ These states include Iowa, Minnesota, Montana, New Mexico, Oregon, and Washington.
} 


\section{Products and Pricing}

Typically, green pricing programs are structured so that customers can either purchase green power for a certain percentage of their electricity use (often called "percent-of-use products") or in discrete amounts or blocks at a fixed price ("block products"), such as a 100-kWh block. Most utilities offer block products but may also allow customers to purchase green power for their entire monthly electricity use. Utilities that offer percent-of-use products generally allow residential customers to elect to purchase $25 \%, 50 \%$, or $100 \%$ of their electricity use as renewable energy, while a few offer fractions as small as 10\%. Under these types of programs, larger purchasers, such as businesses, can often purchase green power for a smaller fraction of their electricity use.

In 2005 , the price differentials charged in green pricing programs ranged from $-0.67 \phi / \mathrm{kWh}$ to as much as $17.6 \phi / \mathrm{kWh}$, with a mean of $2.36 \phi / \mathrm{kWh}$ and a median of $2.0 \phi / \mathrm{kWh}$ (Table 6). Programs that feature solar-based products represent the high end of the range.

Table 6: Price Differential Charged for Utility Green Power Products $(\boldsymbol{c} / \mathbf{k W h})$

\begin{tabular}{|l|c|c|c|c|c|c|c|}
\hline & $\mathbf{1 9 9 9}$ & $\mathbf{2 0 0 0}$ & $\mathbf{2 0 0 1}$ & $\mathbf{2 0 0 2}$ & $\mathbf{2 0 0 3}$ & $\mathbf{2 0 0 4}$ & $\mathbf{2 0 0 5}$ \\
\hline Average & 2.15 & 3.48 & 2.93 & 2.82 & 2.62 & 2.45 & 2.36 \\
\hline Median & 2.00 & 2.50 & 2.50 & 2.50 & 2.00 & 2.00 & 2.00 \\
\hline Range & $0.4-5.0$ & $(0.5)-20.0$ & $0.9-17.6$ & $0.7-17.6$ & $0.6-17.6$ & $0.33-17.6$ & $(0.67)-17.6$ \\
\hline $\begin{array}{l}\text { Lowest Premium } \\
\text { Programs* }\end{array}$ & $0.4-2.5^{\star *}$ & $(0.5)-2.5$ & $1.0-1.5$ & $0.7-1.5$ & $0.6-1.3$ & $0.33-1.0$ & $(0.67)-0.91$ \\
\hline $\begin{array}{l}\text { No. of Programs } \\
\text { Represented }\end{array}$ & 24 & 50 & 60 & 80 & 91 & 101 & 104 \\
\hline
\end{tabular}

${ }^{*}$ Represents the 10 utility programs with the lowest price premiums for new renewable energy sources. In 2001 , a discrepancy exists between the low end of the range for all programs and the Top 10 programs, because the program with the lowest premium $(0.9 \phi / \mathrm{kWh})$ was either selling some existing renewables or had not installed any new renewable capacity for its program.

**Data for April 2000.

Source: Bird and Brown (2006a)

The average price premium has dropped at an annual average rate of about $8 \%$ since 2000 (Figure 4). Some of this reduction can be attributed to lower market costs for renewable energy supplies. Also, increases in the price of natural gas have narrowed the price gap between renewables and gas-fired generation alternatives, which has led to lower initial premiums for many new programs but has also reduced the effective premiums in programs that exempt participating customers from fuel-related price increases. ${ }^{11}$ In addition, a number of utilities have lowered their premiums over time to reflect changing market conditions (see Appendix F).

\footnotetext{
${ }^{11}$ Some utilities periodically adjust the green power premium to reflect changes in the cost of fossil fuels used for electricity generation. Other utilities offer a fixed-rate green power product. In either case, when fuel prices increase, the effective green power premium falls. Utilities offering fixed-rate green power options or other types of fuel-price exemptions include Austin Energy, Alliant Energy, Clallum County PUD, Edmond Electric, Eugene Water and Electric Board, Green Mountain Power, Holy Cross Energy, Madison Gas \& Electric, OG\&E Electric Services, We Energies, and Xcel Energy.
} 


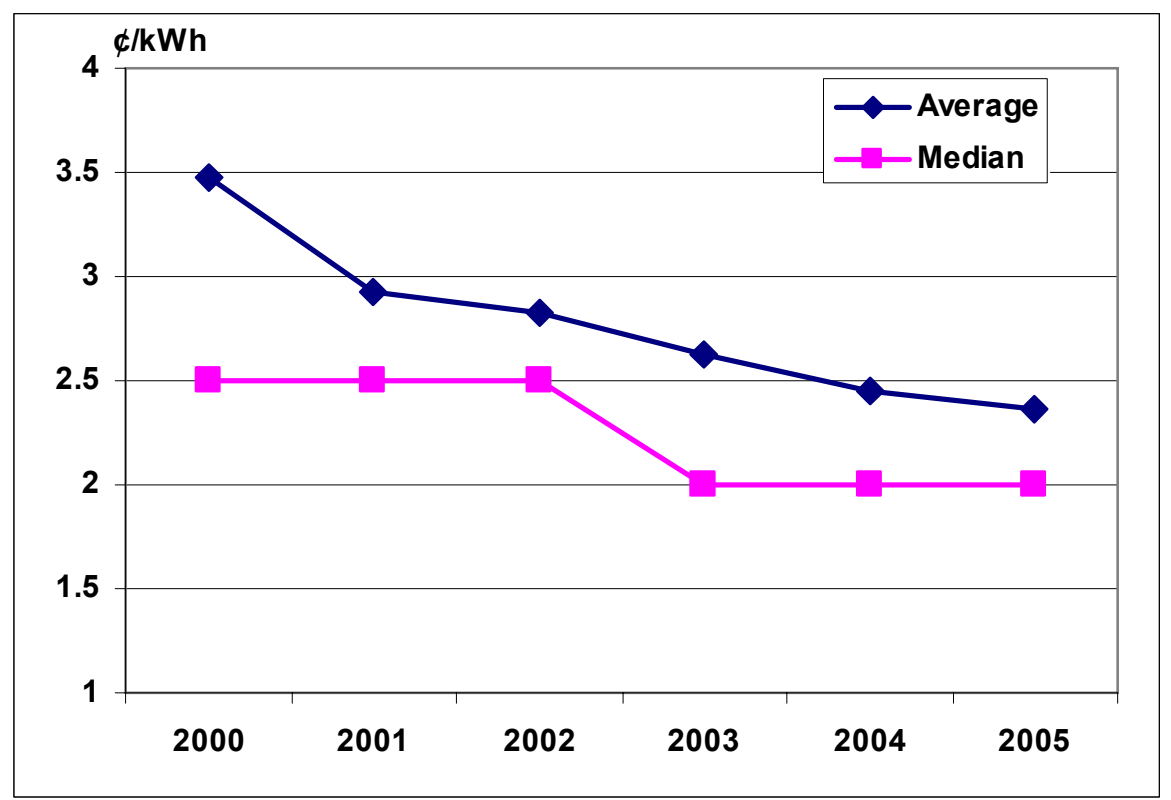

Figure 4: Trend in Utility Green Pricing Premiums, 2000-2005

A growing number of utilities also offer lower premiums for bulk green power purchases by larger nonresidential customers. ${ }^{12}$ In these programs, the premium charged to nonresidential customers can range from $0.5 \phi / \mathrm{kWh}$ to $2 \phi / \mathrm{kWh}$ less than the residential green energy premium. A number of these bulk purchase rates have been introduced in recent years to help utilities compete against low-priced REC offerings.

\section{Green Pricing Sales}

Utility green pricing sales continue to exhibit strong growth (Figure 5). Collectively, utilities in regulated electricity markets sold more than 2.4 billion $\mathrm{kWh}$ of green power to retail customers through green pricing programs in 2005 . Green power sales to all customer classes increased by $33 \%$ in 2005, compared to growth rates in excess of $40 \%$ in the past several years (Table 7).

Sales growth is attributed to both continued expansion of the green power customer base as well as larger purchases by nonresidential customers.

Renewable energy sold through green pricing programs in 2005 represents an equivalent renewable energy generation capacity of nearly $800 \mathrm{MW}$, with more than $740 \mathrm{MW}$ from new renewable energy resources (Table 8). Wind, solar, and landfill gas are the renewable resources most commonly used for utility programs, with wind energy representing the largest portion of the total capacity. Appendix A presents estimates of new capacity serving green pricing programs in previous years.

\footnotetext{
${ }^{12}$ These include Continental Cooperative Services/Soyland, Midstate Electric Cooperative, utilities participating in the NC Green Power Program, PacifiCorp, Portland General Electric, Puget Sound Energy, Salt River Project, We Energies, and Wisconsin Public Power Inc.
} 


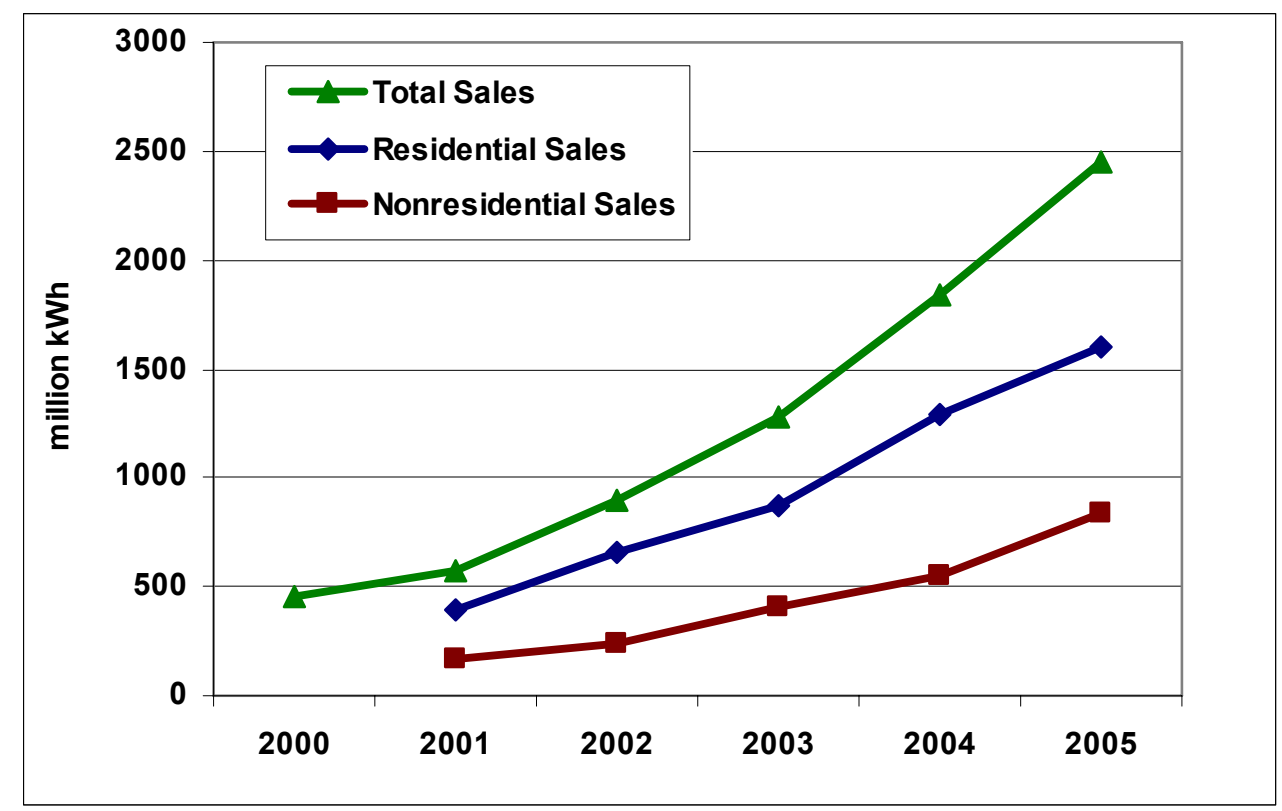

Figure 5: Utility Green Pricing Sales, 2000-2005

Table 7: Annual Sales of Renewable Energy through Utility Green Pricing Programs (millions of kWh)

\begin{tabular}{|l|r|r|r|r|r|r|}
\hline & $\mathbf{2 0 0 0}$ & $\mathbf{2 0 0 1}$ & $\mathbf{2 0 0 2}$ & $\mathbf{2 0 0 3}$ & $\mathbf{2 0 0 4}$ & $\mathbf{2 0 0 5}$ \\
\hline Sales to Residential Customers & --- & 400 & 661 & 874 & 1,295 & 1,606 \\
\hline Sales to Nonresidential Customers & --- & 173 & 234 & 410 & 544 & 842 \\
\hline Total Sales to All Customers & 454 & 573 & 895 & 1,284 & 1,839 & 2,448 \\
\hline \% Annual Growth in Total Sales & --- & $26 \%$ & $56 \%$ & $43 \%$ & $43 \%$ & $33 \%$ \\
\hline \% Nonresidential of Total Sales & --- & $30 \%$ & $26 \%$ & $32 \%$ & $30 \%$ & $34 \%$ \\
\hline
\end{tabular}

*Sales information by customer segment not available for 2000.

Source: Bird and Brown (2006a)

Table 8: Renewable Energy Sources Supplying Utility Green Pricing Programs, 2005

\begin{tabular}{|l|c|c|c|c|c|c|c|c|}
\hline & $\begin{array}{c}\text { Landfill } \\
\text { Gas }\end{array}$ & Digesters & Wood & $\begin{array}{c}\text { Geo- } \\
\text { thermal }\end{array}$ & Hydro & Solar & Wind & Total \\
\hline Sales (MWh) & 323,000 & 28,000 & 63,000 & 72,000 & 97,000 & 6,000 & $1,859,000$ & $2,448,000$ \\
\hline$\%$ of Total Sales & $13 \%$ & $1 \%$ & $3 \%$ & $3 \%$ & $4 \%$ & $<1 \%$ & $76 \%$ & $100 \%$ \\
\hline$\%$ New Sales & $59 \%$ & $100 \%$ & $88 \%$ & $4 \%$ & $12 \%$ & $100 \%$ & $99 \%$ & $87 \%$ \\
\hline Capacity Factor & $90 \%$ & $90 \%$ & $80 \%$ & $90 \%$ & $50 \%$ & $20 \%$ & $30 \%$ & n/a \\
\hline Total MW & 41 & 4 & 9 & 9 & 22 & 3 & 707 & 796 \\
\hline MW New RE & 24 & 4 & 8 & $<1$ & 3 & 3 & 702 & 744 \\
\hline
\end{tabular}

* Capacity factors are derived from EPRI/DOE 1997 and EIA 2006b to reflect a blend of technologies installed over time and in areas with varying resource quality. 


\section{Customer Participation}

At the end of 2005, nearly 400,000 customers were participating in utility green pricing programs nationwide, including more than 11,000 nonresidential customers. ${ }^{13}$ From 1999 to 2005, the number of customer participants increased nearly six-fold, with growth rates in recent years ranging from $16 \%$ to $35 \%$.

Table 9 delineates residential and nonresidential customer participation in utility green pricing programs over time. The vast majority of participants are residential customers; nonresidential customers accounted for only $3 \%$ of all participants in 2005 . However, nonresidential participation is growing at a faster rate than residential participation, which is having a significant positive impact on overall sales volume because of the larger size of nonresidential purchases.

Table 9: Estimated Cumulative Number of Customer Participants in Utility Green Pricing Programs

\begin{tabular}{|c|c|c|c|c|c|c|c|}
\hline Customer Segment & 1999 & 2000 & 2001 & 2002 & 2003 & 2004 & 2005 \\
\hline Residential & $\mathrm{n} / \mathrm{a}^{*}$ & 131,000 & 166,300 & 224,500 & 258,700 & 323,700 & 383,400 \\
\hline Nonresidential & $\mathrm{n} / \mathrm{a}^{*}$ & 1,700 & 2,500 & 3,900 & 6,500 & 8,100 & 11,300 \\
\hline Total & 66,900 & 132,700 & 168,800 & 228,400 & 265,000 & 331,800 & 394,700 \\
\hline$\%$ Total Annual Growth & $\mathrm{n} / \mathrm{a}$ & $98 \%$ & $27 \%$ & $35 \%$ & $16 \%$ & $25 \%$ & $19 \%$ \\
\hline$\%$ Residential Growth & $\mathrm{n} / \mathrm{a}$ & $\mathrm{n} / \mathrm{a}$ & $27 \%$ & $35 \%$ & $15 \%$ & $25 \%$ & $18 \%$ \\
\hline$\%$ Nonresidential Growth & $\mathrm{n} / \mathrm{a}$ & $\mathrm{n} / \mathrm{a}$ & $47 \%$ & $56 \%$ & $67 \%$ & $25 \%$ & $40 \%$ \\
\hline
\end{tabular}

*Information on residential and nonresidential participants is not available for 1999.

Source: Bird and Brown (2006a)

At the end of 2005, the average participation rate in utility green pricing programs among eligible utility customers was $1.5 \%$, with a median of $1 \%$ (Table 10). These industry-wide rates have shown very little change in recent years. The overall lack of improvement in participation rates results from a number of factors, including a lack of customer awareness of the green power program, ${ }^{14}$ customer unwillingness to pay a premium for green power, customer uncertainty regarding the actual benefits of the program, and varied levels of interest among utilities in marketing and promoting the program (Holt and Holt 2004, Swezey and Bird 2001). However, the top performing programs continue to show improvement, with participation rates ranging from about $5 \%$ to nearly $14 \%$ in 2005 , compared to a range of $3 \%$ to $6 \%$ in 2002 .

In 2005, utilities reported that an average of $6.5 \%$ and a median of $5.1 \%$ of customers dropped out of green pricing programs, reversing a trend of increasing attrition rates during the past several years (Bird and Brown, 2006a). This finding is somewhat surprising in a year in which customers throughout the country faced higher electricity and energy prices. Although the reason

\footnotetext{
${ }^{13}$ NREL received participant and sales data for about $70 \%$ of utility green pricing programs in 2005 , including all of the major programs. The remaining programs, which are smaller in size, do not have a large impact on overall participant numbers.

${ }^{14}$ A number of utilities have reported that only $20 \%$ to $30 \%$ of their customers are aware that a green power option is offered.
} 
for the increase in customer retention is not clear, this finding suggests that customers are "sticky" and maintain participation in green power programs despite other energy cost increases.

Table 10: Customer Participation Rates in Utility Green Pricing Programs by Year

\begin{tabular}{|l|c|c|c|c|c|c|c|}
\hline Participation Rate & $\mathbf{1 9 9 9}$ & $\mathbf{2 0 0 0}$ & $\mathbf{2 0 0 1}$ & $\mathbf{2 0 0 2}$ & $\mathbf{2 0 0 3}$ & $\mathbf{2 0 0 4}$ & $\mathbf{2 0 0 5}$ \\
\hline Average & $0.9 \%$ & $1.2 \%$ & $1.3 \%$ & $1.2 \%$ & $1.2 \%$ & $1.3 \%$ & $1.5 \%$ \\
\hline Median & $0.8 \%$ & $0.7 \%$ & $0.7 \%$ & $0.8 \%$ & $0.9 \%$ & $1.0 \%$ & $1.0 \%$ \\
\hline Top 10 programs & $\begin{array}{c}2.1 \%- \\
4.7 \% *\end{array}$ & $\begin{array}{c}2.6 \%- \\
7.3 \%\end{array}$ & $\begin{array}{c}3.0 \%- \\
7.0 \%\end{array}$ & $\begin{array}{c}3.0 \%- \\
5.8 \%\end{array}$ & $\begin{array}{c}3.9 \%- \\
11.1 \%\end{array}$ & $\begin{array}{c}3.8 \%- \\
14.5 \%\end{array}$ & $\begin{array}{c}4.6 \%- \\
13.6 \%\end{array}$ \\
\hline
\end{tabular}

*Data for April 2000

Source: Bird and Brown (2006a) 


\section{Competitive Green Power and REC Markets}

About one-third of U.S. states have restructured their electricity markets to introduce retail service competition. Currently, electricity consumers in the following states can purchase competitively marketed green power: Connecticut, Maine, Maryland, Massachusetts, New Jersey, New York, Pennsylvania, Rhode Island, Texas, and Virginia, as well as the District of Columbia (Figure 6 and Appendix G). ${ }^{15,16}$

Initially, buying green power in competitive retail markets entailed switching service from the incumbent utility to a green power supplier. However, with few exceptions, green power marketers have found it difficult to compete or to persuade customers to switch suppliers. As a remedy, a number of states now require default suppliers (which are often the incumbent distribution utilities) to offer green power options to their customers. These suppliers typically provide customers with a choice of several products offered by competing green power marketers. In addition, several utility suppliers have voluntarily teamed with a single green power marketer to offer a green power option to their customers. Utility/marketer partnership programs are now offered in Connecticut, Massachusetts, New Jersey, New York, Pennsylvania, and Rhode Island.

RECs provide another alternative to switching electricity suppliers. Also known as "green tags" or tradable renewable certificates (TRCs), RECs represent the "green" attributes of renewable energy generation and can be sold separately from commodity electricity. REC-based products may be supplied from a variety of renewable energy sources throughout the country and sold to customers nationally; or they may be supplied from renewable energy sources in a particular region or locality and marketed as such to local customers. More than 20 companies offer certificate-based green power products to retail customers via the Internet, and a number of other companies market RECs solely to commercial and industrial customers (Appendix $\mathbf{H}){ }^{17}$

RECs are also sold in the wholesale market and are frequently used by utilities and marketers who bundle the RECs with commodity electricity to sell green power to retail customers. In fact, RECs are used to supply most of the programs in which default suppliers have teamed with green power marketers. Thus, it can be difficult to distinguish REC products from other green power offerings. This is particularly true when REC products are supplied from renewable sources located in the same region in which they are marketed.

\footnotetext{
${ }^{15}$ For an up-to-date list of products offered by competitive green power marketers, see the U.S. Department of Energy's Green Power Network Web site at http://www.eere.energy.gov/greenpower/markets/marketing.shtml?page $=1$

${ }^{16}$ We do not include Oregon and Ohio in this list. In Oregon, only large commercial and industrial customers are able to switch to competitive green power providers; residential and small commercial customers have access to green power options offered by the incumbent utilities, which we categorize as green pricing. In Ohio, at least one green power marketer supplied customers of municipal aggregation groups with a "cleaner energy" product, but the renewable energy content was very low (this offer was terminated at the end of 2005). Green power is not offered more broadly in the Ohio market.

${ }^{17}$ For an up-to-date list of companies offering REC-based green power products, see the U.S. Department of Energy’s Green Power Network Web site at: http://www.eere.energy.gov/greenpower/markets/certificates.shtml?page=1
} 


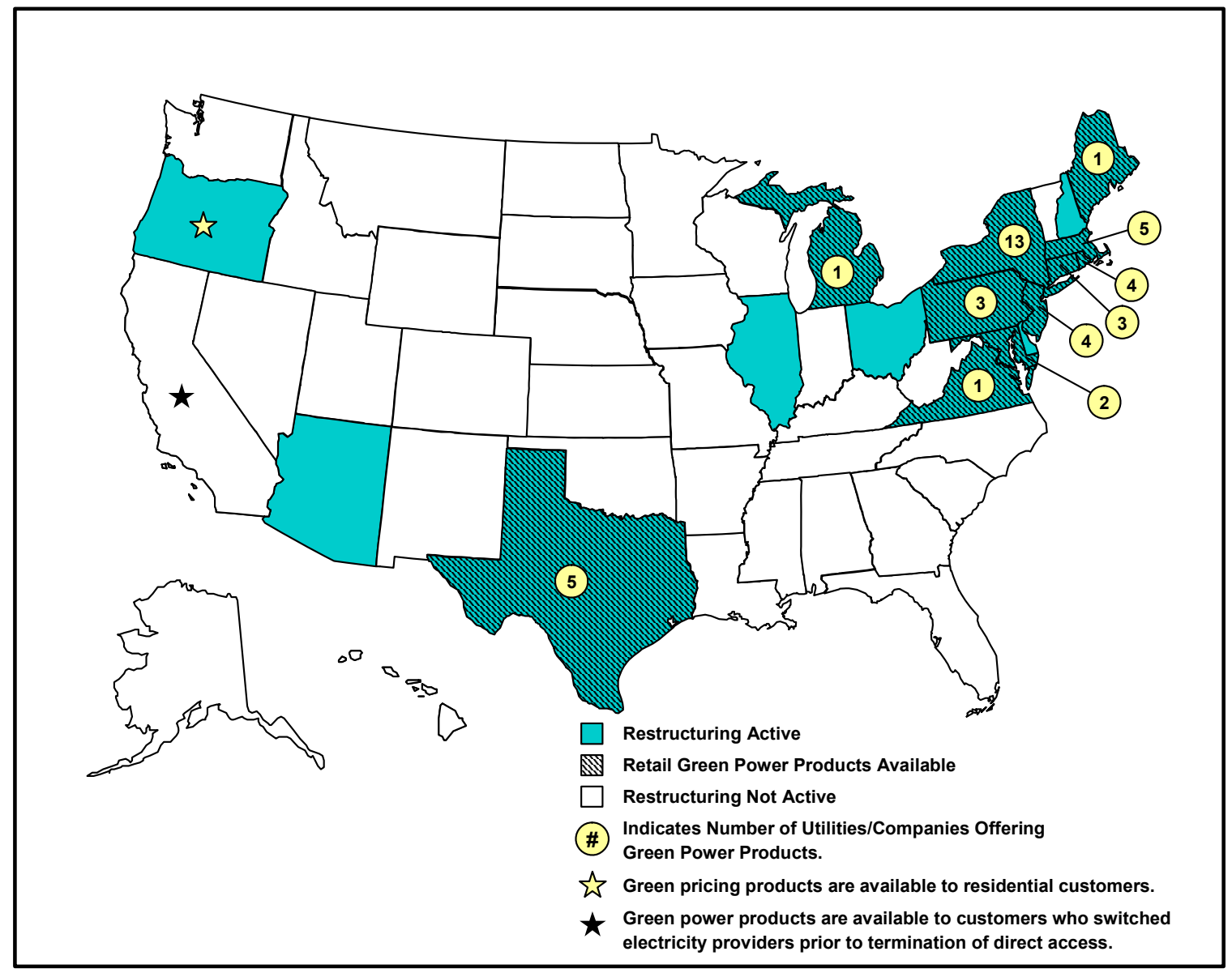

Figure 6: States with Competitive Green Power Offerings

\section{Products and Pricing}

Green power products offered in competitive markets tend to differ from those offered by utilities in regulated markets, in that they may contain a mix of electricity generated from new and preexisting renewable energy projects; whereas utility green pricing programs generally utilize only new renewable energy supplies. One reason for this is that competitive suppliers are subject to price competition, and existing resources are typically available at lower costs. Also, when markets initially opened to competition, green power marketers often were forced to offer existing renewables because of a lack of new renewable energy supplies. However, as new renewable energy facilities have come online, the fraction of new renewables in competitive retail products has increased. In addition, certification programs have required increasing amounts of new renewables. Effective January 1, 2007, the Green-e certification program will require all certified products to be supplied exclusively from new renewable energy projects. ${ }^{18}$ Similarly, the U.S. Environmental Protection Agency's (EPA) Green Power Partnership will

\footnotetext{
${ }^{18}$ Administered by the San Francisco-based Center for Resource Solutions, the Green-e program certifies retail and wholesale green power products that meet its environmental and product content standards. In 2005, the Green-e program certified about half of the renewable energy sold in the U.S. voluntary green power market. For details on the Green-e National Standard, see http://www.green-e.org/.
} 
require its partners to purchase new renewables to meet its minimum purchase criteria, starting in 2007. ${ }^{19}$

The price premium charged for competitive market products depends on several factors such as the price of standard offer or default service, the availability of incentives to green power marketers or suppliers, and the cost of renewable energy generation available in the regional market. Some marketers charge prices close to or even below the default market price; others offer fixed-price products at a premium, which provide customers with protection against increasing prices for a specified period of time, usually one year.

Competitively marketed green power products generally carry a price premium of between $1 \phi / \mathrm{kWh}$ and $2.5 \phi / \mathrm{kWh}$, although offerings range from discounts to a premium of about $10 \notin / \mathrm{kWh}$. During 2005, a number of marketers were forced to increase the price premiums for their products as a result of market conditions. The renewable energy sources most commonly used to supply competitive green power offerings are wind, landfill gas, and small or low-impact hydropower, while a number of products also contain a small amount of solar energy. Higherpriced products often contain a larger fraction of new renewable energy content or more desirable resources, such as new wind and solar.

Similar to competitively marketed products, retail prices charged for REC products typically range from about $1 \notin / \mathrm{kWh}$ to $2.5 \phi / \mathrm{kWh}$ for residential and small commercial customers. In most cases, larger customers are able to negotiate lower prices. Nearly all REC products are sourced from new renewable energy generation projects, which is a requirement of both Green-e certification and the EPA Green Power Partnership. Purchasers often seek certification out of concerns over "double counting" or because RECs are generally not subject to regulatory scrutiny.

Wind energy is the most commonly used renewable energy source for RECs, although some REC products feature other renewable energy sources or blends of renewable sources, such as biomass (typically from bio-methane sources) and solar.

\section{Customer Participation}

Based on data received from green power marketers, we estimate that as many as 200,000 retail customers were purchasing green power from competitive suppliers or as RECs at the end of 2005 (Table 11). This number includes about 60,000 participants in utility/marketer programs available in competitive markets. The number of customers participating in utility/marketer programs doubled during 2005 as these programs, most only recently launched, have begun to gain traction.

In competitive markets, the vast majority of customers purchasing green power are residential customers. Of the 200,000 retail customers, fewer than 10,000 purchase REC products. While most of the REC purchasers are also residential customers, the vast majority of REC sales are made to nonresidential customers due to the much larger purchase sizes.

\footnotetext{
${ }^{19}$ See http://www.epa.gov/greenpower.
} 
Table 11: Estimated Cumulative Number of Customers Purchasing RECs or Green Power from Competitive Marketers, 2002-2004

\begin{tabular}{|l|c|c|c|c|}
\hline & 2002 & 2003 & 2004 & 2005 \\
\hline Competitive Markets & $\sim 150,000$ & $\sim 170,000^{*}$ & $<140,000^{*}$ & $>180,000$ \\
\hline RECs & $<10,000$ & $<10,000$ & $<10,000$ & $<10,000$ \\
\hline Total & $<160,000$ & $\sim 180,000$ & $<150,000$ & $\sim 190,000$ \\
\hline$\%$ Change & n/a & $13 \%$ & $-17 \%$ & $27 \%$ \\
\hline
\end{tabular}

*Estimates are revised from those reported in Bird and Swezey (2005a) based on EIA data (EIA 2006a); see Appendix C. Customer numbers in competitive markets for 2003 were increased from the 150,000 originally reported to 170,000 , and 2004 customer numbers were adjusted downward from the 180,000 originally reported to 140,000 .

During 2005, most of the customer gains resulted from utility/marketer partnership programs in the Northeast. These gains were tempered by losses, particularly in Pennsylvania and Virginia, where marketers struggled to provide electricity service to consumers amidst adverse market conditions and increasing costs. For example, one marketer ceased offering electricity generation service to its 30,000 customers in late 2005, citing adverse market rules and conditions that increased its operating costs. The company instead began offering a REC-based product supplied from national renewable energy resources, but likely suffered losses when turning back its customers to default electricity service. ${ }^{20}$

\section{Green Power Sales}

An estimated 6 billion $\mathrm{kWh}$ of renewable energy was sold to retail customers by competitive and REC marketers in 2005 (Table 12). This figure includes renewable energy from both existing and new sources as well as that sold to customers in products that contain only a small percentage of renewable energy.

About 2.2 billion $\mathrm{kWh}$ of the total was sold as a bundled green power product in competitive electricity markets - nearly a 20\% decline from 2004. As noted earlier, the decline in sales in competitive markets occurred as a result of adverse market conditions and increasing costs of serving customers with electricity in states such as Pennsylvania and Virginia. The competitive market sales figure includes renewable energy sales through default utility/marketer programs or individual utility/marketer partnership in competitive markets, which amounted to approximately 290 million $\mathrm{kWh}$ in 2005. Retail REC sales more than doubled in 2005, reaching 3.9 billion $\mathrm{kWh}$. All of the growth in REC sales is attributable to the nonresidential sector.

\footnotetext{
${ }^{20}$ Green Mountain Energy Company News Release, October 11, 2005, “Green Mountain Energy Company Introduces New Renewable Energy Product in Pennsylvania." http://www.greenmountain.com/about/press events/prviewer.jsp?dbId=18, accessed November 10, 2006. Green Mountain quit the Ohio market at the same time, citing the Federal Energy Regulatory Commission's implementation of Seams Elimination Charge Adjustment and its resulting litigation, in addition to unexpected charges associated with the start of Midwest Independent Transmission System Operator Inc.'s Day II energy markets (see Austin Business Journal article, October 26, 2005 http://www.bizjournals.com/austin/stories/2005/10/24/daily30.html?from_rss=1).
} 
Table 12: Retail Sales of Renewable Energy in Competitive Markets and RECs (million kWh)

\begin{tabular}{|c|c|c|c|c|}
\hline & 2003 & 2004 & 2005 & $\begin{array}{l}\text { \% Change } \\
2005 / 2004\end{array}$ \\
\hline \multicolumn{5}{|c|}{ Competitive Markets } \\
\hline Residential & $\mathrm{n} / \mathrm{a}$ & 2,140 & 1,330 & $-38 \%$ \\
\hline Nonresidential & $\mathrm{n} / \mathrm{a}$ & 510 & 820 & $61 \%$ \\
\hline Subtotal & 1,900 & 2,650 & 2,150 & $-19 \%$ \\
\hline$\%$ Residential & & $81 \%$ & $62 \%$ & \\
\hline \multicolumn{5}{|l|}{ RECs } \\
\hline Residential & $\mathrm{n} / \mathrm{a}$ & 40 & 40 & $0 \%$ \\
\hline Nonresidential & $\mathrm{n} / \mathrm{a}$ & 1,690 & 3,840 & $127 \%$ \\
\hline Subtotal & 660 & 1,720 & 3,890 & $126 \%$ \\
\hline$\%$ Residential & & $2 \%$ & $1 \%$ & \\
\hline Total Sales & 2,560 & 4,370 & 6,040 & $38 \%$ \\
\hline
\end{tabular}

Table 12 also delineates green power sales by customer segment. In 2005, about $60 \%$ of green power sales in competitive markets were to residential customers, down from $80 \%$ in 2004 . In contrast, nearly all REC sales were to nonresidential customers. Generally, nonresidential customers find REC products attractive because of their flexibility and the greater potential for cost savings, ${ }^{21}$ whereas residential customers may be not be aware that RECs are available or may not understand them. For commercial and institutional customers that operate facilities in multiple locations across the country, RECs may also provide a more efficient green power sourcing solution than working with utilities in each individual utility territory. ${ }^{22}$

In 2005, renewable energy sold in competitive markets or as RECs represented an equivalent renewable energy capacity of more than $1,700 \mathrm{MW}$, with more than 1,300 MW of this total coming from new renewable energy resources (Table 13). Wind energy supplied 55\% of sales, followed by biomass (26\%), hydropower — often from small or low-impact installations- $(7 \%)$, landfill gas (6\%), geothermal (6\%), and solar (1\%).

\footnotetext{
${ }^{21}$ RECs can provide cost savings when they are sourced from renewable energy projects in more favorable resource locations and because the electricity need not be delivered directly to the customer, which lowers transaction costs.

${ }^{22}$ For example, the EPA Green Power Partnership reports that the majority of its top 25 partners purchase RECs (Appendix B). See http://www.epa.gov/greenpower/. In addition, the Green Power Market Development Group promotes the purchase of RECs among its members. See http://www.thegreenpowergroup.org/.
} 
Table 13: Renewable Energy Sources Supplying Competitive and REC Markets, 2005

\begin{tabular}{|l|c|c|c|c|c|c|c|}
\hline & Biomass & $\begin{array}{c}\text { Landfill } \\
\text { Gas }\end{array}$ & $\begin{array}{c}\text { Geo- } \\
\text { thermal }\end{array}$ & Hydro & Solar & Wind & Total \\
\hline MWh Sales & $1,542,000$ & 342,000 & 340,000 & 431,000 & 66,000 & $3,318,000$ & $6,040,000$ \\
\hline \% of Total Sales & $26 \%$ & $6 \%$ & $6 \%$ & $7 \%$ & $1 \%$ & $55 \%$ & $100 \%$ \\
\hline Estimated \% New & $10 \%$ & $75 \%$ & $1 \%$ & $10 \%$ & $100 \%$ & $95 \%$ & $\mathrm{n} / \mathrm{a}$ \\
\hline Capacity Factor* & $80 \%$ & $90 \%$ & $90 \%$ & $50 \%$ & $20 \%$ & $30 \%$ & $\mathrm{n} / \mathrm{a}$ \\
\hline Total MW & 220 & 43 & 43 & 98 & 38 & 1,263 & 1,706 \\
\hline MW New RE & $\mathbf{2 2}$ & $\mathbf{3 3}$ & $\mathbf{1}$ & $\mathbf{1 0}$ & $\mathbf{3 8}$ & $\mathbf{1 , 2 0 0}$ & $\mathbf{1 , 3 0 2}$ \\
\hline
\end{tabular}

* Capacity factors are derived from EPRI/DOE 1997 and EIA 2006b to reflect a blend of technologies installed over time and in areas with varying resource quality. 


\section{Market Trends and Issues}

Taken as a whole, the voluntary green power market continues to exhibit strong growth. However, green power markets do not operate in isolation from other markets and are also impacted by both state and federal policy initiatives and changes. In this section, we briefly describe a number of market and policy developments that will have an important influence on the future of green power markets.

\section{Product Pricing}

\section{Utility Green Pricing}

As noted previously, green power price premiums have been falling over time due to a combination of higher prices for conventional fuels and lower renewable energy costs. Nationally, the average premium charged in green pricing programs has fallen from $3.48 \notin / \mathrm{kWh}$ in 2000 to $2.36 \phi / \mathrm{kWh}$ in 2005 . Clearly, when the cost differential between renewable and conventional generation is narrowed, green power becomes a more attractive purchase option.

Several utilities exempt their green power customers from rate adjustments caused by changes in the prices of nonrenewable generation fuels. For three of these utilities, rising natural gas prices caused the green power price differential to turn negative at the end of 2005, that is, green power customers were actually paying less for their power than base rate customers. ${ }^{23}$ This situation led to a "run on the bank" which exhausted the green power supplies of two of the three utilities.

And three other utilities ${ }^{24}$ offer a fixed-rate green power product, which also provides customers with protection from fuel price changes. The most successful of these programs is the GreenChoice program offered by Austin Energy, which in 2005 accounted for nearly 20\% of all green power sales by the nation's utilities. The utility signs 10-year, fixed-price wind energy supply contracts and likewise requires its customers to commit to a 10 -year green power purchase. The program has proven extremely popular with larger commercial customers who, in addition to buying renewable energy, are able to lock in a hedge against future fossil energy price volatility. GreenChoice customers have also seen the utility's base rates rise above those charged for green power.

Why don't more utilities offer fixed-rate green power products or fuel-price exemptions? Utilities are generally risk averse and are concerned that customers will drop the green power service and leave the utility with "stranded" investment in renewable energy projects. Many utilities (and their regulators) strictly avoid any cross-subsidization between green power customers and other customer classes. The Austin Energy model works, in large measure, because the utility and city are willing to accept these risks. On the other hand, the great success of the Austin program clearly shows that customers place a high value on the fixed-price characteristic of the product. ${ }^{25}$

\footnotetext{
${ }^{23}$ The three utilities are Edmund Electric (Okla.), OG\&E Electric Services (Okla.), and Xcel Energy (Colorado program).

${ }_{24}$ The three utilities are Austin Energy (Tex.), Eugene Water and Electric Board (Ore.), and Clallum County Public Utility District (Wash.).

${ }^{25}$ A forthcoming NREL report will provide a detailed examination of fixed-rate green power products.
} 


\section{Renewable Energy Certificates}

Increasingly, REC sales have come to dominate the green power market. In particular, large national-scale companies and organizations find RECs to be an attractive green power option because of the greater flexibility they offer in cost and procurement. Because RECs can be derived from renewable energy projects located anywhere in the country, there is a greater level of competition among suppliers, which exerts downward pressure on prices. Figure 7, compiled from a very limited sample of publicly available data on large REC purchases, shows that similar to green pricing, REC prices have declined considerably in recent years. ${ }^{26}$ REC prices tend to be lower than utility green pricing premiums, again owing to a greater level of competition among suppliers and the existence of a national marketplace for RECs. In fact, published market data for October 2006 shows a price range of from $0.15 \phi / \mathrm{kWh}$ to $0.9 \phi / \mathrm{kWh}$ for non-solar voluntary REC offers (Table 14).

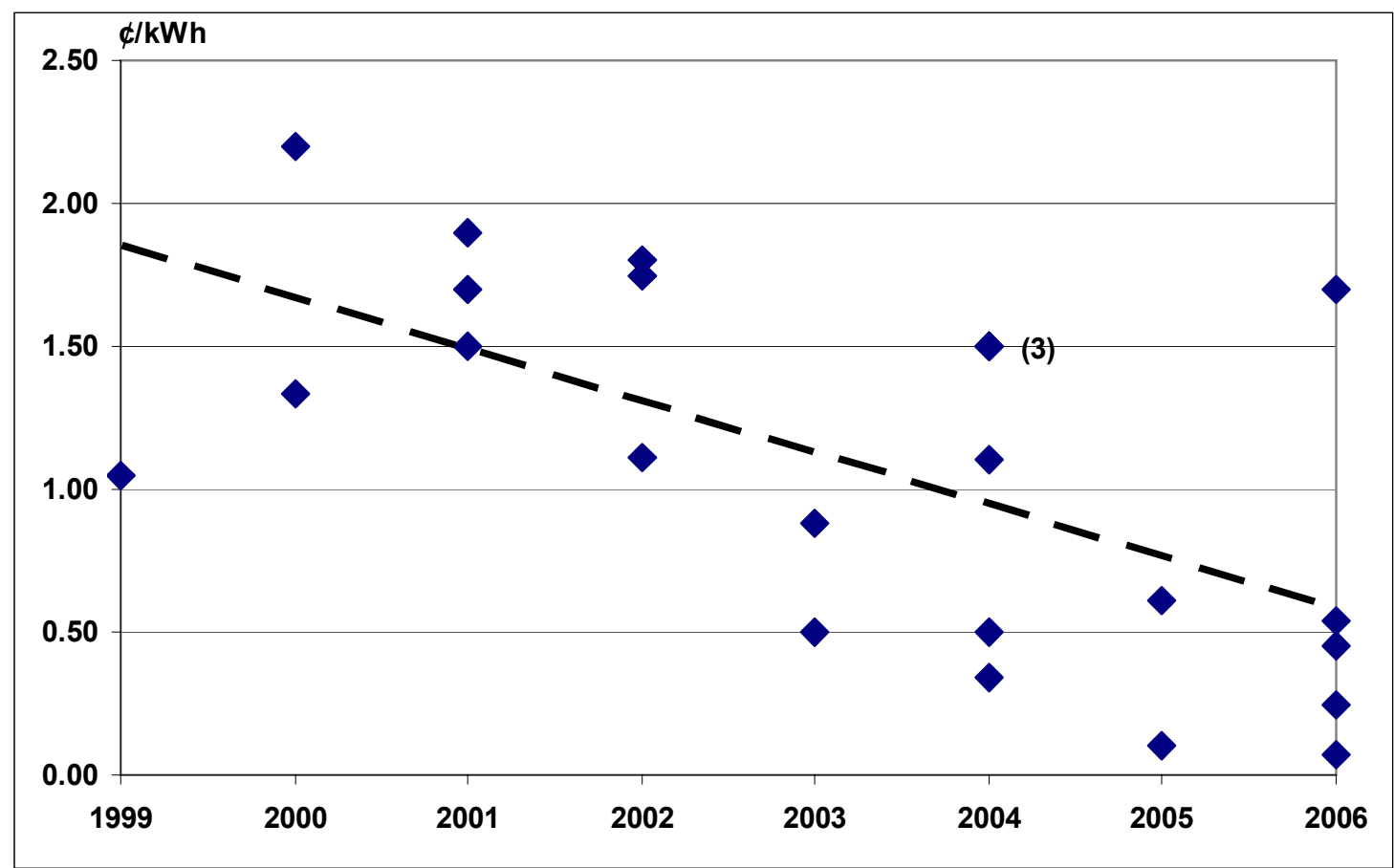

Note: In 2004, there were three publicly announced REC deals priced at $1.50 \phi / \mathrm{kWh}$.

Figure 7: Trend in Green Power Purchase Contract Prices

\footnotetext{
${ }^{26}$ Several caveats must be offered on the price data presented in Figure 7. First, no attempt has been made to control for renewable fuel type, e.g., wind, landfill gas, or small hydro, or for product quality, e.g., products supplied from $100 \%$ "new" projects vs. product blends sourced from new and existing projects. Second, the regional mix of purchases for which price data is available may not be representative of the nation as a whole. The type of buyer, e.g., public agency vs. private company, and the quantity purchased can also be important. In the latter case, customers likely are able to negotiate more favorable pricing for larger purchase amounts. Finally, whether a purchase consists of local/regional RECs or national RECs can affect the price - national RECs are generally more plentiful and available at very low prices whereas customers may face higher prices for local/regional RECs because of more limited supply and sourcing options.
} 
Table 14: Voluntary REC Offers and Pricing, October 2006

\begin{tabular}{ccccccc}
\hline - PRODUCT & - GENERATIOM & -REGION & - TERM & - VOUME (MMW) & - EID & - OFFER \\
\hline NewTRC & wind & National & 2006 & 50,000 & $\$ 1.25$ & $\$ 1.75$ \\
\hline NewTRC & wind & WECC & $2007-2008$ & 25,000 & $\$ 3.00$ & $\$ 4.50$ \\
\hline NewTRC & wind & National & $2007-2008$ & 100,000 & $\$ 1.60$ & $\$ 2.10$ \\
\hline NewTRC & wind & CA & 2008 & 150,000 & $\$ 5.00$ & $\$ 8.00$ \\
\hline NewTRC & geothermal & WECC & $2007-2010$ & 200,000 & $\$ 5.00$ & $\$ 9.00$ \\
\hline NewTRC & biomass & National & 2007 & 50,000 & $\$ 1.00$ & $\$ 1.50$ \\
\hline
\end{tabular}

Source: Evolution Markets Inc., "Monthly Market Update: REC Markets," October 2006.

(http://www.evomarkets.com/resources/index.php?xp1=1\&type=mmu)

Whether REC prices will continue to fall is an open question. Because of global demand pressures, market prices for wind turbines and solar modules have been rising, increasing the cost of some new renewable energy projects. However, costs are also rising for construction of new power plants utilizing conventional fuels, perhaps negating any near-term impact on REC prices. Competition for RECs could also heat up as RPS policies proliferate and compliance requirements ramp up. Nevertheless, REC prices remain low currently and early indications are that 2006 will be another year of significant growth in green power sales. For example, in October 2006, the EPA Green Power Partnership announced that total annual renewable energy purchase commitments among its partners had risen to more than 7 billion $\mathrm{kWh}$, up from about 4 billion $\mathrm{kWh}$ at the end of 2005 . $^{27}$

\section{Utility/Marketer Partnerships}

As noted previously, utility green pricing programs, on average, have achieved participation rates of about $1.5 \%$. And under the most favorable market conditions, competitive green power marketers have garnered about $1 \%$ to $2 \%$ of retail customers. Meanwhile, the most successful green power programs have achieved participation rates of from $5 \%$ to $15 \%$.

In recent years, a number of utilities have turned to partnering with independent, third-party renewable energy marketers to design and promote their green power programs or to enhance the effectiveness of existing programs. Today, more than 25 utilities either voluntarily team with marketers to offer green power options or do so under legal or regulatory requirements. Several states also require default electricity suppliers to offer green power options in conjunction with competitive marketers. These programs provide access to retail green energy products in restructured markets where none may otherwise exist.

A recent review showed that strategic partnerships between utilities and marketers can be an effective approach to marketing green power in both regulated and restructured electricity markets (Bird and Brown, 2006b). Such partnerships leverage the program design, sales, and resource procurement experience of marketers and the utility's service reputation and access to

\footnotetext{
27 “EPA's Green Power Top-25 Announced: Wells Fargo Joins List as Top Corporation,” EPA News Release, October 3, 2006.

http://yosemite.epa.gov/opa/admpress.nsf/a8f952395381d3968525701c005e65b5/390b6eff78f77da6852571fc00611 971! OpenDocument
} 
customers. In states with competitive electricity markets, partnerships between default suppliers and marketers provide greater choices for residential and small commercial customers, who may otherwise be hesitant to switch suppliers. Partnerships also create greater incentives for success because marketers have a vested financial interest in maximizing customer participation and green power sales.

\section{Interaction with Energy and Environmental Policies}

\section{Renewable Portfolio Standards}

Voluntary green power markets represent a market-based mechanism for increasing renewable energy development through consumer demand while renewable portfolio standards (RPS) represent a policy mandate. ${ }^{28}$ An RPS requires electricity providers to supply a certain quantity or percentage of their delivered energy from renewable energy sources. RPS policies have been adopted in 21 states and the District of Columbia through legislative action, regulatory order, or ballot initiative.

Depending on the design, an RPS policy can either support or limit the voluntary market for renewable energy. Most important is whether or not renewable electricity used for voluntary green power programs should be counted towards the RPS requirement. By counting voluntary purchases, suppliers may have an easier time meeting the RPS requirements and at a lower overall cost. On the other hand, counting voluntary market sales toward RPS compliance undermines one of the fundamental tenets of these markets, which is that voluntary purchases support renewable energy development that is additional to policy mandates for which all customers share the cost.

Most states with an RPS policy have determined that voluntary green power purchases should not be counted toward RPS compliance. For example, Minnesota statutes require the state's utilities to both offer their customers the opportunity to purchase some or all of their energy from renewable energy sources and to make good-faith efforts to generate or otherwise secure enough electricity from qualifying renewable energy technologies to represent $10 \%$ of total retail electric sales by 2015. In considering how to integrate these two policies, the Minnesota Public Utilities Commission determined that counting green pricing sales toward the renewable energy objectives was not consistent with the public interest or other state energy policies that seek to encourage renewable energy development.

However, in Texas, a 2005 law that increased the state's RPS included a section that requires all renewable energy capacity in the state to count toward RPS compliance. If implemented, this could have a deleterious effect on voluntary market sales from Texas-based renewable energy projects. Most voluntary market customers expect their purchases to be additional to any policy requirements. In fact, such "additionality" is a primary requirement of the Green-e certification program as well as for membership in the EPA Green Power Partnership.

\footnotetext{
${ }^{28}$ Generally, RPS policies do include some market-based mechanisms, such as requiring renewable energy developers to compete for power supply contracts and employing renewable energy credit trading.
} 
In many cases, voluntary green power programs have preceded establishment of a state RPS mandate. Voluntary green power markets have raised public awareness of and support for renewables, provided utilities with experience in the operation and grid integration of renewable energy technologies, and built new constituencies for renewable energy among rural landowners and farmers, all of which have provided key arguments and support for RPS policy adoption. Many renewable energy project developers support continuation of both markets to provide revenue options and reduce the risk of holding unutilized renewable energy generation. ${ }^{29}$

\section{Carbon Emissions Policies}

While renewable energy purchases provide a number of benefits, many consumer purchases have been motivated, at least in part, by their greenhouse gas benefits. Currently, green power purchasing is one accessible and relatively easy way for consumers, companies and organizations to reduce their carbon footprints. Most utilities and marketers that offer green power promote their products by touting the greenhouse gas benefits. Likewise, many purchasers point to the carbon reduction benefits of their green power purchases in news releases and other promotional materials.

Carbon control policies have the potential to substantially impact voluntary markets for renewable energy. Carbon regulation is now emerging in the Northeast under the Regional Greenhouse Gas Initiative (RGGI) and in California as a result of recently adopted legislation (AB32). There is increased discussion about carbon regulation at the national level as well. Both RGGI and California plan to implement cap-and-trade programs to achieve carbon reductions, similar to the successful national sulfur dioxide $\left(\mathrm{SO}_{2}\right)$ cap-and-trade system developed under the Clean Air Act Amendments of 1990 to address acid rain.

Under a carbon cap-and-trade program, the ability for renewable energy generation sources to affect carbon emissions levels will depend on the program design; for example, whether renewable generation sources are allocated allowances that can be retired or are otherwise considered in setting the level of the cap. This, in turn, will impact the claims that renewable energy generators and marketers can make with respect to carbon reductions. If cap-and-trade programs are designed such that voluntary green power purchases do not lead to overall carbon emission reductions, this will limit the greenhouse gas benefit claims of purchasers and pose a challenge for green power marketers.

The design of emerging regulatory programs to reduce carbon emissions will thus have important implications for the operation and perhaps even the viability of voluntary renewable energy markets in the future. ${ }^{30}$ In the meantime, a growing number of companies and organizations are marketing carbon-offset products to help consumers reduce their carbon footprints, covering everything from offsetting the carbon emissions associated with personal car and air travel to "greening" the electricity used at business conferences. Carbon offsets face many of the same issues and challenges of definition, verification and certification as green

\footnotetext{
29 "Supplying Green Power in Compliance and Voluntary Markets,” Presentation by Barrett Stambler, PPM Energy, at the Tenth National Green Power Marketing Conference, Austin, Texas, October 26, 2005. http://www.eere.energy.gov/greenpower/conference/10gpmc05/stambler.pdf.

${ }^{30} \mathrm{~A}$ forthcoming NREL report will provide a detailed examination of the implications of emerging carbon markets and policies on voluntary renewable energy markets.
} 
power; in fact verification of carbon offsets is more challenging than for green power because of the wide array of offset activities.

Carbon-offset products can be both a threat and opportunity for green power. If offset products include renewable energy as a component, then this market will provide a stimulus for renewable energy development. On the other hand, there are any number of alternative measures that could qualify as carbon offsets, which creates competition for green power as a carbon reduction strategy. ${ }^{31}$

\section{Is Green Power Simply an Evolutionary Step in Renewable Energy Development?}

Finally, when, if ever, does premium-priced green power become unnecessary? Most new green power today is being supplied by wind energy, which is arguably becoming more widely cost competitive with conventional electricity supplies. Should customers continue to pay a premium for green power once it becomes cost competitive? For example, when Minnkota Power Cooperative, which serves 11 distribution cooperatives in Minnesota and North Dakota, recently lowered the premium charged for its Infinity Wind Energy program from $1.5 \phi / \mathrm{kWh}$ to $0.5 \phi / \mathrm{kWh}$, one distribution utility - Nodak Electric - decided to drop the premium-priced program altogether and include the wind energy in base rates. ${ }^{32}$

Some argue that green pricing should be focused on renewable energy technologies that are furthest from market competitiveness and thus need additional financial support, such as solar energy. And many believe that an RPS is a fair and effective policy for accelerating renewable energy development and sharing the cost of that development among all consumers. On the other hand, there are an abundance of customers who want to support renewable energy beyond the minimum deployment levels called for in an RPS, which is typically from $10 \%$ to $20 \%$ of total electricity supply. For example, many customers, including large Fortune 500 companies, choose to offset $100 \%$ of their power usage with green power and are willing to pay more for that opportunity.

Voluntary green power markets continue to play an important role in educating the public about renewable energy sources and options. And there is ample evidence that voluntary markets encourage new renewable energy development as well as support and build on RPS markets by providing an additional market outlet and revenue source for renewable energy project output.

\footnotetext{
${ }^{31}$ The ClimateBiz Web site notes that "there are three main types of projects that produce offsets: projects that prevent the release of $\mathrm{CO}_{2}$, projects that reduce non- $\mathrm{CO}_{2}$ greenhouse gases, and projects that sequester carbon in vegetation or soil."

See http://www.climatebiz.com/sections/backgrounder detail.cfm?UseKeyword=Carbon\%20Offsets

32 See "Wind subscription cost eliminated" in Nodak Neighbor customer newsletter (July/August 2006). http://www.nodakelectric.com/pdf/JulyAug\%202006\%20NN.pdf
} 


\section{Conclusions and Observations}

The green power market continues to exhibit strong growth and provide an important demanddriven stimulus for renewable energy development. Green power markets provide an additional revenue stream for renewable energy projects, and raise consumer awareness of the benefits of renewable energy. Based on this review, we have identified the following market trends:

- In 2005, retail sales of renewable energy in voluntary purchase markets totaled 8.5 billion $\mathrm{kWh}$, representing a capacity equivalent of 2,500 MW of renewable energy, including 2,000 MW from new renewable energy sources. The latter figure corresponds to $22 \%$ of the total renewable energy capacity additions since 1997; thus, green power purchases are providing support for a significant fraction of new renewable energy projects, nationally.

- Wind energy provided $61 \%$ of green power sales in 2005 , followed by biomass energy sources (27\%), hydropower (6\%), geothermal (5\%), and solar (1\%).

- Total market sales increased by $37 \%$ in 2005 . Much of this growth was driven by REC sales to nonresidential consumers, which more than doubled during 2005. As a result, commercial and institutional REC markets now represent nearly half of total green power market sales, surpassing sales in competitive electricity markets and utility green pricing programs.

- Utility green pricing programs in regulated electricity markets continued to show steady growth, with sales increasing by $33 \%$ in 2005 . However, a relatively small number of utility programs continue to dominate sales and customer numbers. This suggests that stronger performance is possible with effective program design and implementation, and dedicated marketing strategies but also that many programs are not achieving their full potential.

- Competitive markets continued to exhibit volatility, with sales declining nearly $20 \%$ during 2005. Difficulties posed by market rules and conditions, as well as the continuing challenge of convincing customers to switch electricity providers, has led marketers to shift away from delivered renewable electricity products toward marketing REC products as well as to pursue partnerships with default suppliers to supply and market green power. Despite the losses in competitive markets, programs in which marketers have teamed with default suppliers doubled in terms of both sales and customers during 2005, showing that utility/marketer partnerships hold promise for future growth.

- Overall, the number of customers purchasing green power increased modestly, with gains in utility green pricing programs and utility/marketer programs offsetting losses elsewhere in competitive retail markets.

- In 2005 , for the first time, a majority of green power sales (65\%) were made to nonresidential customers. Overall, nonresidential sales doubled while sales to residential customers declined by $14 \%$ because of losses in competitive retail markets. The growing dominance of nonresidential sales is a departure from the early history of green power markets when most products and programs were oriented toward residential customers. Looking forward, demand by the nonresidential sector appears to be increasing and will likely continue to drive future voluntary market growth.

- Utility green pricing premiums have continued to fall, owing to a combination of higher prices of conventional generation fuels and lower renewable resource costs. In fact, a number of programs that exempt customers from fossil fuel costs saw the price of green power fall below conventional electricity prices, which necessitated customer waiting lists. Wholesale REC prices have also fallen in some markets, contributing to REC sales growth. 


\section{References}

Bird, L. and E. Brown, 2006a. Trends in Utility Green Pricing Programs (2005), NREL/TP-62040777 Golden, CO: National Renewable Energy Laboratory, October.

http://www.nrel.gov/docs/fy07osti/40777.pdf

Bird, L. and E. Brown, 2006b. Utility-Marketer Partnerships: An Effective Strategy for Marketing Green Power? NREL/TP-620-39730 Golden, CO: National Renewable Energy Laboratory, April. http://www.nrel.gov/docs/fy06osti/39730.pdf

Bird, L. and E. Brown, 2005. Trends in Utility Green Pricing Programs (2004), NREL/TP-62038800 Golden, CO: National Renewable Energy Laboratory, September. http://www.eere.energy.gov/greenpower/resources/pdfs/38800.pdf

Bird, L. and K. Cardinal, 2004. Trends in Utility Green Pricing Programs (2003), NREL/TP620-36833 Golden, CO: National Renewable Energy Laboratory, September. http://www.eere.energy.gov/greenpower/pdfs/36833.pdf

Bird, L. and B. Swezey, 2005a. Green Power Marketing in the United States: A Status Report (Eighth Edition), NREL/TP-620-38994. Golden, CO: National Renewable Energy Laboratory, October.

http://www.eere.energy.gov/greenpower/resources/pdfs/38994.pdf

Bird, L. and B. Swezey, 2005b. "Estimates of New Renewable Energy Capacity Serving U.S. Green Power Markets” National Renewable Energy Laboratory, September. http://www.eere.energy.gov/greenpower/resources/tables/new gp cap.shtml

Bird, L. and B. Swezey, 2004. Green Power Marketing in the United States: A Status Report (Seventh Edition), NREL/TP-620-36823. Golden, CO: National Renewable Energy Laboratory, September.

http://www.eere.energy.gov/greenpower/pdfs/36823.pdf

Bird, L. and B. Swezey, 2003. Green Power Marketing in the United States: A Status Report $\left(6^{\text {th }}\right.$ Edition), NREL/TP-620-35119. Golden, CO: National Renewable Energy Laboratory, October. http://www.eere.energy.gov/greenpower/resources/pdfs/35119.pdf

Center for Resource Solutions, 2002. Green-e Verification Report, 2001 http://www.greene.org/what is/standard/verification.html

Center for Resource Solutions, 2001. Green-e Verification Report, 2000 http://www.greene.org/what_is/standard/verification.html

Electric Power Research Institute (EPRI) and U.S. Department of Energy (DOE), 1997. Renewable Energy Technology Characterizations, TR-109496, December.

Holt, E.A., and M. Holt, 2004. Green Pricing Resource Guide (2nd Edition), Ed Holt \& Associates, Inc., Harpswell, Maine. Prepared for the American Wind Energy Association, 
Washington DC, September.

http://www.awea.org/greenpower/greenPricingResourceGuide040726.pdf

Swezey, B. and L. Bird, 2001. Utility Green Pricing Programs: What Defines Success? NREL/TP-620-29831. Golden, CO: National Renewable Energy Laboratory, August.

http://www.eere.energy.gov/greenpower/29831.pdf

Swezey, B. and L. Bird, 2000. Green Power Marketing in the United States: A Status Report $\left(5^{\text {th }}\right.$ Edition), NREL/TP-620-28738. Golden, CO: National Renewable Energy Laboratory, August. http://www.eere.energy.gov/greenpower/resources/pdfs/28738.pdf

Swezey, B. and L. Bird, 1999. Information Brief on Green Power Marketing, 4th Edition. NREL/TP-620-26901. Golden: CO: National Renewable Energy Laboratory, August. http://www.eere.energy.gov/greenpower/resources/pdfs/26901.pdf

U.S. Energy Information Administration (EIA), 2006a. Renewable Energy Annual 2004, DOE/EIA, June.

http://www.eia.doe.gov/cneaf/solar.renewables/page/rea data/rea sum.html

U.S. Energy Information Administration (EIA), 2006b. Annual Energy Outlook 2006, DOE/EIA, DOE/EIA-0383(2006), February.

http://www.eia.doe.gov/oiaf/aeo/index.html

Wiser, R. and S. Olsen, with L. Bird and B. Swezey, 2004. Utility Green Pricing Programs: A Statistical Analysis of Program Effectiveness. Report prepared by Lawrence Berkeley National Laboratory, Berkeley, California, February. LBNL-54437.

http://www.eere.energy.gov/greenpower/resources/pdfs/lbnl_54437.pdf 


\section{Appendix A}

Estimates of New Renewable Energy Capacity Serving Green Power Markets, 2000-2004

Prior to 2005, estimates of the capacity serving green power markets were made based on renewable energy projects used to serve green power programs, rather than derived from renewable energy sales. Therefore, the 2005 estimated capacity is not directly comparable to capacity estimates from previous years. However, the two approaches yield relatively consistent results.

Bird and Swezey (2005b) provide details on the derivation of capacity estimates for years 2004 and earlier. Table A-1 presents estimates of the cumulative new renewable energy capacity serving voluntary markets from 2000 to 2004. A brief description of the methodology is included below.

Table A-1: Estimated Cumulative New Renewable Energy Capacity Supplying Green Power Markets, 2000-2004* (megawatts)

\begin{tabular}{|l|c|c|c|c|c|}
\hline Market & $\mathbf{2 0 0 0}$ & $\mathbf{2 0 0 1}$ & $\mathbf{2 0 0 2}$ & $\mathbf{2 0 0 3}$ & $\mathbf{2 0 0 4}$ \\
\hline Utility Green Pricing & 77 & 221 & 279 & 510 & 706 \\
\hline Competitive Markets/RECs & 90 & 542 & 695 & 1,126 & 1,528 \\
\hline Total $^{* *}$ & $\mathbf{1 6 7}$ & $\mathbf{7 6 4}$ & $\mathbf{9 7 4}$ & $\mathbf{1 , 6 3 6}$ & $\mathbf{2 , 2 3 3}$ \\
\hline
\end{tabular}

*Data not directly comparable with Table 4.

**Totals may not add due to rounding.

Source: Bird and Swezey (2005b).

The 2004 and earlier estimates of capacity serving green power markets focus on new renewable resources used to serve green power customers. New renewable resources are defined as projects or portions of projects built specifically to serve green power customers or recently constructed projects that are used to supply green power customers and meet the regional Green-e standards for new renewables. The estimates do not include pre-existing renewable energy projects used for green power supply or capacity used to meet state RPS requirements or other renewable energy mandates.

These estimates generally include the entire capacity of a given renewable energy project irrespective of whether the output has been fully subscribed by green power purchasers, e.g., if a utility or developer completed a project before the entire output was sold to prospective customers. Thus, the estimates may include some capacity for which a green power buyer was not yet secured. However, in cases where a portion of a project is used to meet a renewable energy mandate, only the remainder of the project is counted. 


\section{Appendix B}

Table B-1: Top 25 Purchasers in the U.S. EPA Green Power Partnership, September 2006

\begin{tabular}{|c|c|c|c|c|c|}
\hline Rank & Organization & $\begin{array}{l}\text { Green Power } \\
\text { Usage (kWh) }\end{array}$ & $\begin{array}{l}\text { \% of Total } \\
\text { Electricity }\end{array}$ & Organization Type & Resources \\
\hline 1 & U.S. Air Force & $1,043,558,000$ & $11 \%$ & Government (Federal) & $\begin{array}{l}\text { Biomass, Geothermal, } \\
\text { Wind }\end{array}$ \\
\hline 2 & Wells Fargo \& Co. & $550,000,000$ & $42 \%$ & Banking & Wind \\
\hline 3 & $\begin{array}{c}\text { Whole Foods } \\
\text { Market }\end{array}$ & $463,128,000$ & $100 \%$ & Retail & $\begin{array}{l}\text { Biomass, Geothermal, } \\
\text { Small-hydro, Solar, Wind }\end{array}$ \\
\hline 4 & U.S. EPA & $329,880,185$ & $100 \%$ & Government (Federal) & $\begin{array}{l}\text { Biogas, Biomass, } \\
\text { Geothermal, Wind }\end{array}$ \\
\hline 5 & $\begin{array}{c}\text { Johnson \& } \\
\text { Johnson }\end{array}$ & $306,418,000$ & $30 \%$ & Manufacturing & $\begin{array}{l}\text { Biomass, Small-hydro, } \\
\text { Solar, Wind }\end{array}$ \\
\hline 6 & Starbucks & $185,000,000$ & $20 \%$ & Food, Food Services & Wind \\
\hline 7 & DuPont Co. & $170,000,000$ & $4 \%$ & Chemical & Biomass \\
\hline 8 & U.S. DOE & $165,063,000$ & $3 \%$ & Government (Federal) & $\begin{array}{l}\text { Biomass, Geothermal, } \\
\text { Wind }\end{array}$ \\
\hline 9 & Vail Resorts & $152,000,000$ & $100 \%$ & Tourism, Recreation & Wind \\
\hline 10 & HSBC N.A. & $124,544,000$ & $35 \%$ & Banking & Wind \\
\hline 11 & $\begin{array}{l}\text { University of } \\
\text { Pennsylvania }\end{array}$ & $112,000,000$ & $29 \%$ & Education (Higher) & Wind \\
\hline 12 & World Bank Group & $106,762,000$ & $100 \%$ & Non-Profit & Wind \\
\hline 13 & IBM Corp. & $93,725,000$ & $3 \%$ & Manufacturing & Solar, Wind \\
\hline 14 & Sprint Nextel & $87,600,000$ & $47 \%$ & Telecommunications & Wind \\
\hline 15 & Safeway Inc. & $87,000,000$ & $2 \%$ & Retail & Wind \\
\hline 16 & $\begin{array}{c}\text { Commonwealth of } \\
\text { Pennsylvania }\end{array}$ & $79,801,000$ & $8 \%$ & Government (State) & Wind \\
\hline 17 & $\begin{array}{l}\text { The Tower } \\
\text { Companies }\end{array}$ & $79,000,000$ & $100 \%$ & Real Estate & Wind \\
\hline 18 & U.S. GSA & $76,366,800$ & $33 \%$ & Government (Federal) & Biogas, Wind \\
\hline 19 & \begin{tabular}{|c|} 
California State \\
University System
\end{tabular} & $75,435,000$ & $13 \%$ & Education (Higher) & $\begin{array}{l}\text { Biomass, Geothermal, } \\
\text { Wind }\end{array}$ \\
\hline 20 & Staples & $71,600,588$ & $14 \%$ & Retail & $\begin{array}{l}\text { Biogas, Biomass, Solar, } \\
\text { Wind }\end{array}$ \\
\hline 21 & City of Austin & $65,454,000$ & $54 \%$ & Government (Muni) & Biogas, Wind \\
\hline 22 & City of San Diego & $65,400,000$ & $25 \%$ & Government (Muni) & $\begin{array}{l}\text { Biogas, small-hydro, } \\
\text { solar }\end{array}$ \\
\hline 23 & NatureWorks LLC & $59,000,000$ & $59 \%$ & Manufacturing & Wind \\
\hline 24 & FedEx Kinko's & $54,690,033$ & $20 \%$ & Retail & Various \\
\hline 25 & Duke University & $54,075,000$ & $31 \%$ & Education (Higher) & Small-hydro, Wind \\
\hline
\end{tabular}

Source: U.S. EPA Green Power Partnership http://www.epa.gov/greenpower/partners/top25.htm 
Appendix C

Table C-1: Estimated U.S. Green Power Customers by State, 2003 and 2004

\begin{tabular}{|c|c|c|c|c|c|}
\hline \multirow[b]{3}{*}{ State } & \multirow{3}{*}{$\begin{array}{l}\text { Electric Industry } \\
\text { Participants } \\
2004^{\mathrm{a}} \\
\end{array}$} & \multicolumn{3}{|c|}{ Participating Customers } & \multirow{3}{*}{$\begin{array}{l}2003 \\
\text { Total } \\
\end{array}$} \\
\hline & & \multicolumn{3}{|c|}{$2004^{p}$} & \\
\hline & & Residential & Nonresidential & Total & \\
\hline Alabama & 2 & 735 & 20 & 755 & \\
\hline \multicolumn{6}{|l|}{ Alaska } \\
\hline Arizona & 3 & 5,701 & 91 & 5,792 & 5,934 \\
\hline \multicolumn{6}{|l|}{ Arkansas } \\
\hline California & 12 & 59,158 & 2,932 & 62,090 & 62,279 \\
\hline Colorado & 23 & 39,389 & 777 & 40,166 & 44,194 \\
\hline \multicolumn{6}{|l|}{ Connecticut } \\
\hline Delaware & 2 & 8 & 7 & 15 & \\
\hline District of Columbia & 2 & 4,994 & 228 & 5,222 & 4,824 \\
\hline Florida & 3 & 11,053 & 23 & 11,076 & 218 \\
\hline Georgia & 14 & 3,223 & 18 & 3,241 & 3,895 \\
\hline Hawaii & 3 & 3,965 & 40 & 4,005 & 3,579 \\
\hline Idaho & 6 & 4,173 & 110 & 4,283 & 2,508 \\
\hline Illinois & 3 & 31 & & 31 & 8 \\
\hline Indiana & 8 & 1,313 & 26 & 1,339 & 1,091 \\
\hline Iowa & 50 & 7,239 & 74 & 7,313 & 5,785 \\
\hline \multicolumn{6}{|l|}{ Kansas } \\
\hline Kentucky & 11 & 502 & 11 & 513 & 118 \\
\hline Maine & 1 & & 8 & 8 & 5 \\
\hline Maryland & 2 & 14,985 & 193 & 15,178 & 14,356 \\
\hline Massachusetts & 3 & 2,741 & 125 & 2,866 & 1 \\
\hline Michigan & 7 & 1,319 & 57 & 1,376 & 1,346 \\
\hline Minnesota & 90 & 22,803 & 255 & 23,058 & 20,255 \\
\hline Mississippi & 2 & 79 & 2 & 81 & 7 \\
\hline Missouri & 7 & 392 & 6 & 398 & 261 \\
\hline Montana & 6 & 398 & 9 & 407 & 49 \\
\hline Nebraska & 5 & 4,017 & 54 & 4,071 & 4,171 \\
\hline Nevada & 2 & 493 & 5 & 498 & 285 \\
\hline \multicolumn{6}{|l|}{ New Hampshire } \\
\hline New Jersey & 3 & 1,575 & 336 & 1,911 & 1,816 \\
\hline New Mexico & 7 & 8,031 & 430 & 8,461 & 5,774 \\
\hline New York & 3 & 1,272 & 213 & 1,485 & 134 \\
\hline North Carolina & 15 & 6,024 & 242 & 6,266 & 3,913 \\
\hline North Dakota & 11 & 4,666 & 21 & 4,687 & 1,792 \\
\hline Ohio & 3 & 407,051 & 47,458 & 454,509 & 428,849 \\
\hline Oklahoma & 7 & 9,342 & 195 & 9,537 & 6,758 \\
\hline Oregon & 12 & 52,655 & 1,247 & 53,902 & 42,139 \\
\hline Pennsylvania & 3 & 36,299 & 29 & 36,328 & 74,676 \\
\hline Rhode Island & 2 & 1,469 & 36 & 1,505 & \\
\hline South Carolina & 8 & 1,842 & 234 & 2,076 & 1,725 \\
\hline South Dakota & 8 & 460 & 13 & 473 & 624 \\
\hline Tennessee & 1 & 6,216 & 307 & 6,523 & 1 \\
\hline Texas & 4 & 62,331 & 6,049 & 68,380 & 68,611 \\
\hline Utah & 3 & 13,660 & 407 & 14,067 & 15,480 \\
\hline Vermont & 1 & 868 & 31 & 899 & \\
\hline Virginia & 2 & 3,418 & 20 & 3,438 & 4,639 \\
\hline Washington & 19 & 27,554 & 555 & 28,109 & 16,858 \\
\hline \multicolumn{6}{|l|}{ West Virginia } \\
\hline Wisconsin & 56 & 28,607 & 592 & 29,199 & 26,595 \\
\hline Wyoming & 6 & 2,743 & 53 & 2,796 & 1,573 \\
\hline Total & 403 & 864,794 & 63,539 & 928,333 & 877,126 \\
\hline \multicolumn{6}{|c|}{$\begin{array}{l}\text { Includes entities with green pricing programs in more than one state. } \\
\mathrm{P}=\text { Preliminary }\end{array}$} \\
\hline
\end{tabular}




\section{Appendix D}

Table D-1: Utilities Offering Green Pricing Programs in 2005

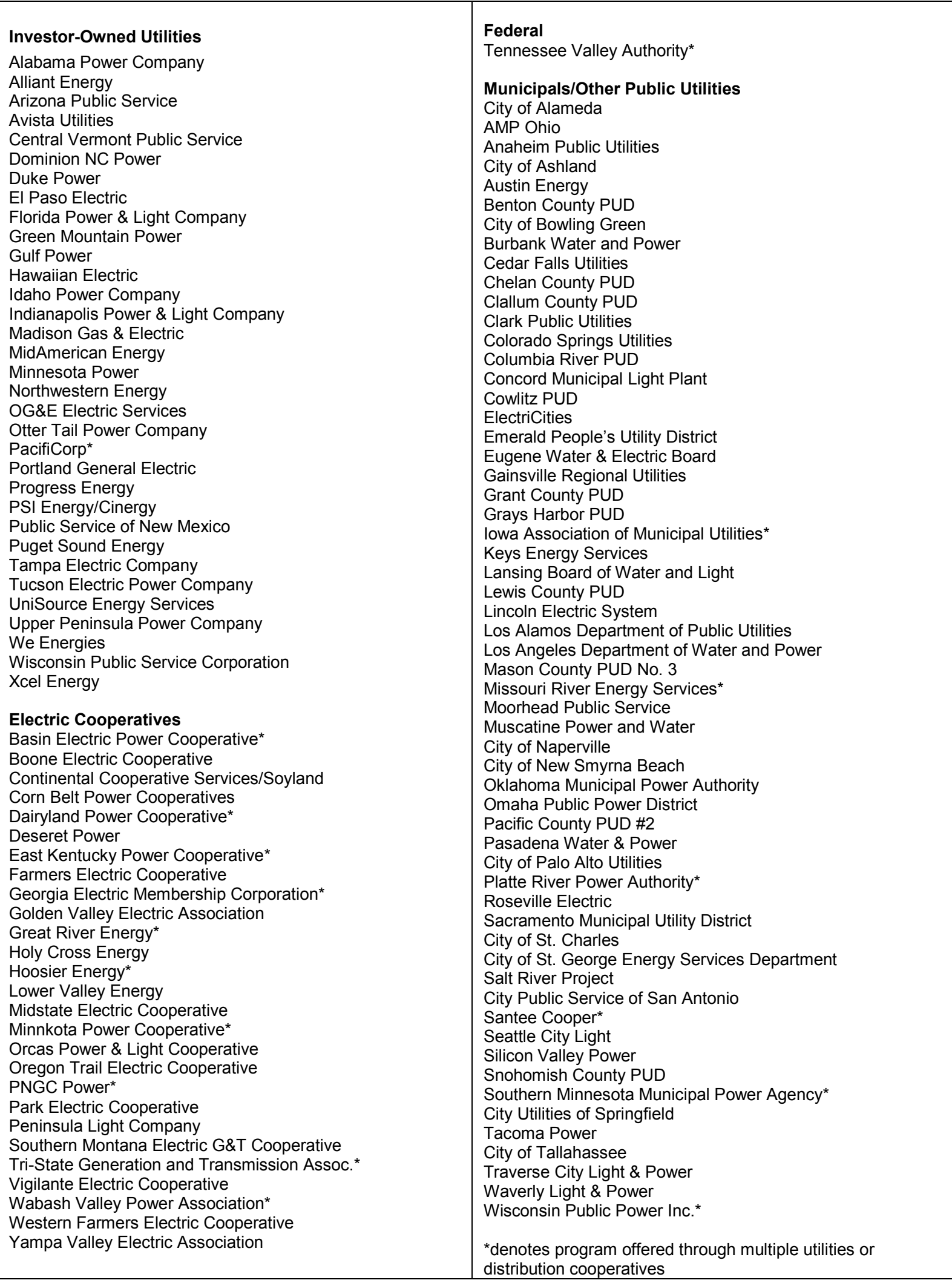




\section{Appendix E}

Table E-1: Utility Green Pricing Programs, November 2006

\begin{tabular}{|c|c|c|c|c|c|}
\hline State & Utility Name & Program Name & Type & Start Date & Premium \\
\hline AL & $\begin{array}{l}\text { Alabama Electric Cooperative: Central } \\
\text { Alabama Electric Cooperative, Coosa } \\
\text { Valley Electric Cooperative, Dixie } \\
\text { Electric Cooperative, South Alabama } \\
\text { Electric Cooperative, Southern Pine } \\
\text { Electric Cooperative, Tallapoosa River } \\
\text { Electric Cooperative, Wiregrass Electric } \\
\text { Cooperative }\end{array}$ & Green Power Choice & landfill gas & 2006 & $2.0 \phi / \mathrm{kWh}$ \\
\hline AL & Alabama Power Company & $\begin{array}{l}\text { Renewable Energy } \\
\text { Rate }\end{array}$ & $\begin{array}{l}\text { biomass co- } \\
\text { firing (wood) }\end{array}$ & $2003 / 2000$ & $6.0 \phi / \mathrm{kWh}$ \\
\hline $\mathrm{AL}$ & $\begin{array}{l}\text { TVA: City of Athens Electric Department, } \\
\text { Cullman Electric Coop, Cullman Power } \\
\text { Board, Decator Utilities, Florence } \\
\text { Utilities, Hartselle Utilities, Huntsville, } \\
\text { Joe Wheeler EMC, Muscle Shoals } \\
\text { Electric Board, Scottsboro Electric Power } \\
\text { Board, Sheffield Utilities, Tuscumbia } \\
\text { Electric Department }\end{array}$ & Green Power Switch & $\begin{array}{l}\text { landfill gas, PV, } \\
\text { wind }\end{array}$ & 2000 & $2.67 \phi / k W h$ \\
\hline AK & Golden Valley Electric Association & $\begin{array}{l}\text { Sustainable Natural } \\
\text { Alternative Power } \\
\text { (SNAP) }\end{array}$ & $\begin{array}{l}\text { various local } \\
\text { projects }\end{array}$ & 2005 & Contribution \\
\hline$A Z$ & Arizona Public Service & $\begin{array}{l}\text { APS Solar Partners } \\
\text { Program }\end{array}$ & central PV & 1997 & $17.6 \phi / \mathrm{kWh}$ \\
\hline$A Z$ & Salt River Project & EarthWise Energy & $\begin{array}{l}\text { central PV, } \\
\text { wind, landfill } \\
\text { gas, small } \\
\text { hydro, } \\
\text { geothermal }\end{array}$ & $1998 / 2001$ & $3.0 \phi / \mathrm{kWh}$ \\
\hline$A Z$ & $\begin{array}{l}\text { Tri-State Generation \& Transmission: } \\
\text { Columbus Electric Cooperative, Inc. }\end{array}$ & $\frac{\text { Renewable Resource }}{\text { Power Service }}$ & wind, hydro & 2001 & $1.25 \phi / \mathrm{kWh}$ \\
\hline$A Z$ & Tucson Electric & GreenWatts & landfill gas, PV & 2000 & $10 \phi / \mathrm{kWh}$ \\
\hline$A Z$ & UniSource Energy Services & GreenWatts & PV & 2004 & $10 \phi / \mathrm{kWh}$ \\
\hline $\mathrm{CA}$ & Anaheim Public Utilities & $\begin{array}{l}\text { Green Power for the } \\
\text { Schools }\end{array}$ & PV & 2002 & Contribution \\
\hline $\mathrm{CA}$ & Anaheim Public Utilities & $\begin{array}{l}\text { Green Power for the } \\
\text { Grid }\end{array}$ & wind, landfill gas & 2002 & $1.5 \phi / \mathrm{kWh}$ \\
\hline $\mathrm{CA}$ & Burbank Water and Power & Clean Green Support & various & 2001 & $1.0 \phi / \mathrm{kWh}$ \\
\hline $\mathrm{CA}$ & $\begin{array}{l}\text { Los Angeles Department of Water and } \\
\text { Power }\end{array}$ & $\begin{array}{l}\text { Green Power for a } \\
\text { Green LA }\end{array}$ & wind, landfill gas & 1999 & $3.0 \phi / \mathrm{kWh}$ \\
\hline $\mathrm{CA}$ & PacifiCorp: Pacific Power & Blue Sky Block & wind & 2000 & $1.95 \phi / \mathrm{kWh}$ \\
\hline $\mathrm{CA}$ & $\begin{array}{l}\text { Palo Alto Utilities/3 Phases Energy } \\
\text { Services }\end{array}$ & Palo Alto Green & wind, PV & $2003 / 2000$ & $1.5 \phi / \mathrm{kWh}$ \\
\hline CA & Pasadena Water \& Power & $\underline{\text { Green Power }}$ & wind & 2003 & $2.5 \phi / \mathrm{kWh}$ \\
\hline $\mathrm{CA}$ & Roseville Electric & Green Roseville & wind, PV & 2005 & $1.5 \phi / \mathrm{kWh}$ \\
\hline $\mathrm{CA}$ & Sacramento Municipal Utility District & Greenergy & $\begin{array}{l}\text { wind, landfill } \\
\text { gas, hydro, PV }\end{array}$ & 1997 & $\begin{array}{l}\text { 1.0ф/kWh or } \\
\$ 6 / \mathrm{month}\end{array}$ \\
\hline $\mathrm{CA}$ & $\begin{array}{l}\text { Silicon Valley Power / } 3 \text { Phases Energy } \\
\underline{\text { Services }}\end{array}$ & $\begin{array}{l}\text { Santa Clara Green } \\
\text { Power }\end{array}$ & wind, PV & 2004 & $1.5 \phi / \mathrm{kWh}$ \\
\hline
\end{tabular}




\begin{tabular}{|c|c|c|c|c|c|}
\hline State & Utility Name & Program Name & Type & Start Date & Premium \\
\hline $\mathrm{CO}$ & Colorado Springs Utilities & Green Power & wind & 1999 & $3.0 \phi / \mathrm{kWh}$ \\
\hline $\mathrm{CO}$ & Holy Cross Energy & $\begin{array}{l}\text { Local Renewable } \\
\text { Energy Pool }\end{array}$ & small hydro, PV & 2002 & $2.33 \phi / \mathrm{kWh}$ \\
\hline $\mathrm{CO}$ & Holy Cross Energy & Wind Power Pioneers & wind & 1998 & $1.5 \phi / \mathrm{kWh}$ \\
\hline $\mathrm{CO}$ & $\begin{array}{l}\text { Platte River Power Authority: Estes Park, } \\
\text { Fort Collins Utilities, Longmont Power \& } \\
\underline{\text { Communications, Loveland Water \& }} \\
\underline{\text { Power }}\end{array}$ & Wind Energy Premium & wind & 1999 & $\begin{array}{l}1.0 \phi / \mathrm{kWh}- \\
2.5 \phi / \mathrm{kWh}\end{array}$ \\
\hline $\mathrm{CO}$ & 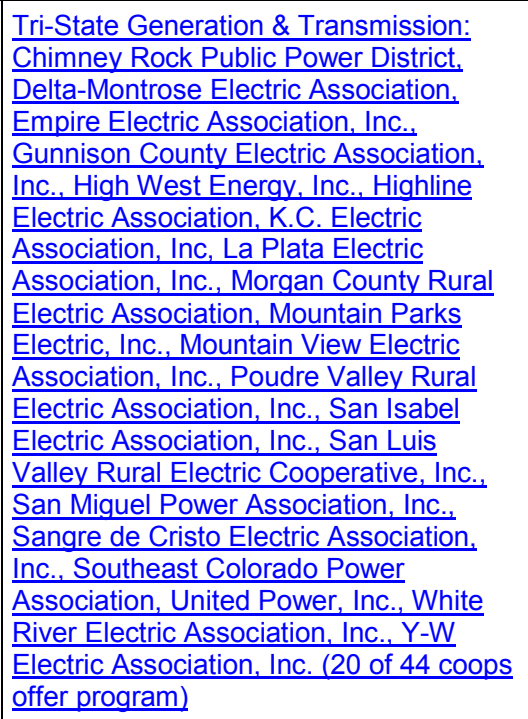 & $\frac{\text { Renewable Resource }}{\text { Power Service }}$ & wind, hydro & 1998 & $1.25 \phi / \mathrm{kWh}$ \\
\hline $\mathrm{CO}$ & Xcel Energy & $\begin{array}{l}\text { Renewable Energy } \\
\text { Trust }\end{array}$ & PV & 1993 & Contribution \\
\hline $\mathrm{CO}$ & Xcel Energy & WindSource & wind & 1997 & $-0.67 \phi / \mathrm{kWh}$ \\
\hline $\mathrm{CO}$ & Yampa Valley Electric Association & Wind Energy Program & wind & 1999 & $3.0 \phi / \mathrm{kWh}$ \\
\hline $\mathrm{DE}$ & Delaware Electric Cooperative & $\begin{array}{l}\text { Renewable Energy } \\
\text { Rider }\end{array}$ & landfill gas & 2006 & $0.2 \phi / \mathrm{kWh}$ \\
\hline $\mathrm{FL}$ & $\begin{array}{l}\text { Alabama Electric Cooperative: Gulf } \\
\text { Coast Electric Cooperative }\end{array}$ & Green Power Choice & landfill gas & 2006 & $2.0 \phi / \mathrm{kWh}$ \\
\hline $\mathrm{FL}$ & City of Tallahassee/Sterling Planet & Green for You & biomass, $\mathrm{PV}$ & 2002 & $1.6 \phi / \mathrm{kWh}$ \\
\hline $\mathrm{FL}$ & City of Tallahassee/Sterling Planet & Green for You & PV only & 2002 & $11.6 \phi / \mathrm{kWh}$ \\
\hline $\mathrm{FL}$ & $\begin{array}{l}\text { Florida Power \& Light / Green Mountain } \\
\text { Energy }\end{array}$ & Sunshine Energy & $\begin{array}{l}\text { biomass, wind, } \\
\text { PV }\end{array}$ & 2004 & $0.975 \phi / k W h$ \\
\hline $\mathrm{FL}$ & Gainesville Regional Utilities & GRUgreen Energy & $\begin{array}{l}\text { landfill gas, } \\
\text { wind, PV }\end{array}$ & 2003 & $2.0 \phi / \mathrm{kWh}$ \\
\hline $\mathrm{FL}$ & Keys Energy Services / Sterling Planet & $\begin{array}{l}\text { GO GREEN: USA } \\
\text { Green }\end{array}$ & $\begin{array}{l}\text { wind, } \\
\text { biomass,PV }\end{array}$ & 2004 & $1.60 \phi / \mathrm{kWh}$ \\
\hline $\mathrm{FL}$ & Keys Energy Services / Sterling Planet & $\begin{array}{l}\text { GO GREEN: Florida } \\
\text { Ever Green }\end{array}$ & $\begin{array}{l}\text { solar hot water, } \\
\text { PV, biomass }\end{array}$ & 2004 & $2.75 \phi / \mathrm{kWh}$ \\
\hline $\mathrm{FL}$ & Tampa Electric Company (TECO) & $\begin{array}{l}\frac{\text { Tampa Electric's }}{\text { Renewable Energy }} \\
\text { Program } \\
\end{array}$ & $\begin{array}{l}\text { PV, biomass co- } \\
\text { firing (wood) }\end{array}$ & 2000 & $5.0 \phi / \mathrm{kWh}$ \\
\hline $\mathrm{FL}$ & $\begin{array}{l}\text { Utilities Commission City of New Smyrna } \\
\text { Beach }\end{array}$ & Green Fund & $\begin{array}{l}\text { local PV } \\
\text { projects }\end{array}$ & 1999 & Contribution \\
\hline
\end{tabular}




\begin{tabular}{|c|c|c|c|c|c|}
\hline State & Utility Name & Program Name & Type & Start Date & Premium \\
\hline GA & $\begin{array}{l}\text { Georgia Electric Membership } \\
\text { Corporation (31 of 42 coops offer } \\
\text { program): Altamaha, Amicalola, } \\
\text { Canoochee, Carroll, Cobb, Coastal } \\
\text { Electric, Coweta-Fayette, Diverse Power, } \\
\text { Flint Energies, GreyStone Power, Grady, } \\
\text { Habersham, Hart, Irwin, Jackson, } \\
\frac{\text { Jefferson Energy, Little Ocmulgee, }}{\text { Mitchell, Ocmulgee, Planters, Rayle, }} \\
\text { Sawnee, Slash Pine, Snapping Shoals, } \\
\text { Southern Rivers Energy, Sumter, Three } \\
\text { Notch, Tri-County, Upson, Walton and } \\
\text { Washington EMCs }\end{array}$ & Green Power EMC & $\begin{array}{l}\text { landfill gas, PV } \\
\text { in schools }\end{array}$ & 2001 & $\begin{array}{l}2.0 \phi / \mathrm{kWh}- \\
3.3 \phi / \mathrm{kWh}\end{array}$ \\
\hline GA & Georgia Power & Green Energy & landfill gas & 2006 & $4.5 \phi / \mathrm{kWh}$ \\
\hline GA & $\begin{array}{l}\text { TVA: Blue Ridge Mountain Electric } \\
\text { Membership Corporation, North Georgia } \\
\text { Electric Membership Corporation }\end{array}$ & Green Power Switch & $\begin{array}{l}\text { landfill gas, PV, } \\
\text { wind }\end{array}$ & 2000 & $2.67 \phi / \mathrm{kWh}$ \\
\hline $\mathrm{HI}$ & Hawaiian Electric & Sun Power for Schools & PV in schools & 1997 & Contribution \\
\hline $\mathrm{HI}$ & Kauai Island Utility Cooperative & $\underline{\text { Green Rate }}$ & $\begin{array}{l}\text { distributed } \\
\text { renewable } \\
\text { energy systems }\end{array}$ & TBD & TBD \\
\hline ID & Avista Utilities & Buck-A-Block & wind & 2002 & $0.33 \phi / \mathrm{kWh}$ \\
\hline ID & Idaho Power & Green Power Program & various & 2001 & $0.98 \phi / \mathrm{kWh}$ \\
\hline ID & PacifiCorp: Utah Power & Blue Sky & wind & 2003 & $1.95 \phi / \mathrm{kWh}$ \\
\hline ID & Vigilante Electric Cooperative & $\begin{array}{l}\text { Alternative Renewable } \\
\text { Energy Program }\end{array}$ & wind & 2003 & $1.1 \phi / \mathrm{kWh}$ \\
\hline IL & $\begin{array}{l}\text { CCS/Soyland and Community Energy, } \\
\text { Inc. (8 of } 11 \text { coops offer program): } \\
\text { Adams Electric Co-op, Coles-Moultrie } \\
\text { Electric, Eastern Illini Electric, } \\
\text { McDonough Power, Menard, Rural } \\
\text { Electric Convenience Co-op, Shelby } \\
\text { Electric, Spoon River Electric Co-op }\end{array}$ & EcoEnergy & wind & 2005 & $3.0 \phi / \mathrm{kWh}$ \\
\hline IL & City of Naperville / Community Energy & $\begin{array}{l}\text { Renewable Energy } \\
\text { Option }\end{array}$ & $\begin{array}{l}\text { wind, small } \\
\text { hydro, PV }\end{array}$ & 2005 & $2.5 \phi / \mathrm{kWh}$ \\
\hline IL & $\begin{array}{l}\text { City of St. Charles/ComEd and } \\
\text { Community Energy, Inc. }\end{array}$ & $\underline{\text { TBD }}$ & wind, landfill gas & 2003 & Contribution \\
\hline IL & $\begin{array}{l}\text { Dairyland Power Cooperative: Jo-Carroll } \\
\text { Energy/Elizabeth }\end{array}$ & $\begin{array}{l}\text { Evergreen Renewable } \\
\text { Energy Program }\end{array}$ & $\begin{array}{l}\text { landfill gas, } \\
\text { biogas, hydro, } \\
\text { wind }\end{array}$ & 1997 & $1.5 \phi / \mathrm{kWh}$ \\
\hline IN & $\begin{array}{l}\text { Hoosier Energy ( } 5 \text { of } 17 \text { coops offer } \\
\text { program): Southeastern Indiana REMC, } \\
\text { South Central Indiana REMC, Utilities } \\
\text { District of Western Indiana REMC, } \\
\text { Decatur County REMC, Daviess-Martin } \\
\text { County REMC }\end{array}$ & EnviroWatts & landfill gas & 2001 & $\begin{array}{l}2.0 \phi / \mathrm{kWh}- \\
4.0 \phi / \mathrm{kWh}\end{array}$ \\
\hline IN & Indianapolis Power \& Light & Green Power Option & wind & 1998 & $0.35 \phi / \mathrm{kWh}$ \\
\hline IN & PSI Energy/Cinergy & Green Power Rider & $\begin{array}{l}\text { wind, PV, landfill } \\
\text { gas, digester } \\
\text { gas }\end{array}$ & 2001 & Contribution \\
\hline IN & $\begin{array}{l}\text { Wabash Valley Power Association (7 of } \\
27 \text { coops offer program): Boone REMC, } \\
\text { Hendricks Power Cooperative, Kankakee } \\
\text { Valley REMC, Miami-Cass REMC, } \\
\text { Tipmont REMC, White County REMC, } \\
\text { Northeastern REMC } \\
\end{array}$ & EnviroWatts & landfill gas & 2000 & $\begin{array}{l}0.9 \phi / \mathrm{kWh}- \\
1.0 \phi / \mathrm{kWh}\end{array}$ \\
\hline IA & Alliant Energy & $\underline{\text { Second Nature }}$ & landfill gas, wind & 2001 & $2.0 \phi / \mathrm{kWh}$ \\
\hline
\end{tabular}




\begin{tabular}{|c|c|c|c|c|c|}
\hline State & Utility Name & Program Name & Type & Start Date & Premium \\
\hline IA & $\begin{array}{l}\frac{\text { Associated Electric Cooperative, Inc.: }}{\text { Access Energy Cooperative, Chariton }} \\
\text { Valley Electric Cooperative, Southern } \\
\text { lowa Electric Cooperative }\end{array}$ & varies by utility & biomass, wind & 2003 & $\begin{array}{l}2.0 \phi / \mathrm{kWh}- \\
3.5 \phi / \mathrm{kWh}\end{array}$ \\
\hline IA & $\begin{array}{l}\text { Basin Electric Power Cooperative: Lyon } \\
\frac{\text { Rural, Harrison County, Nishnabotna }}{\text { Valley Cooperative, Northwest Rural }} \\
\text { Electric Cooperative, Western lowa }\end{array}$ & Prairie Winds & wind & 2000 & $0.5 \phi / \mathrm{kWh}$ \\
\hline IA & Cedar Falls Utilities & Harvest the Wind & wind & 2000 & $2.5 \phi / \mathrm{kWh}$ \\
\hline IA & $\begin{array}{l}\text { Central lowa Power Cooperatives (all } 12 \\
\text { coops/1 muni): Maquoketa Valley } \\
\text { Electric Cooperative, Eastern lowa REC, } \\
\text { East-Central lowa REC, Linn County } \\
\frac{\text { REC, Pella, TIP Rural Electric }}{\text { Cooperative, Clarke Electric }} \\
\frac{\text { Cooperative, Midland Power }}{\text { Cooperative, Guthrie County REC, }} \\
\text { Farmers Electric Cooperative, Southwest } \\
\text { lowa REC, Consumer Energy, South } \\
\text { lowa Municipal Electric Cooperative } \\
\text { Association }\end{array}$ & Wind Power & wind & 2006 & $\begin{array}{l}1.5 \phi / \mathrm{kWh}- \\
2.5 \phi / \mathrm{kWh}\end{array}$ \\
\hline IA & $\begin{array}{l}\text { Corn Belt Power Cooperatives (5 of } 11 \\
\text { coops offer program): Butler County } \\
\text { REC, Franklin REC, Grundy County } \\
\text { REC, Humboldt County REC, Sac } \\
\text { County REC }\end{array}$ & $\begin{array}{l}\text { Energy Wise } \\
\text { Renewables }\end{array}$ & wind & 2003 & $1.5 \phi / \mathrm{kWh}$ \\
\hline IA & $\begin{array}{l}\text { Dairyland Power Cooperative: } \\
\text { Allamakee-Clayton/Postville, Hawkeye } \\
\text { Tri-County/Cresco, Heartland } \\
\text { Power/Thompson \& St. Ansgar }\end{array}$ & $\begin{array}{l}\text { Evergreen Renewable } \\
\text { Energy Program }\end{array}$ & $\begin{array}{l}\text { hydro, wind, } \\
\text { landfill gas, } \\
\text { biogas }\end{array}$ & 1998 & $3.0 \phi / \mathrm{kWh}$ \\
\hline IA & Farmers Electric Cooperative & Green Power Project & biodiesel, wind & 2004 & Contribution \\
\hline IA & 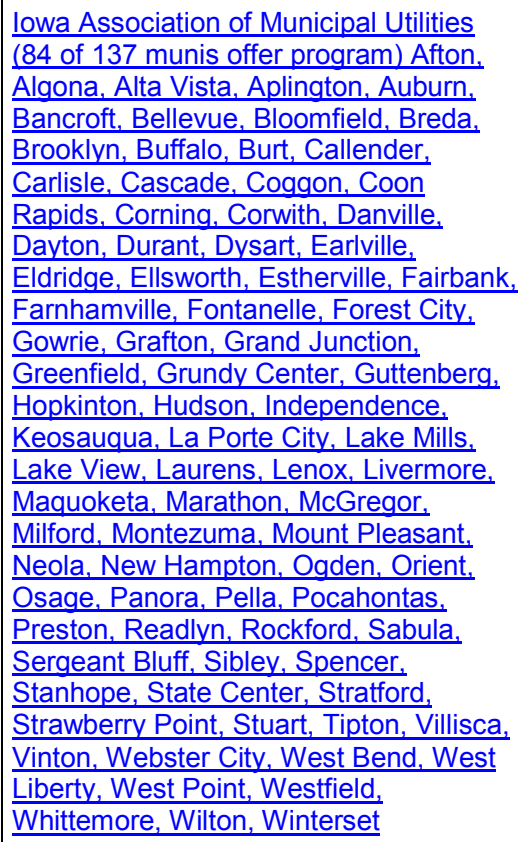 & Green City Energy & $\begin{array}{l}\text { wind, biomass, } \\
\mathrm{PV}\end{array}$ & 2003 & Varies by utility \\
\hline IA & MidAmerican Energy & Renewable Advantage & wind & 2004 & Contribution \\
\hline
\end{tabular}




\begin{tabular}{|c|c|c|c|c|c|}
\hline State & Utility Name & Program Name & Type & Start Date & Premium \\
\hline IA & $\begin{array}{l}\text { Missouri River Energy Services: Alton, } \\
\text { Atlantic, Denison, Fontanelle, Hartley, } \\
\text { Hawarden, Kimballton, Lake Park, } \\
\text { Manilla, Orange City, Paullina, Primghar, } \\
\text { Remsen, Rock Rapids, Sanborn, Shelby, } \\
\text { Sioux Center, Woodbine }\end{array}$ & RiverWinds & wind & 2003 & $\begin{array}{l}2.0 \phi / \mathrm{kWh}- \\
2.5 \phi / \mathrm{kWh}\end{array}$ \\
\hline IA & Muscatine Power and Water & Solar Muscatine & PV & 2004 & Contribution \\
\hline IA & Waverly Light \& Power & lowa Energy Tags & wind & 2001 & $2.0 \phi / \mathrm{kWh}$ \\
\hline IA & Waverly Light \& Power & Green Power Choice & wind & 2003 & Contribution \\
\hline KY & $\begin{array}{l}\text { East Kentucky Power Cooperative: Blue } \\
\text { Grass Energy, Clark, Cumberland, } \\
\text { Fleming-Mason, Grayson, Inter-County } \\
\text { Energy, Jackson, Licking Valley, Nolin, } \\
\text { Owen Electric, Salt River, Shelby, South } \\
\text { Kentucky }\end{array}$ & EnviroWatts & landfill gas & 2002 & $2.75 \phi / \mathrm{kWh}$ \\
\hline KY & $\begin{array}{l}\text { TVA: Bowling Green Municipal Utilities, } \\
\text { Franklin Electric Plant Board }\end{array}$ & Green Power Switch & $\begin{array}{l}\text { landfill gas, PV, } \\
\text { wind }\end{array}$ & 2000 & $2.67 \phi / \mathrm{kWh}$ \\
\hline MA & Concord Municipal Light Plant (CMLP) & Green Power & hydro & 2004 & $3.0 \phi / \mathrm{kWh}$ \\
\hline $\mathrm{Ml}$ & Lansing Board of Water and Light & $\begin{array}{l}\text { GreenWise Electric } \\
\text { Power }\end{array}$ & $\begin{array}{l}\text { landfill gas, } \\
\text { small hydro }\end{array}$ & 2001 & $3.0 \phi / \mathrm{kWh}$ \\
\hline MI & Traverse City Light and Power & Green Rate & wind & 1996 & $2.0 \phi / \mathrm{kWh}$ \\
\hline MI & Upper Peninsula Power Company & NatureWise & $\begin{array}{l}\text { wind, landfill gas } \\
\text { and animal } \\
\text { waste methane }\end{array}$ & 2004 & $4.0 \phi / \mathrm{kWh}$ \\
\hline $\mathrm{Ml}$ & We Energies & Energy for Tomorrow & $\begin{array}{l}\text { wind, landfill } \\
\text { gas, hydro }\end{array}$ & 2000 & $2.04 \phi / \mathrm{kWh}$ \\
\hline MN & Alliant Energy & Second Nature & landfill gas, wind & 2002 & $2.0 \phi / \mathrm{kWh}$ \\
\hline MN & $\begin{array}{l}\text { Austin Utilities, Owatonna Public Utilities, } \\
\text { Rochester Public Utilities }\end{array}$ & $\underline{\text { SolarChoice }}$ & $\begin{array}{l}\text { local PV } \\
\text { systems }\end{array}$ & 2006 & Contribution \\
\hline MN & $\begin{array}{l}\text { Basin Electric Power Cooperative: } \\
\text { Minnesota Valley Electric Coop, Sioux } \\
\text { Valley Southwestern }\end{array}$ & Prairie Winds & wind & 2002 & $0.5 \phi / \mathrm{kWh}$ \\
\hline MN & $\begin{array}{l}\text { Central Minnesota Municipal Power } \\
\text { Agency: Blue Earth, Delano, Glencoe, } \\
\text { Granite Falls, Janesville, Kenyon, Lake } \\
\text { Crystal, Madelia, Mt. Lake, New Ulm, } \\
\text { Sleepy Eye, Springfield, Truman, and } \\
\text { Windom }\end{array}$ & Green Energy Program & wind, landfill gas & 2000 & $\begin{array}{l}1.5 \phi / \mathrm{kWh}- \\
2.5 \phi / \mathrm{kWh}\end{array}$ \\
\hline MN & $\begin{array}{l}\text { Dairyland Power Cooperative: Freeborn- } \\
\text { Mower Cooperative / Albert Lea, } \\
\text { People's / Rochester, Tri-County / } \\
\text { Rushford }\end{array}$ & $\begin{array}{l}\text { Evergreen Renewable } \\
\text { Energy Program }\end{array}$ & $\begin{array}{l}\text { hydro, wind, } \\
\text { landfill gas, } \\
\text { biogas }\end{array}$ & 1998 & $1.5 \phi / \mathrm{kWh}$ \\
\hline
\end{tabular}




\begin{tabular}{|c|c|c|c|c|c|}
\hline State & Utility Name & Program Name & Type & Start Date & Premium \\
\hline MN & $\begin{array}{l}\text { Great River Energy (all } 28 \text { coops offer } \\
\text { program): Agralite, Arrowhead, BENCO } \\
\text { Electric, Brown County Rural Electric, } \\
\text { Connexus Energy, Co-op Light \& Power, } \\
\text { Crow Wing Power, Dakota Electric } \\
\text { Association, East Central Electric } \\
\text { Association, Federated Rural Electric, } \\
\text { Goodhue County, Itasca Mantrap } \\
\text { Cooperative, Kandiyohi Power } \\
\text { Cooperative, Lake Country Power, Lake } \\
\text { Region Electric Cooperative, McLeod } \\
\text { Cooperative Power, Meeker Cooperative } \\
\text { Light \& Power, Mille Lacs Electric } \\
\text { Cooperative, Minnesota Valley, Nobles } \\
\text { Cooperative Electric, North Itasca, } \\
\text { Redwood Electric Cooperative, } \\
\text { Runestone Electric, South Central } \\
\text { Electric Association, Stearns Electric, } \\
\text { Steele-Waseca, Todd-Wadena, Wright- } \\
\text { Hennepin Electric }\end{array}$ & $\begin{array}{l}\text { Wellspring Renewable } \\
\text { Wind Energy Program }\end{array}$ & wind & 1998 & $\begin{array}{c}1.55 \phi / \mathrm{kWh}- \\
2.0 \phi / \mathrm{kWh}\end{array}$ \\
\hline MN & Minnesota Power & WindSense & wind & 2002 & $2.5 \phi / \mathrm{kWh}$ \\
\hline MN & $\begin{array}{l}\frac{\text { Minnkota Power Cooperative: Beltrami, }}{\text { Clearwater Polk, North Star, PKM, Red }} \\
\text { Lake, Red River, Roseau, Wild Rice, } \\
\text { Thief River Falls }\end{array}$ & Infinity Wind Energy & wind & 1999 & $0.5 \phi / \mathrm{kWh}$ \\
\hline MN & $\begin{array}{l}\text { Missouri River Energy Services: Adrian, } \\
\text { Alexandria, Barnesville, Benson, } \\
\text { Breckenridge, Detroit Lakes, Elbow } \\
\text { Lake, Henning, Jackson, Lakefield, Lake } \\
\text { Park, Luverne, Madison, Moorhead, } \\
\text { Ortonville, St. James, Sauk Centre, } \\
\text { Staples, Wadena, Westbrook, } \\
\text { Worthington }\end{array}$ & RiverWinds & wind & 2002 & $\begin{array}{l}2.0 \phi / \mathrm{kWh}- \\
2.5 \phi / \mathrm{kWh}\end{array}$ \\
\hline $\mathrm{MN}$ & Moorhead Public Service & Capture the Wind & wind & 1998 & $1.5 \phi / \mathrm{kWh}$ \\
\hline MN & Otter Tail Power Company & TailWinds & wind & 2002 & $1.6 \phi / \mathrm{kWh}$ \\
\hline MN & $\begin{array}{l}\frac{\text { Southern Minnesota Municipal Power }}{\text { Agency (all 18 munis offer program): }} \\
\text { Fairmont Public Utilities, Wells Public } \\
\text { Utilities, Austin Utilities, Preston Public } \\
\text { Utilities, Spring Valley Utilities, Blooming } \\
\text { Prairie Public Utilities, Rochester Public } \\
\text { Utilities, Owatonna Public Utilities, } \\
\frac{\text { Waseca Utilities, St. Peter Municipal }}{\text { Utilities, Lake City Utilities, New Prague }} \\
\text { Utilities Commission, Redwood Falls } \\
\text { Public Utilities, Litchfield Public Utilities, } \\
\text { Princeton Public Utilities, North Branch } \\
\text { Water and Light, Mora Municipal Utilities, } \\
\text { Grand Marais Public Utilities }\end{array}$ & SMMPA Wind Power & wind & 2000 & $1.0 \phi / \mathrm{kWh}$ \\
\hline $\mathrm{MN}$ & Xcel Energy & WindSource & wind & 2003 & $2.0 \phi / \mathrm{kWh}$ \\
\hline MS & $\begin{array}{l}\text { TVA: City of Oxford, North East } \\
\text { Mississippi Electric Power Asssociation, } \\
\underline{\text { Starkville Electric System }}\end{array}$ & Green Power Switch & $\begin{array}{l}\text { landfill gas, PV, } \\
\text { wind }\end{array}$ & 2000 & $2.67 \phi / \mathrm{kWh}$ \\
\hline
\end{tabular}




\begin{tabular}{|c|c|c|c|c|c|}
\hline State & Utility Name & Program Name & Type & Start Date & Premium \\
\hline MO & $\begin{array}{l}\text { Associated Electric Cooperative, Inc.: } \\
\text { Black River Electric Cooperative, Boone } \\
\text { Electric Cooperative, Callaway Electric } \\
\text { Cooperative, Co-Mo Electric } \\
\text { Cooperative, Crawford Electric } \\
\text { Cooperative, Cuivre River Electric } \\
\text { Cooperative, Howell-Oregon Electric } \\
\text { Cooperative, Intercounty Electric } \\
\text { Cooperative, Laclede Electric } \\
\text { Cooperative, Lewis County Rural Electric } \\
\text { Cooperative, Macon Electric } \\
\text { Cooperative, White River Valley Electric } \\
\text { Cooperative }\end{array}$ & varies by utility & biomass, wind & 2003 & $\begin{array}{l}2.0 \phi / \mathrm{kWh}- \\
3.5 \phi / \mathrm{kWh}\end{array}$ \\
\hline MO & City Utilities of Springfield & WindCurrent & wind & 2000 & $5.0 \phi / \mathrm{kWh}$ \\
\hline MT & $\begin{array}{l}\text { Basin Electric Power Cooperative: Lower } \\
\text { Yellowstone }\end{array}$ & Prairie Winds & wind & 2000 & $0.5 \phi / \mathrm{kWh}$ \\
\hline MT & Northwestern Energy & E+ Green & wind, PV & 2003 & $2.0 \phi / \mathrm{kWh}$ \\
\hline MT & Park Electric Cooperative & Green Power Program & $\begin{array}{l}\text { various } \\
\text { renewables }\end{array}$ & 2002 & $1.02 \phi / \mathrm{kWh}$ \\
\hline MT & $\begin{array}{l}\text { Southern Montana Electric Generation } \\
\text { and Transmission Cooperative (5 coops } \\
\text { offer program): Fergus Electric, } \\
\text { Yellowstone Valley, Bear Tooth Electric, } \\
\text { Mid Yellowstone, and Tongue River } \\
\end{array}$ & $\begin{array}{l}\text { Environmentally } \\
\text { Preferred Power }\end{array}$ & wind, hydro & 2002 & $1.05 \phi / \mathrm{kWh}$ \\
\hline MT & $\begin{array}{l}\text { Tri-State Generation \& Transmission: Big } \\
\text { Horn Rural Electric Company }\end{array}$ & $\begin{array}{l}\text { Renewable Resource } \\
\text { Power Service }\end{array}$ & wind, hydro & 2001 & $1.25 \phi / \mathrm{kWh}$ \\
\hline MT & Vigilante Electric Cooperative & $\begin{array}{l}\text { Alternative Renewable } \\
\text { Energy Program }\end{array}$ & wind & 2003 & $1.1 \phi / \mathrm{kWh}$ \\
\hline NE & Lincoln Electric System & $\begin{array}{l}\text { LES Renewable } \\
\text { Energy Program }\end{array}$ & wind & 1998 & $4.3 \phi / \mathrm{kWh}$ \\
\hline NE & Omaha Public Power District & Green Power Program & landfill gas, wind & 2002 & $3.0 \phi / \mathrm{kWh}$ \\
\hline NE & $\begin{array}{l}\frac{\text { Tri-State Generation \& Transmission: }}{\text { Chimney Rock Public Power District, }} \\
\text { High West Energy, Inc., Highline Electric } \\
\text { Association, Midwest Electric } \\
\text { Cooperative Corporation, Niobrara } \\
\text { Electric Association, Inc., Northwest } \\
\text { Rural Public Power District, Panhandle } \\
\text { Rural Electric Membership, Roosevelt } \\
\text { Public Power District, Wheat Belt Public } \\
\text { Power District } \\
\end{array}$ & $\begin{array}{l}\text { Renewable Resource } \\
\text { Power Service }\end{array}$ & wind, hydro & 2001 & $1.25 \phi / \mathrm{kWh}$ \\
\hline NM & El Paso Electric & $\begin{array}{l}\text { Renewable Energy } \\
\underline{\text { Tariff }}\end{array}$ & wind & 2003 & $3.19 \phi / \mathrm{kWh}$ \\
\hline NM & $\begin{array}{l}\text { Los Alamos Department of Public } \\
\text { Utilities }\end{array}$ & Green Power & wind & 2005 & $1.8 \phi / \mathrm{kWh}$ \\
\hline NM & Public Service of New Mexico & PNM Sky Blue & wind & 2003 & $1.8 \phi / \mathrm{kWh}$ \\
\hline
\end{tabular}




\begin{tabular}{|c|c|c|c|c|c|}
\hline State & Utility Name & Program Name & Type & Start Date & Premium \\
\hline NM & $\begin{array}{l}\text { Tri-State Generation \& Transmission: } \\
\text { Central New Mexico Electric } \\
\text { Cooperative, Inc., Chimney Rock Public } \\
\text { Power District, Columbus Electric } \\
\text { Cooperative, Inc., Continental Divide } \\
\text { Electric Cooperative, Inc., Jemez } \\
\text { Mountains Electric Cooperative, Inc., Kit } \\
\text { Carson Electric Cooperative, Inc., Mora- } \\
\text { San Miguel Electric Cooperative, } \\
\text { Northern Rio Arriba Electric Cooperative, } \\
\text { Otero County Electric Cooperative, Inc.. } \\
\text { Sierra Electric Cooperative, Inc., Socorro } \\
\text { Electric Cooperative, Inc., Southwestern } \\
\text { Electric Cooperative, Inc., Springer } \\
\text { Electric Cooperative, Inc. }\end{array}$ & $\frac{\text { Renewable Resource }}{\text { Power Service }}$ & wind, hydro & 2001 & $1.25 \phi / \mathrm{kWh}$ \\
\hline NM & $\underline{X c e l ~ E n e r g y ~}$ & WindSource & wind & 1999 & $3.0 \phi / \mathrm{kWh}$ \\
\hline NC & Dominion North Carolina Power & NC GreenPower & $\begin{array}{l}\text { biomass, hydro, } \\
\text { landfill gas, PV, } \\
\text { wind }\end{array}$ & 2003 & $2.5 \phi-4.0 \phi / \mathrm{kWh}$ \\
\hline NC & Duke Energy & NC GreenPower & $\begin{array}{l}\text { biomass, hydro, } \\
\text { landfill gas, PV, } \\
\text { wind }\end{array}$ & 2003 & $2.5 \phi-4.0 \phi / \mathrm{kWh}$ \\
\hline NC & $\begin{array}{l}\text { ElectriCities: Town of Apex, Town of } \\
\text { Cornelius, Fayetteville PWC,Town of } \\
\text { Granite Falls, City of High Point, City of } \\
\text { Kinston, City of Laurinburg, City of } \\
\text { Lexington, City of Monroe, City of New } \\
\text { Bern, City of Newton, City of Shelby, City } \\
\text { of Statesville, City of Washington }\end{array}$ & NC GreenPower & $\begin{array}{l}\text { biomass, hydro, } \\
\text { landfill gas, PV, } \\
\text { wind }\end{array}$ & 2003 & $2.5 \phi-4.0 \phi / \mathrm{kWh}$ \\
\hline NC & $\begin{array}{l}\text { NC Electric Cooperatives (19 of } 27 \\
\text { coops offer program): Albemarle EMC, } \\
\text { Blue Ridge Electric Membership Corp., } \\
\text { Brunswick Electric Membership Corp., } \\
\text { Carteret Craven Electric Coop., Central } \\
\text { Electric Membership Corporation, } \\
\text { Edgecombe-Martin County Electric } \\
\text { Membership Corp., EnergyUnited, Four } \\
\text { County Electric Membership Corp., } \\
\text { Haywood Electric Membership Corp., } \\
\text { Jones-Onslow Electric Membership } \\
\text { Corp., Lumbee River Electric } \\
\text { Membership Corporation, Pee Dee } \\
\text { Electric Membership Corp., Piedmont } \\
\text { Electric Membership Corp., Randolph } \\
\text { Electric Membership Corp., Roanoke } \\
\text { Electric Membership Corp., Rutherford } \\
\text { Electric Membership Corporation, Tri- } \\
\text { County Electric Membership Corp., } \\
\text { Union Power Cooperative, Wake Electric } \\
\text { Membership Corp. }\end{array}$ & NC GreenPower & $\begin{array}{l}\text { biomass, hydro, } \\
\text { landfill gas, PV, } \\
\text { wind }\end{array}$ & 2003 & $2.5 \phi-4.0 \phi / \mathrm{kWh}$ \\
\hline NC & Progress Energy / CP\&L & NC GreenPower & $\begin{array}{l}\text { biomass, hydro, } \\
\text { landfill gas, PV, } \\
\text { wind }\end{array}$ & 2003 & $2.5 \phi-4.0 \phi / \mathrm{kWh}$ \\
\hline NC & TVA: Mountain Electric Cooperative & Green Power Switch & $\begin{array}{l}\text { landfill gas, PV, } \\
\text { wind }\end{array}$ & 2000 & $2.67 \phi / \mathrm{kWh}$ \\
\hline ND & $\begin{array}{l}\text { Basin Electric Power Cooperative: Oliver } \\
\text { Mercer Electric Coop, Mor-gran-sou } \\
\text { Electric Coop, KEM Electric Coop, North } \\
\text { Central Electric Coop, Verendrye, } \\
\text { Capital , Northern Plains, Dakota Valley, } \\
\text { Burke Divide, Montrail Williams, } \\
\text { McKenzie Electric Coop, West Plains, } \\
\end{array}$ & PrairieWinds & wind & 2000 & $0.5 \phi / \mathrm{kWh}$ \\
\hline
\end{tabular}




\begin{tabular}{|c|c|c|c|c|c|}
\hline State & Utility Name & Program Name & Type & Start Date & Premium \\
\hline & Slope Electric Coop & & & & \\
\hline ND & $\begin{array}{l}\text { Minnkota Power Cooperative: Cass } \\
\text { County Electric, Cavalier Rural Electric, } \\
\text { Northern Municipal Power Agency (12 } \\
\text { municipals) }\end{array}$ & Infinity Wind Energy & wind & 1999 & $0.5 \phi / \mathrm{kWh}$ \\
\hline ND & $\begin{array}{l}\text { Missouri River Energy Services: City of } \\
\text { Lakota }\end{array}$ & RiverWinds & wind & 2002 & $\begin{array}{l}2.0 \phi / \mathrm{kWh}- \\
2.5 \phi / \mathrm{kWh}\end{array}$ \\
\hline $\mathrm{OH}$ & $\begin{array}{l}\text { American Municipal Power-Ohio / Green } \\
\text { Mountain Energy: City of Bowling Green, } \\
\underline{\text { Cuyahoga Falls, Wyandotte }}\end{array}$ & Nature's Energy & $\begin{array}{l}\text { small hydro, } \\
\text { landfill gas, wind }\end{array}$ & 2003 & $\begin{array}{l}1.3 \phi / \mathrm{kWh}- \\
1.5 \phi / \mathrm{kWh}\end{array}$ \\
\hline $\mathrm{OH}$ & Buckeye Power & EnviroWatts & landfill gas & 2006 & $2.0 \phi / \mathrm{kWh}$ \\
\hline OK & $\begin{array}{l}\text { Associated Electric Cooperative, Inc.: } \\
\text { Central Rural Electric Cooperative }\end{array}$ & varies by utility & biomass, wind & 2003 & $\begin{array}{l}2.0 \phi / \mathrm{kWh}- \\
3.5 \phi / \mathrm{kWh}\end{array}$ \\
\hline OK & OG\&E Electric Services & OG\&E Wind Power & wind & 2003 & $-0.246 \phi / \mathrm{kWh}$ \\
\hline OK & $\begin{array}{l}\text { Oklahoma Municipal Power Authority: } \\
\text { Tonkawa, Altus, Frederick, Okeene, } \\
\text { Praque Municipal Utilities and Edmond } \\
\text { Electric }\end{array}$ & Pure \& Simple & wind & 2004 & $\begin{array}{c}1.8 \phi / k W h \\
(-0.45 \phi / k W h \\
\text { Edmond })\end{array}$ \\
\hline OK & $\begin{array}{l}\frac{\text { Western Farmers Electric Cooperative }}{\text { (19 of } 19 \text { coops offer program): Alfalfa }} \\
\text { Electric Cooperative, Caddo Electric } \\
\text { Cooperative, Canadian Valley Electric } \\
\text { Cooperative, Choctaw Electri } \\
\text { Cooperative, Cimmaron Electric } \\
\text { Cooperative, Cotton Electric } \\
\text { Cooperative, East Central Oklahoma } \\
\text { Electric Cooperative, Harmon Electric } \\
\text { Cooperative, Kay Electric Cooperative, } \\
\text { Kiamichi Electric Cooperative, Kiwash } \\
\text { Electric Cooperative, Northfork Electric } \\
\text { Cooperative, Northwestern Electric } \\
\text { Cooperative, Oklahoma Electric } \\
\text { Cooperative, People's Electric } \\
\text { Cooperative, Red River Valley Rural } \\
\text { Electric Cooperative, Rural Electric } \\
\text { Cooperative, Southeastern Electric } \\
\text { Cooperative, Southwest Rural Electric } \\
\text { Cooperative }\end{array}$ & WindWorks & wind & 2004 & $0.5 \phi / \mathrm{kWh}$ \\
\hline OR & $\frac{\text { City of Ashland/Bonneville }}{\text { Environmental Foundation }}$ & Renewable Pioneers & $P V$, wind & 2003 & $2.0 \phi / \mathrm{kWh}$ \\
\hline OR & Columbia River PUD & Choice Energy & wind & 2005 & $1.5 \phi / \mathrm{kWh}$ \\
\hline OR & $\begin{array}{l}\text { Emerald People's Utility District/Green } \\
\text { Mountain Energy }\end{array}$ & $\begin{array}{l}\text { Choose Renewable } \\
\text { Electricity }\end{array}$ & $\begin{array}{l}\text { wind, } \\
\text { geothermal }\end{array}$ & 2003 & $1.2 \phi / \mathrm{kWh}$ \\
\hline OR & Eugene Water \& Electric Board & EWEB Wind Power & wind & 1999 & $0.91 \phi / k W h$ \\
\hline OR & Idaho Power & Green Power Program & various & 2001 & $0.98 \phi / \mathrm{kWh}$ \\
\hline OR & Midstate Electric Cooperative & $\begin{array}{l}\text { Environmentally- } \\
\text { Preferred Power }\end{array}$ & wind & 1999 & $2.5 \phi / \mathrm{kWh}$ \\
\hline OR & Oregon Trail Electric Cooperative & Green Power & wind & 2002 & $1.5 \phi / \mathrm{kWh}$ \\
\hline OR & PacifiCorp: Pacific Power & $\frac{\text { Blue Sky QS }}{\text { (Commercial Only) }}$ & wind & 2004 & $\begin{array}{c}\text { Sliding scale } \\
\text { depending on } \\
\text { size }\end{array}$ \\
\hline
\end{tabular}




\begin{tabular}{|c|c|c|c|c|c|}
\hline State & Utility Name & Program Name & Type & Start Date & Premium \\
\hline OR & PacifiCorp: Pacific Power & Blue Sky Block & wind & 2000 & $1.95 \phi / \mathrm{kWh}$ \\
\hline OR & $\begin{array}{l}\text { PacifiCorp: Pacific Power / } 3 \text { Phases } \\
\text { Energy Services }\end{array}$ & Blue Sky Usage & $\begin{array}{l}\text { wind, biomass, } \\
\text { PV }\end{array}$ & 2002 & $0.78 \phi / \mathrm{kWh}$ \\
\hline OR & $\begin{array}{l}\text { PacifiCorp: Pacific Power / } 3 \text { Phases } \\
\text { Energy Services }\end{array}$ & Blue Sky Habitat & $\begin{array}{l}\text { wind, biomass, } \\
\text { PV }\end{array}$ & 2002 & $\begin{array}{c}0.78 \phi / \mathrm{kWh}+ \\
\$ 2.50 / \mathrm{mo} \text {. } \\
\text { donation }\end{array}$ \\
\hline OR & $\begin{array}{l}\text { Pacific Northwest Generating } \\
\text { Cooperative: Central Electric } \\
\text { Cooperative, Clearwater Power, } \\
\text { Consumers Power, Douglas Electric } \\
\text { Cooperative, Umatilla Electric } \\
\text { Cooperative } 5 \text { of } 16 \text { coops offer } \\
\text { program) }\end{array}$ & Green Power & landfill gas & 1998 & $\begin{array}{l}1.8 \phi / \mathrm{kWh}- \\
2.0 \phi / \mathrm{kWh}\end{array}$ \\
\hline OR & $\begin{array}{l}\text { Portland General Electric / Green } \\
\text { Mountain Energy }\end{array}$ & Green Source & $\begin{array}{l}\text { existing } \\
\text { geothermal, } \\
\text { hydro, new wind }\end{array}$ & 2002 & $0.8 \phi / \mathrm{kWh}$ \\
\hline OR & $\begin{array}{l}\text { Portland General Electric / Green } \\
\text { Mountain Energy }\end{array}$ & Healthy Habitat & $\begin{array}{l}\text { existing } \\
\text { geothermal, } \\
\text { hydro, new wind }\end{array}$ & 2002 & $\begin{array}{l}0.8 \phi / \mathrm{kWh}+ \\
\$ 2.50 / \mathrm{mo} . \\
\text { donation }\end{array}$ \\
\hline OR & Portland General Electric Company & $\begin{array}{l}\frac{\text { Clean Wind for Medium }}{\text { to Large Commercial \& }} \\
\underline{\text { Industrial Accounts }}\end{array}$ & wind & 2003 & $1.7 \phi / \mathrm{kWh}$ \\
\hline OR & Portland General Electric Company & Clean Wind Power & wind & 2002 & $1.75 \phi / \mathrm{kWh}$ \\
\hline SC & $\begin{array}{l}\frac{\text { Santee Cooper: Aiken Electric }}{\text { Cooperative, Berkeley Electric }} \\
\text { Cooperative, Blue Ridge Electric, } \\
\text { Coastal Electric Cooperative, Edisto } \\
\text { Electric Cooperative, Fairfield Electric } \\
\text { Cooperative, Horry Electric Cooperative, } \\
\text { Laurens Electric Cooperative, Lynches } \\
\text { River Electric Cooperative, Marlboro } \\
\text { Electric Cooperative, Mid-Carolina } \\
\text { Electric Cooperative, Palmetto Electric } \\
\text { Cooperative, Pee Dee Electric } \\
\text { Cooperative, Santee Electric } \\
\text { Cooperative, Tri-County Electric } \\
\text { Cooperative, York Electric Cooperative } \\
\end{array}$ & Green Power Program & landfill gas & 2001 & $3.0 \phi / \mathrm{kWh}$ \\
\hline SD & $\begin{array}{l}\text { Basin Electric Power Cooperative: Bon } \\
\text { Homme-Yankton Electric Assn., Central } \\
\text { Electric Cooperative Association, } \\
\text { Charles Mix Electric Association, City of } \\
\text { Elk Point, Clay-Union Electric } \\
\text { Corporation, Codington-Clark Electric } \\
\text { Cooperative, Dakota Energy } \\
\text { Cooperative, Douglas Electric } \\
\text { Cooperative, FEM Electric Association, } \\
\text { H-D Electric Cooperative, Kingsbury } \\
\text { Electric Cooperative, Lyon-Lincoln } \\
\text { Electric Cooperative, McCook Electric } \\
\text { Cooperative, Northern Electric } \\
\text { Cooperative, Oahe Electric Cooperative, } \\
\text { Renville-Sibley Coop. Power Assn., } \\
\text { Sioux Valley Southwestern Electric } \\
\text { Coop, Southeastern Electric Coop, } \\
\text { Union County Electric Cooperative, } \\
\text { Whetstone Valley Electric Cooperative, } \\
\text { Black Hills Electric Coop, LaCreek } \\
\text { Electric Coop, West River Power } \\
\text { Association, Butte Electric Coop, Cherry } \\
\text { Todd Electric Coop, Moreau Grand } \\
\text { Grand Electric Cooperative, Rosebud } \\
\end{array}$ & Prairie Winds & wind & 2000 & $0.5 \phi / \mathrm{kWh}$ \\
\hline
\end{tabular}




\begin{tabular}{|c|c|c|c|c|c|}
\hline State & Utility Name & Program Name & Type & Start Date & Premium \\
\hline SD & $\begin{array}{l}\text { Missouri River Energy Services: City of } \\
\text { Vermillion }\end{array}$ & RiverWinds & wind & 2002 & $\begin{array}{l}2.0 \phi / \mathrm{kWh}- \\
2.5 \phi / \mathrm{kWh}\end{array}$ \\
\hline SD & $\begin{array}{l}\text { Tri-State Generation \& Transmission: } \\
\text { Niobrara Electric Association, Inc. }\end{array}$ & $\begin{array}{l}\text { Renewable Resource } \\
\text { Power Service }\end{array}$ & wind, hydro & 2001 & $1.25 \phi / \mathrm{kWh}$ \\
\hline TN & 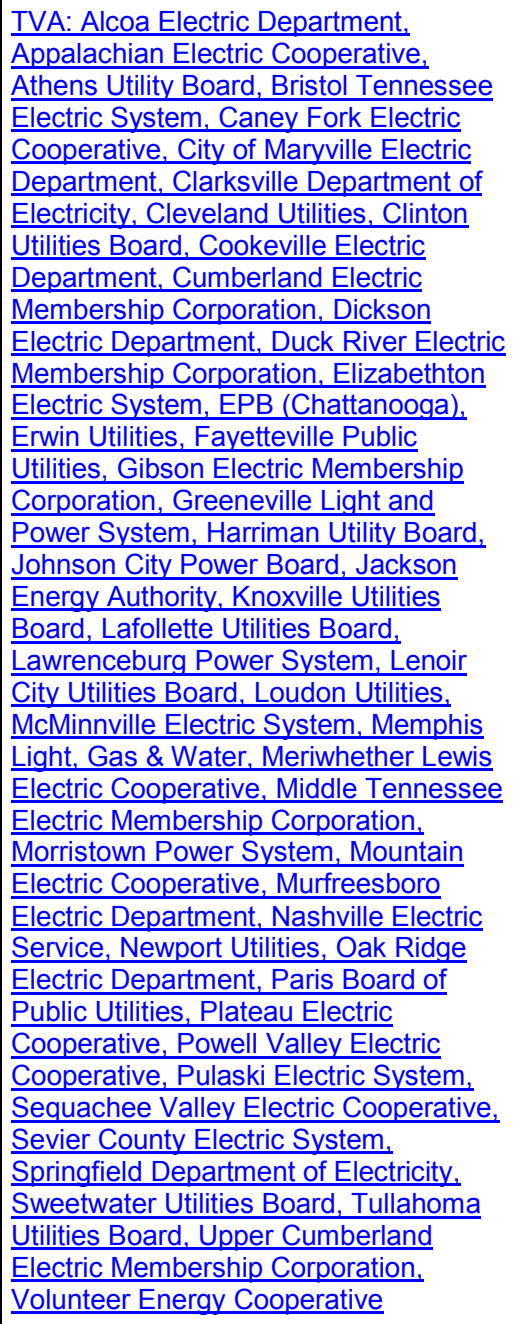 & Green Power Switch & $\begin{array}{l}\text { landfill gas, } P V \text {, } \\
\text { wind }\end{array}$ & 2000 & $2.67 \phi / \mathrm{kWh}$ \\
\hline TX & Austin Energy (City of Austin) & GreenChoice & wind, landfill gas & $2000 / 1997$ & $-0.134 \phi / \mathrm{kWh}$ \\
\hline TX & City Public Service of San Antonio & Windtricity & wind & 2000 & $3.0 \phi / \mathrm{kWh}$ \\
\hline $\mathrm{TX}$ & El Paso Electric Company & $\begin{array}{l}\text { Renewable Energy } \\
\text { Tariff }\end{array}$ & wind & 2001 & $1.92 \phi / \mathrm{kWh}$ \\
\hline UT & City of St. George & Clean Green Power & $\begin{array}{l}\text { wind, small } \\
\text { hydro }\end{array}$ & 2005 & $2.95 \phi / \mathrm{kWh}$ \\
\hline UT & Deseret Power & GreenWay & various & 2004 & $1.95 \phi / \mathrm{kWh}$ \\
\hline UT & Pacificorp: Utah Power & Blue Sky & wind & 2000 & $1.95 \phi / \mathrm{kWh}$ \\
\hline UT & $\begin{array}{l}\text { Tri-State Generation \& Transmission: } \\
\text { Empire Electric Association, Inc. }\end{array}$ & $\begin{array}{l}\text { Renewable Resource } \\
\text { Power Service }\end{array}$ & wind, hydro & 2001 & $1.25 \phi / \mathrm{kWh}$ \\
\hline VT & Central Vermont Public Service & CVPS Cow Power & biogas & 2004 & $4.0 \phi / \mathrm{kWh}$ \\
\hline VT & Green Mountain Power & $\begin{array}{l}\text { CoolHome I } \\
\text { CoolBusiness }\end{array}$ & wind, biomass & 2002 & Contribution \\
\hline
\end{tabular}




\begin{tabular}{|c|c|c|c|c|c|}
\hline State & Utility Name & Program Name & Type & Start Date & Premium \\
\hline VT & Green Mountain Power & $\begin{array}{l}\text { Greener Mountain } \\
\text { Power }\end{array}$ & $\begin{array}{l}\text { various } \\
\text { renewables }\end{array}$ & 2006 & $4.097 \phi / \mathrm{kkWh}$ \\
\hline WA & Avista Utilities & Buck-A-Block & wind & 2002 & $0.33 \phi / \mathrm{kWh}$ \\
\hline WA & Benton County Public Utility District & Green Power Program & $\begin{array}{l}\text { landfill gas, } \\
\text { wind, hydro }\end{array}$ & 1999 & Contribution \\
\hline WA & Chelan County PUD & $\begin{array}{l}\text { Sustainable Natural } \\
\text { Alternative Power } \\
\underline{\text { SNAP) }}\end{array}$ & $\begin{array}{l}\text { PV, wind, micro } \\
\text { hydro }\end{array}$ & 2001 & Contribution \\
\hline WA & Clallam County PUD & $\begin{array}{l}\text { Clallam County PUD } \\
\text { Green Power Program }\end{array}$ & landfill gas & 2001 & $0.69 \phi / \mathrm{kWh}$ \\
\hline WA & Clark Public Utilities & Green Lights & $P V$, wind & 2002 & $1.5 \phi / \mathrm{kWh}$ \\
\hline WA & Cowlitz PUD & $\begin{array}{l}\text { Renewable Resource } \\
\text { Energy }\end{array}$ & wind, PV & 2002 & $2.0 \phi / \mathrm{kWh}$ \\
\hline WA & Grant County PUD & $\begin{array}{l}\text { Alternative Energy } \\
\text { Resources Program }\end{array}$ & wind & 2002 & $2.0 \phi / \mathrm{kWh}$ \\
\hline WA & Grays Harbor PUD & Green Power & wind & 2002 & $3.0 \phi / \mathrm{kWh}$ \\
\hline WA & Lewis County PUD & $\begin{array}{l}\text { Green Power Energy } \\
\text { Rate }\end{array}$ & wind & 2003 & $2.0 \phi / \mathrm{kWh}$ \\
\hline WA & Mason County PUD No. 3 & $\begin{array}{l}\text { Mason Evergreen } \\
\text { Power }\end{array}$ & wind & 2003 & $1.0 \phi / \mathrm{kWh}$ \\
\hline WA & Orcas Power \& Light & Go Green & wind, hydro & 1999 & $3.5 \phi / \mathrm{kWh}$ \\
\hline WA & Pacific County PUD & Green Power & landfill gas & 2002 & $1.05 \phi / \mathrm{kWh}$ \\
\hline WA & Pacificorp: Pacific Power & Blue Sky & wind & 2000 & $1.95 \phi / \mathrm{kWh}$ \\
\hline WA & Peninsula Light & Green by Choice & $\begin{array}{l}\text { wind, hydro, } \\
\text { biogas }\end{array}$ & 2002 & $2.0 \phi / \mathrm{kWh}$ \\
\hline WA & Puget Sound Energy & Green Power Plan & $\begin{array}{l}\text { wind, } P V, \\
\text { biogas }\end{array}$ & 2002 & $2.0 \phi / \mathrm{kWh}$ \\
\hline WA & Seattle City Light & Seattle Green Power & PV, biogas & 2002 & Contribution \\
\hline WA & Seattle City Light & Green Up & wind & 2005 & $1.5 \phi / \mathrm{kWh}$ \\
\hline WA & Snohomish County Public Utility District & Planet Power & wind & 2002 & $2.0 \phi / \mathrm{kWh}$ \\
\hline WA & Tacoma Power & EverGreen Options & wind & 2000 & $1.2 \phi / \mathrm{kWh}$ \\
\hline WI & Alliant Energy & Second Nature & wind, landfill gas & 2000 & $2.0 \phi / \mathrm{kWh}$ \\
\hline WI & $\begin{array}{l}\text { Dairyland Power Cooperative: Barron } \\
\text { Electric, Bayfield/ Iron River, Chippewa / } \\
\text { Cornell Valley, Clark / Greenwood, Dunn } \\
\text { I Menomonie, Eau Claire / Fall Creek, } \\
\text { Jackson / Black River Falls, Jump River / } \\
\text { Ladysmith, Oakdale, Pierce-Pepin / } \\
\text { Ellsworth, Polk-Burnett / Centuria, Price / } \\
\text { Phillips, Richland, Riverland / Arcadia, } \\
\text { St. Croix / Baldwin, Scenic Rivers / } \\
\text { Lancaster, Taylor / Medford, Vernon / } \\
\text { Westby }\end{array}$ & $\begin{array}{l}\text { Evergreen Renewable } \\
\text { Energy Program }\end{array}$ & $\begin{array}{l}\text { hydro, wind, } \\
\text { landfill gas, } \\
\text { biogas }\end{array}$ & 1998 & $1.5 \phi / \mathrm{kWh}$ \\
\hline WI & Great River Energy: Head of the Lakes & $\begin{array}{l}\text { Wellspring Renewable } \\
\text { Wind Energy Program }\end{array}$ & wind & 1997 & $\begin{array}{l}1.45 \phi / \mathrm{kWh}- \\
2.0 \phi / \mathrm{kWh}\end{array}$ \\
\hline WI & Madison Gas \& Electric & Wind Power Program & wind & 1999 & $3.3 \phi / \mathrm{kWh}$ \\
\hline WI & We Energies & Energy for Tomorrow & $\begin{array}{l}\text { landfill gas, PV, } \\
\text { hydro, wind }\end{array}$ & 1996 & $1.37 \phi / \mathrm{kWh}$ \\
\hline
\end{tabular}




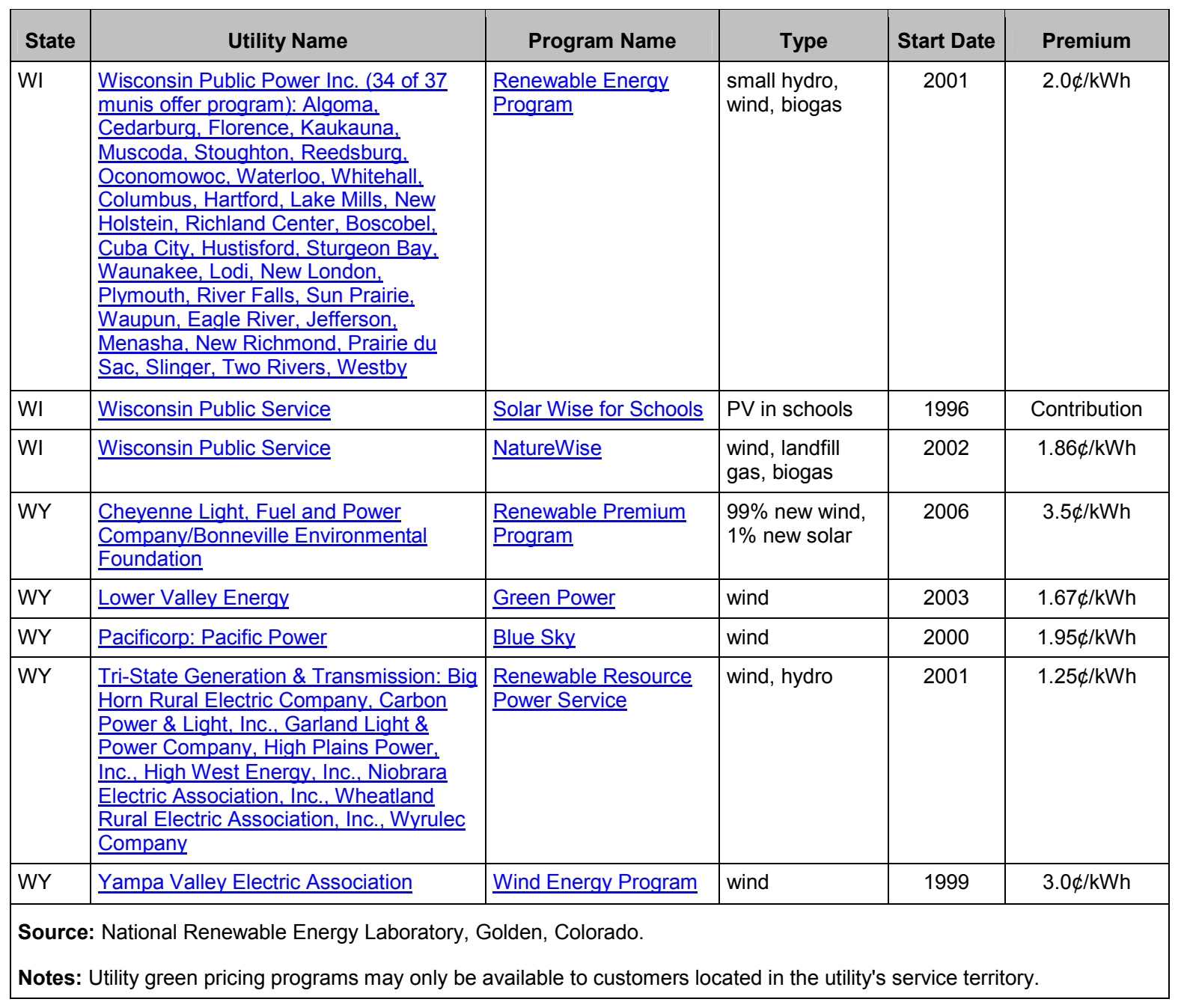




\section{Appendix F}

Table F-1: Utilities That Have Lowered Their Base Green Power Premium

\begin{tabular}{|c|c|c|c|c|}
\hline Utility & $\begin{array}{l}\text { Year of } \\
\text { Change }\end{array}$ & $\begin{array}{l}\text { Initial } \\
\text { Premium } \\
\phi / \mathrm{kWh} \\
\end{array}$ & $\begin{array}{c}\text { Revised } \\
\text { Premium } \\
\phi / \mathrm{kWh} \\
\end{array}$ & Reason Stated \\
\hline $\begin{array}{l}\text { Loveland Water and } \\
\text { Power }\end{array}$ & 2006 & 2.50 & 1.50 & Switched to regional RECs product. \\
\hline $\begin{array}{l}\text { Madison Gas and } \\
\text { Electric }\end{array}$ & 2006 & 3.33 & 2.68 & Higher cost of natural gas generation. \\
\hline $\begin{array}{l}\text { Mason County PUD } \\
\# 3\end{array}$ & 2006 & 2.00 & 1.00 & $\begin{array}{l}\text { Lower wind energy and transmissions } \\
\text { costs. }\end{array}$ \\
\hline $\begin{array}{l}\text { Minnkota Power } \\
\text { Cooperative }\end{array}$ & 2006 & 1.50 & 0.50 & $\begin{array}{l}\text { Higher costs of conventional } \\
\text { generation sources. }\end{array}$ \\
\hline Otter Tail Power & 2006 & 2.60 & 1.60 & $\begin{array}{l}\text { Lower-cost source of wind energy; an } \\
\text { increase in the embedded generation } \\
\text { cost to which the renewable energy } \\
\text { cost is compared; and reduced } \\
\text { marketing and promotion costs for the } \\
\text { program. }\end{array}$ \\
\hline We Energies & 2006 & 2.04 & 1.37 & Higher fossil fuel prices. \\
\hline $\begin{array}{l}\text { Wisconsin Public } \\
\text { Service }\end{array}$ & 2006 & 1.86 & 1.00 & $\begin{array}{l}\text { Lower renewable energy purchase } \\
\text { costs and administrative costs. }\end{array}$ \\
\hline $\begin{array}{l}\text { Basin Electric Power } \\
\text { Cooperative }\end{array}$ & 2005 & 2.50 & 0.50 & $\begin{array}{l}\text { Greatly expanded wind energy supply } \\
\text { lowered costs; switched to "green tag" } \\
\text { product. }\end{array}$ \\
\hline Lower Valley Energy & 2005 & 1.67 & 1.17 & Eliminated administrative margin. \\
\hline $\begin{array}{l}\text { Wisconsin Public } \\
\text { Service }\end{array}$ & 2005 & 2.65 & 1.86 & $\begin{array}{l}\text { Lower renewable energy purchase } \\
\text { costs and administrative costs. }\end{array}$ \\
\hline Avista Utilities & 2004 & 1.80 & 0.33 & $\begin{array}{l}\text { Lower renewable energy purchase } \\
\text { costs. }\end{array}$ \\
\hline Fort Collins Utilities & 2004 & 2.50 & 1.00 & $\begin{array}{l}\text { RECs purchase from new wind energy } \\
\text { project. }\end{array}$ \\
\hline $\begin{array}{l}\text { Portland General } \\
\text { Electric }\end{array}$ & 2004 & 3.50 & 1.75 & Lower cost of wind power. \\
\hline TECO & 2004 & 10.00 & 5.00 & $\begin{array}{l}\text { Greater use of lower-cost renewable } \\
\text { resources. }\end{array}$ \\
\hline PacifiCorp & 2003 & 2.95 & 1.95 & $\begin{array}{l}\text { Lower renewable energy costs and } \\
\text { greater customer participation. }\end{array}$ \\
\hline $\begin{array}{l}\text { Basin Electric Power } \\
\text { Cooperative }\end{array}$ & 2002 & 3.00 & 2.50 & $\begin{array}{l}\text { Wind power development costs less } \\
\text { than originally estimated. }\end{array}$ \\
\hline PacifiCorp & 2001 & 4.95 & 2.95 & $\begin{array}{l}\text { Reductions in the forecast cost for new } \\
\text { wind energy and increases in the } \\
\text { forecast for market alternatives. }\end{array}$ \\
\hline
\end{tabular}




\section{Appendix G}

\section{Table G-1: Retail Green Power Product Offerings in Competitive Electricity Markets, November 2006}

\begin{tabular}{|c|c|c|c|c|c|}
\hline State & Company & Product Name & $\begin{array}{l}\text { Residential } \\
\text { Price } \\
\text { Premium }\end{array}$ & Resource Mix ${ }^{2}$ & Certification \\
\hline CT & $\begin{array}{l}\text { CL\&P/United Illuminating } \\
\text { Sterling Planet (CT Clean } \\
\text { Energy Options Program) }\end{array}$ & $\begin{array}{l}\text { Sterling Select } 50 \% \\
\text { or } 100 \% \text { of usage }\end{array}$ & $1.15 \phi / \mathrm{kWh}$ & $\begin{array}{l}33 \% \text { new wind, } \\
33 \% \text { small hydro, } \\
34 \% \text { landfill gas }\end{array}$ & - \\
\hline DC & PEPCO Energy Services (3) & $\begin{array}{l}\text { Green Electricity } \\
10 \%, 51 \% \text { or } 100 \% \\
\text { of usage }\end{array}$ & $\begin{array}{l}3.38 \phi / \mathrm{kWh} \\
\text { (for } 100 \% \\
\text { usage) }\end{array}$ & landfill gas & - \\
\hline DC & PEPCO Energy Services (3) & $\begin{array}{l}\text { NewWind Energy } \\
51 \% \text { or } 100 \% \text { of } \\
\underline{\text { usage }}\end{array}$ & $\begin{array}{l}4.08 \phi \mathrm{kWh} \\
\text { (for } 100 \% \\
\text { usage) }\end{array}$ & new wind & - \\
\hline DC & $\begin{array}{l}\text { Washington Gas Energy } \\
\underline{\text { Services / Community Energy }}\end{array}$ & $\begin{array}{l}1 \text { year fixed price } \\
\text { electricity with } 5 \% \\
\text { wind }\end{array}$ & $2.3 \phi / \mathrm{kWh}$ & $5 \%$ new wind & - \\
\hline ME & $\begin{array}{l}\text { Maine Renewable } \\
\text { Energy/Maine Interfaith Power } \\
\underline{\text { \& Light (4) }}\end{array}$ & Maine Clean Power & $2.62 \phi / \mathrm{kWh}$ & $\begin{array}{l}100 \% \text { low impact } \\
\text { hydro }\end{array}$ & - \\
\hline ME & $\begin{array}{l}\text { Maine Renewable } \\
\text { Energy/Maine Interfaith Power } \\
\underline{\text { \& Light (4) }}\end{array}$ & $\begin{array}{l}\text { Maine Clean Power } \\
\underline{\text { Plus }}\end{array}$ & $3.12 \phi / \mathrm{kWh}$ & $\begin{array}{l}80 \% \text { low impact } \\
\text { hydro, } 20 \% \text { wind }\end{array}$ & - \\
\hline MD & PEPCO Energy Services (5) & $\begin{array}{l}\frac{\text { Green Electricity }}{10 \%, 51 \% \text { or } 100 \%} \\
\underline{\text { of usage }}\end{array}$ & $\begin{array}{l}1.3 \phi / \mathrm{kWh} \\
\text { (for } 100 \% \\
\text { RE) }\end{array}$ & landfill gas & - \\
\hline MD & PEPCO Energy Services (5) & $\begin{array}{l}\text { Wind Electricity } 51 \% \\
\text { or } 100 \% \text { of usage }\end{array}$ & $\begin{array}{l}2.53 \phi / \mathrm{kWh} \\
\text { (for } 100 \% \\
\text { wind) }\end{array}$ & new wind & - \\
\hline MD & $\begin{array}{l}\text { Washington Gas Energy } \\
\text { Services/ Community Energy }\end{array}$ & $\begin{array}{l}\frac{1 \text { Year Price }}{\text { Protection with } 5 \%} \\
\underline{\text { wind }}\end{array}$ & $0.12 \phi / \mathrm{kWh}$ & $5 \%$ wind & - \\
\hline MA & Cape Light Compact (6) & $\begin{array}{l}\text { Cape Light Compact } \\
\text { Green } 50 \% \text { or } 100 \% \\
\end{array}$ & $\begin{array}{c}2.5 \phi / \mathrm{kWh} \\
\text { (for } 100 \% \\
\text { usage) }\end{array}$ & $\begin{array}{l}75 \% \text { small hydro, } \\
24 \% \text { new wind or } \\
\text { landfill gas, } 1 \% \\
\text { new solar }\end{array}$ & - \\
\hline MA & $\begin{array}{l}\text { Massachusetts } \\
\text { Electric/Nantucket Electric/ } \\
\text { Clear Sky Power } \\
\end{array}$ & Clear Sky Home & $7.2 \phi / \mathrm{kWh}$ & $100 \%$ biomass & - \\
\hline MA & $\begin{array}{l}\text { Massachusetts } \\
\text { Electric/Nantucket } \\
\text { Electric/Community Energy }\end{array}$ & $\begin{array}{l}\frac{\text { New Wind Energy }}{\text { and Water } 50 \% \text { or }} \\
\frac{100 \% \text { of usage }}{\underline{100}}\end{array}$ & $\begin{array}{l}2.0 \phi / \mathrm{kWh} \\
\text { (for } 100 \% \\
\text { usage) }\end{array}$ & $\begin{array}{l}70 \% \text { small hydro, } \\
30 \% \text { new wind }\end{array}$ & Green-e \\
\hline MA & $\begin{array}{l}\text { Massachusetts } \\
\text { Electric/Nantucket } \\
\text { Electric/Mass Energy } \\
\underline{\text { Consumers Alliance }}\end{array}$ & $\begin{array}{l}\frac{\text { New England }}{\text { GreenStart } 50 \% \text { or }} \\
\underline{100 \% \text { of usage }}\end{array}$ & $\begin{array}{c}2.4 \phi / \mathrm{kWh} \\
\text { (for } 100 \% \\
\text { usage) }\end{array}$ & $\begin{array}{l}75 \% \text { small hydro, } \\
25 \% \text { new } \\
\text { biomass, wind, } \\
\text { and solar }\end{array}$ & - \\
\hline MA & $\begin{array}{l}\text { Massachusetts } \\
\text { Electric/Nantucket } \\
\text { Electric/Sterling Planet }\end{array}$ & MA Clean Choice & $5.0 \phi / \mathrm{kWh}$ & $\begin{array}{l}33 \% \text { new wind, } \\
33 \% \text { new landfill } \\
\text { gas; } 33 \% \text { small } \\
\text { hydro }\end{array}$ & $\begin{array}{c}\text { Environmental } \\
\text { Resources } \\
\text { Trust }\end{array}$ \\
\hline
\end{tabular}




\begin{tabular}{|c|c|c|c|c|c|}
\hline State & Company & Product Name & $\begin{array}{l}\text { Residential } \\
\text { Price } \\
\text { Premium }\end{array}$ & Resource Mix & Certification \\
\hline MI & Consumers Energy & $\underline{\text { Green Generation }}$ & $1.67 \phi / \mathrm{kWh}$ & $\begin{array}{l}68 \% \text { new wind, } \\
32 \% \text { landfill gas }\end{array}$ & Green-e \\
\hline NJ & $\begin{array}{l}\text { PSE\&G/JCP\&L/Atlantic City } \\
\text { Electric/Rockland } \\
\text { Electric/Community Energy }\end{array}$ & $\begin{array}{l}\frac{\text { NJ Clean Power }}{\text { Choice }- \text { Community }} \\
\text { Energy }\end{array}$ & $1.3 \phi / \mathrm{kWh}$ & $\begin{array}{l}50 \% \text { wind, } 49 \% \\
\text { low impact hydro, } \\
1 \% \text { solar }\end{array}$ & - \\
\hline NJ & $\begin{array}{l}\text { PSE\&G/JCP\&L/Atlantic City } \\
\text { Electric/Rockland } \\
\text { Electric/Green Mountain } \\
\text { Energy }\end{array}$ & $\begin{array}{l}\text { NJ Clean Power } \\
\text { Choice - Green } \\
\text { Mountain Energy }\end{array}$ & $1.3 \phi / \mathrm{kWh}$ & $\begin{array}{l}50 \% \text { wind, } 50 \% \\
\text { small hydro }\end{array}$ & - \\
\hline NJ & $\begin{array}{l}\text { PSE\&G/JCP\&L/Atlantic City } \\
\text { Electric/Rockland } \\
\text { Electric/Jersey-Atlantic Wind }\end{array}$ & $\begin{array}{l}\frac{\text { NJ Clean Power }}{\text { Choice }- \text { Wind and }} \\
\underline{\text { Water }}\end{array}$ & $2.9 \phi / \mathrm{kWh}$ & $\begin{array}{l}50 \% \text { wind, } 50 \% \\
\text { low impact hydro }\end{array}$ & - \\
\hline NJ & $\begin{array}{l}\text { PSE\&G/JCP\&L/Atlantic City } \\
\text { Electric/Rockland } \\
\text { Electric/Jersey-Atlantic Wind }\end{array}$ & $\frac{\text { NJ Clean Power }}{\underline{\text { Choice - Wind }}}$ & $5.5 \phi / \mathrm{kWh}$ & $\begin{array}{l}\text { 100-kWh blocks of } \\
\text { new wind }\end{array}$ & - \\
\hline NJ & $\begin{array}{l}\text { PSE\&G/JCP\&L/Atlantic City } \\
\text { Electric/Rockland } \\
\text { Electric/Sterling Planet }\end{array}$ & $\begin{array}{l}\frac{\text { NJ Clean Power }}{\text { Choice }- \text { Sterling }} \\
\underline{\text { Select }}\end{array}$ & $1.2 \phi / \mathrm{kWh}$ & $\begin{array}{l}33 \% \text { wind, } 33 \% \\
\text { small hydro, } 34 \% \\
\text { landfill gas }\end{array}$ & $\begin{array}{l}\text { Environmental } \\
\text { Resources } \\
\text { Trust }\end{array}$ \\
\hline NY & $\underline{\text { ConEdison Solutions (7) }}$ & $\underline{\text { Green Power }}$ & $1.0 \phi / \mathrm{kWh}$ & $\begin{array}{l}35 \% \text { new wind, } \\
65 \% \text { small hydro }\end{array}$ & Green-e \\
\hline NY & $\underline{\text { Con Edison /Sterling Planet }}$ & NY Clean Choice & $2.5 \phi / \mathrm{kWh}$ & $\begin{array}{l}40 \% \text { new wind, } \\
30 \% \text { small hydro, } \\
30 \% \text { bioenergy }\end{array}$ & $\begin{array}{c}\text { Environmental } \\
\text { Resources } \\
\text { Trust }\end{array}$ \\
\hline NY & ECONnergy & $\underline{\text { Keep It Clean }}$ & $3 \phi / \mathrm{kWh}$ & $100 \%$ wind & - \\
\hline NY & $\begin{array}{l}\text { Energy Cooperative of New } \\
\underline{\text { York }(8)}\end{array}$ & $\frac{\text { Renewable }}{\text { Electricity }}$ & $0.75 \phi / \mathrm{kWh}$ & $\begin{array}{l}25 \% \text { new wind, } \\
75 \% \text { landfill gas }\end{array}$ & - \\
\hline NY & $\begin{array}{l}\text { Long Island Power Authority I } \\
\text { Community Energy }\end{array}$ & New Wind Energy & $2.5 \phi / \mathrm{kWh}$ & new wind & - \\
\hline NY & $\begin{array}{l}\text { Long Island Power Authority / } \\
\text { Community Energy }\end{array}$ & $\begin{array}{l}\text { New Wind } \\
\text { Energy/Small Hydro }\end{array}$ & $1.3 \phi / \mathrm{kWh}$ & $\begin{array}{l}60 \% \text { new wind, } \\
40 \% \text { small hydro }\end{array}$ & - \\
\hline NY & $\begin{array}{l}\text { Long Island Power Authority I } \\
\text { Sterling Planet }\end{array}$ & New York Clean & $1.0 \phi / \mathrm{kWh}$ & $\begin{array}{l}55 \% \text { small hydro, } \\
35 \% \text { biomass, } \\
10 \% \text { new wind }\end{array}$ & $\begin{array}{c}\text { Environmental } \\
\text { Resources } \\
\text { Trust }\end{array}$ \\
\hline NY & $\begin{array}{l}\text { Long Island Power Authority / } \\
\underline{\text { Sterling Planet }}\end{array}$ & Sterling Green & $1.5 \phi / \mathrm{kWh}$ & $\begin{array}{l}40 \% \text { new wind, } \\
30 \% \text { small hydro, } \\
30 \% \text { bioenergy }\end{array}$ & $\begin{array}{c}\text { Environmental } \\
\text { Resources } \\
\text { Trust }\end{array}$ \\
\hline NY & NYSEG/Community Energy & $\begin{array}{l}\text { Catch the Wind/New } \\
\text { Wind Energy }\end{array}$ & $2.5 \phi / \mathrm{kWh}$ & new wind & - \\
\hline NY & $\begin{array}{l}\text { Niagara Mohawk / Community } \\
\text { Energy }\end{array}$ & $\begin{array}{l}\frac{60 \% \text { New Wind }}{\text { Energy and } 40 \%} \\
\underline{\text { Small Hydro }}\end{array}$ & $1.3 \phi / \mathrm{kWh}$ & $\begin{array}{l}60 \% \text { new wind, } \\
40 \% \text { hydro }\end{array}$ & - \\
\hline NY & $\begin{array}{l}\text { Niagara Mohawk / Community } \\
\text { Energy }\end{array}$ & $\underline{\text { NewWind Energy }}$ & $2.5 \phi / \mathrm{kWh}$ & $100 \%$ new wind & - \\
\hline NY & Niagara Mohawk / EnviroGen & Think Green! & $1.0 \phi / \mathrm{kWh}$ & $\begin{array}{l}75 \% \text { landfill gas, } \\
25 \% \text { low impact } \\
\text { hydro }\end{array}$ & - \\
\hline
\end{tabular}




\begin{tabular}{|c|c|c|c|c|c|}
\hline State & Company & Product Name & $\begin{array}{l}\text { Residential } \\
\text { Price } \\
\text { Premium }\end{array}$ & Resource Mix & Certification \\
\hline NY & $\begin{array}{l}\text { Niagara Mohawk/ Sterling } \\
\text { Planet }\end{array}$ & $\underline{\text { Sterling Green }}$ & $1.5 \phi / \mathrm{kWh}$ & $\begin{array}{l}50 \% \text { wind, } 50 \% \\
\text { small hydro }\end{array}$ & $\begin{array}{c}\text { Environmental } \\
\text { Resources } \\
\text { Trust }\end{array}$ \\
\hline NY & $\frac{\text { Niagara Mohawk/Green }}{\text { Mountain Energy }}$ & $\begin{array}{l}\text { Green Mountain } \\
\text { Energy Electricity }\end{array}$ & $1.5 \phi / \mathrm{kWh}$ & $\begin{array}{l}50 \% \text { small hydro, } \\
50 \% \text { wind }\end{array}$ & Green-e \\
\hline NY & $\begin{array}{l}\text { Rochester Gas \& } \\
\text { Electric/Community Energy }\end{array}$ & $\begin{array}{l}\text { Catch the } \\
\text { Wind/NewWind } \\
\text { Energy }\end{array}$ & $2.5 \phi / \mathrm{kWh}$ & $\begin{array}{l}\text { 100-kWh blocks of } \\
\text { new wind }\end{array}$ & - \\
\hline NY & $\begin{array}{l}\text { Suburban Energy Services } \\
\text { ISterling Planet }\end{array}$ & $\begin{array}{l}\frac{\text { Sterling Green }}{\text { Renewable }} \\
\underline{\text { Electricity }}\end{array}$ & $1.5 \phi / \mathrm{kWh}$ & $\begin{array}{l}40 \% \text { new wind, } \\
30 \% \text { small hydro, } \\
30 \% \text { bioenergy }\end{array}$ & $\begin{array}{c}\text { Environmental } \\
\text { Resources } \\
\text { Trust }\end{array}$ \\
\hline PA & $\begin{array}{l}\text { Energy Cooperative of } \\
\text { Pennsylvania (9) }\end{array}$ & EcoChoice 100 & $10.5 \phi / \mathrm{kWh}$ & $\begin{array}{l}89 \% \text { landfill gas, } \\
10 \% \text { hydro, } 35 \% \\
\text { biomass }\end{array}$ & Green-e \\
\hline PA & $\begin{array}{l}\text { PECO Energy/Community } \\
\text { Energy (9) }\end{array}$ & PECO Wind & $2.54 \phi / \mathrm{kWh}$ & $\begin{array}{l}100-\mathrm{kWh} \text { of new } \\
\text { wind }\end{array}$ & - \\
\hline PA & PEPCO Energy Services (9) & $\begin{array}{l}\text { Green Electricity } \\
10 \%, 51 \% \text { or } 100 \% \\
\text { of usage }\end{array}$ & $\begin{array}{c}5.2 \phi / \mathrm{kWh} \\
\text { (for } 100 \% \\
\text { usage) }\end{array}$ & landfill gas & - \\
\hline PA & PEPCO Energy Services (9) & $\begin{array}{l}\text { Wind } 51 \% \text { or } 100 \% \\
\text { of usage }\end{array}$ & $\begin{array}{c}5.9 \phi / \mathrm{kWh} \\
\text { (for } 100 \% \\
\text { usage) }\end{array}$ & new wind & - \\
\hline RI & $\begin{array}{l}\text { Narragansett Electric/ Clear } \\
\underline{\text { Sky Power }}\end{array}$ & Clear Sky Home & $7.2 \phi / \mathrm{kWh}$ & $\begin{array}{l}100 \% \text { new } \\
\text { bioenergy }\end{array}$ & - \\
\hline RI & $\begin{array}{l}\text { Narragansett Electric / } \\
\text { Community Energy, Inc. }\end{array}$ & $\begin{array}{l}40 \% \text { NewWind } / 60 \% \\
\underline{\text { Small Hydro }}\end{array}$ & $1.5 \phi / \mathrm{kWh}$ & $\begin{array}{l}60 \% \text { small hydro, } \\
40 \% \text { new wind }\end{array}$ & - \\
\hline RI & $\frac{\text { Narragansett Electric / }}{\text { Community Energy, Inc. }}$ & $\begin{array}{l}50 \% \text { NewWind } / 50 \% \\
\text { Small Hydro }\end{array}$ & $2.0 \phi / \mathrm{kWh}$ & $\begin{array}{l}50 \% \text { small hydro, } \\
50 \% \text { new wind }\end{array}$ & - \\
\hline RI & $\begin{array}{l}\text { Narragansett Electric / } \\
\text { People's Power \& Light }\end{array}$ & $\begin{array}{l}\text { New England } \\
\text { GreenStart RI } 50 \% \\
\text { or } 100 \% \text { of usage }\end{array}$ & $1.5 \phi / \mathrm{kWh}$ & $\begin{array}{l}70 \% \text { small hydro, } \\
17 \% \text { biomass, } \\
13 \% \text { wind and } \\
\text { solar }\end{array}$ & - \\
\hline RI & $\begin{array}{l}\text { Narragansett Electric / Sterling } \\
\text { Planet }\end{array}$ & $\begin{array}{l}\text { Sterling Supreme } \\
\underline{100 \%}\end{array}$ & $1.98 \phi / \mathrm{kWh}$ & $\begin{array}{l}40 \% \text { small hydro, } \\
25 \% \text { biomass, } \\
25 \% \text { new solar, } \\
10 \% \text { wind }\end{array}$ & $\begin{array}{c}\text { Environmental } \\
\text { Resources } \\
\text { Trust }\end{array}$ \\
\hline TX & First Choice Power & $\begin{array}{l}\text { Simply Better } \\
\text { Renewable }\end{array}$ & $-0.7 \phi / \mathrm{kWh}$ & $100 \%$ renewables & \\
\hline TX & Gexa Energy (10) & Gexa Green & $-0.2 \phi / \mathrm{kWh}$ & $100 \%$ renewable & - \\
\hline TX & $\begin{array}{l}\text { Green Mountain Energy } \\
\underline{\text { Company }(10)}\end{array}$ & Pollution Free & $-0.26 \phi / k W h$ & Wind and hydro & - \\
\hline TX & $\begin{array}{l}\text { Green Mountain Energy } \\
\underline{\text { Company }(10)}\end{array}$ & $\begin{array}{l}\text { Pollution Free: } \\
\text { Reliable Rate }\end{array}$ & $-0.55 \phi / k W h$ & wind and hydro & - \\
\hline$T X$ & Reliant Energy (10) & Renewable Plan & $1.0 \phi / \mathrm{kWh}$ & $100 \%$ wind & - \\
\hline$T X$ & TXU Energy & $\frac{\text { TXU Energy } 100 \%}{\text { EarthWise }}$ & $1.0 \phi / \mathrm{kWh}$ & $100 \%$ wind & - \\
\hline
\end{tabular}




\begin{tabular}{|c|c|c|c|c|c|}
\hline State & Company & Product Name & $\begin{array}{l}\text { Residential } \\
\text { Price } \\
\text { Premium }\end{array}$ & Resource Mix ${ }^{2}$ & Certification \\
\hline TX & TXU Energy & $\frac{\text { TXU Energy }}{\text { EarthWise } 18}$ & $-0.02 \phi / k W h$ & $10 \%$ wind & - \\
\hline VA & PEPCO Energy Services (11) & $\begin{array}{l}\frac{\text { Green Electricity }}{10 \%, 51 \% \text { or } 100 \%} \\
\underline{\text { of usage }}\end{array}$ & $\begin{array}{c}3.6 \phi / \mathrm{kWh} \\
\text { (for } 100 \% \\
\text { usage) }\end{array}$ & landfill gas & - \\
\hline VA & PEPCO Energy Services (11) & $\frac{\frac{\text { NewWind Energy }}{51 \% \text { or } 100 \% \text { of }}}{\text { usage }}$ & $\begin{array}{c}4.3 \phi / \mathrm{kWh} \\
\text { (for } 100 \% \\
\text { wind) }\end{array}$ & new wind & - \\
\hline
\end{tabular}

${ }^{1}$ Prices updated as of November 2006 and may also apply to small commercial customers. Prices may differ for large commercial/industrial customers and may vary by service territory.

${ }^{2}$ New is defined as operating or repowered after January 1, 1997 based on the Green-e standard.

${ }^{3}$ Offered in PEPCO service territory. Product prices are for new customers based on annual average costs for customers in PEPCO's service territory (8.0 ф/kWh), 11/1/06. http://www.dcpsc.org/hottopics/Electric Rate Comparisons 2.shtm

${ }^{4}$ Price premium is for Central Maine Power service territory based on standard offer of $8.38 \phi / \mathrm{kWh}$. http://www.state.me.us/mpuc/industries/electricity/standard offer/current sorates $\mathrm{cmp}$.html

${ }^{5}$ Product offered in Baltimore Gas and Electric and PEPCO service territories. Price is for PEPCO service territory based on price to compare of $10.08 \phi / \mathrm{kWh}$. http://www.pepco.com/home/choice/md/compare/

${ }^{6}$ Price premium is based on a comparison to the NSTAR standard offer of $10.45 \phi / \mathrm{kWh}$. http://www.capelightcompact.org/doc.ccml?10,801,675510,cap675510,,Doc, page.html

${ }_{7}^{7}$ Price premium is based on a comparison to ConEdison Solutions' standard electricity product in the ConEdison service territory.

${ }^{8}$ Offered in Niagara Mohawk and NYSEG service territories.

${ }^{9}$ Product prices are for PECO service territory (price to compare of $6.7 \phi / \mathrm{kWh}$ ).

http://www.oca.state.pa.us/Industry/Electric/elecomp/pecor.pdf.

${ }_{10}$ Product prices reflect difference in average price for $1000 \mathrm{kWh}$ based on price to beat of $15.0 \phi / \mathrm{kWh}$ for TXU service territory (specifically Dallas, Texas). Prices derived from http://www.powertochoose.org/.

${ }_{11}$ Products are available in Dominion Virginia Power service territory (price to compare of $6.078 \phi / \mathrm{kWh}$ ) http://www.yesvachoice.com/howtochoose/pricetocompare.pdf 


\section{Appendix H}

Table H-1: Renewable Energy Certificate Retail Products, November 2006

\begin{tabular}{|c|c|c|c|c|c|}
\hline $\begin{array}{l}\text { Certificate } \\
\text { Marketer }\end{array}$ & Product Name & $\begin{array}{l}\text { Renewable } \\
\text { Resources }\end{array}$ & $\begin{array}{l}\text { Location of } \\
\text { Renewable } \\
\text { Resources }\end{array}$ & $\begin{array}{l}\text { Residential Price } \\
\text { Premiums* }\end{array}$ & Certification \\
\hline $\begin{array}{l}3 \text { Phases Energy } \\
\underline{\text { Services }}\end{array}$ & Green Certificates & $100 \%$ new wind & Nationwide & $2.0 \phi / \mathrm{kWh}$ & Green-e \\
\hline $\begin{array}{l}\text { Bonneville } \\
\text { Environmental } \\
\text { Foundation }\end{array}$ & $\begin{array}{l}\text { Brighter Future } \\
\underline{\text { Green Tags }}\end{array}$ & $\begin{array}{l}90 \% \text { new wind, } \\
10 \% \text { new solar }\end{array}$ & West & $2.4 \phi / \mathrm{kWh}$ & Green-e \\
\hline $\begin{array}{l}\text { Bonneville } \\
\text { Environmental } \\
\text { Foundation } \\
\end{array}$ & $\begin{array}{l}\text { Cooler Future } \\
\underline{\text { Green Tags }}\end{array}$ & $\begin{array}{l}99 \% \text { new wind, } \\
1 \% \text { new solar }\end{array}$ & Nationwide & $2.0 \phi / \mathrm{kWh}$ & Green-e \\
\hline Carbonfund.org & MyGreenFuture & $\begin{array}{l}99 \% \text { new wind, } \\
1 \% \text { new solar }\end{array}$ & Nationwide & $0.5 \phi / \mathrm{kWh}$ & Green-e \\
\hline Carbonfund.org & $\underline{\text { Carbon Offsets }}$ & $\begin{array}{l}\text { wind, solar, } \\
\text { biomass, } \\
\text { efficiency, } \\
\text { reforestation }\end{array}$ & Nationwide & $\begin{array}{l}\text { \$5.50/ton CO2 } \\
\text { (donation) }\end{array}$ & $\begin{array}{c}\text { Environmental } \\
\text { Resource } \\
\text { Trust }^{* *}\end{array}$ \\
\hline $\begin{array}{l}\text { Clean Energy } \\
\text { Partnership/Sterling } \\
\text { Planet }\end{array}$ & $\begin{array}{l}\text { National New Clean } \\
\text { Energy Mix }\end{array}$ & $\begin{array}{l}24 \% \text { wind, } 25 \% \\
\text { biomass, } 50 \% \\
\text { landfill gas, } 1 \% \\
\text { solar }\end{array}$ & Nationwide & $\begin{array}{l}0.5 \phi / \mathrm{kWh}- \\
0.75 \phi / \mathrm{kWh}\end{array}$ & $\begin{array}{c}\text { Environmental } \\
\text { Resources } \\
\text { Trust }\end{array}$ \\
\hline $\begin{array}{l}\text { Clean Energy } \\
\text { Partnership/Sterling } \\
\text { Planet }\end{array}$ & National New Wind & $100 \%$ new wind & Nationwide & $0.96 \phi / \mathrm{kWh}$ & - \\
\hline$\underline{\text { Clean and Green }}$ & $\begin{array}{l}\text { Clean and Green } \\
\underline{\text { Membership }}\end{array}$ & $100 \%$ new wind & Nationwide & $3.0 \phi / \mathrm{kWh}$ & Green-e \\
\hline Community Energy & New Wind Energy & $100 \%$ new wind & $\begin{array}{l}\text { Colorado, } \\
\text { Illinois, New } \\
\text { York, } \\
\text { Pennsylvania, } \\
\text { West Virginia }\end{array}$ & $\begin{array}{l}2.0 \phi / \mathrm{kWh}- \\
2.5 \phi / \mathrm{kWh}\end{array}$ & Green-e \\
\hline $\begin{array}{l}\text { Conservation } \\
\underline{\text { Services Group }}\end{array}$ & ClimateSAVE & $\begin{array}{l}95 \% \text { new } \\
\text { wind/hydro, } 5 \% \\
\text { new solar }\end{array}$ & $\begin{array}{l}\text { Kansas, New } \\
\text { England } \\
\text { (wind/hydro), } \\
\text { New York } \\
\text { (solar) }\end{array}$ & $\begin{array}{l}1.65 \phi / \mathrm{kWh}- \\
1.75 \phi / \mathrm{kWh}\end{array}$ & Green-e \\
\hline $\begin{array}{l}\text { Green Mountain } \\
\text { Energy }\end{array}$ & $\begin{array}{l}\text { Green Mountain } \\
\text { Energy } \\
\text { (Pennsylvania) }\end{array}$ & $100 \%$ wind & Nationwide & $1.99 \phi / \mathrm{kWh}$ & - \\
\hline
\end{tabular}




\begin{tabular}{|c|c|c|c|c|c|}
\hline $\begin{array}{l}\text { Certificate } \\
\text { Marketer }\end{array}$ & Product Name & $\begin{array}{l}\text { Renewable } \\
\text { Resources }\end{array}$ & $\begin{array}{l}\text { Location of } \\
\text { Renewable } \\
\text { Resources }\end{array}$ & $\begin{array}{l}\text { Residential Price } \\
\text { Premiums* }\end{array}$ & Certification \\
\hline $\begin{array}{l}\text { Maine Interfaith } \\
\text { Power \& Light/BEF }\end{array}$ & $\begin{array}{l}\text { Green Tags } \\
\text { (supplied by BEF) }\end{array}$ & $\begin{array}{l}99 \% \text { new wind, } \\
1 \% \text { new solar }\end{array}$ & Nationwide & $2.0 \phi / \mathrm{kWh}$ & - \\
\hline $\begin{array}{l}\text { Mass Energy } \\
\text { Consumers } \\
\text { Alliance }\end{array}$ & $\begin{array}{l}\text { New England Wind } \\
\underline{\text { Fund }}\end{array}$ & $100 \%$ new wind & New England & $\begin{array}{l}\sim 5.0 \phi / \mathrm{kWh} \\
\text { (donation) }\end{array}$ & - \\
\hline NativeEnergy & $\underline{\text { CoolDriver }}$ & $\begin{array}{l}\text { New wind and } \\
\text { biogas }\end{array}$ & Nationwide & $\begin{array}{l}1.2 \phi / \mathrm{kWh}, \$ 12 \\
\text { per ton CO2 } \\
\text { avoided }\end{array}$ & $* * *$ \\
\hline NativeEnergy & CoolWatts & $100 \%$ new wind & Nationwide & $0.8 \phi / \mathrm{kWh}$ & Green-e \\
\hline NativeEnergy & $\underline{\text { WindBuilders }}$ & $100 \%$ new wind & $\begin{array}{l}\text { South } \\
\text { Dakota, North } \\
\text { Dakota }\end{array}$ & $\begin{array}{l}\sim 1.2 \phi / \mathrm{kWh}, \\
\$ 12 \text { per ton of } \\
\text { CO2 avoided }\end{array}$ & $* * *$ \\
\hline NativeEnergy & Remooable Energy & $100 \%$ new biogas & Pennsylvania & $\begin{array}{l}0.8 \phi / \mathrm{kWh}- \\
1.0 \phi / \mathrm{kWh}\end{array}$ & $* * *$ \\
\hline $\begin{array}{l}\text { Renewable Choice } \\
\text { Energy }\end{array}$ & American Wind & $100 \%$ new wind & Nationwide & $2.5 \phi / \mathrm{kWh}$ & Green-e \\
\hline$\frac{\text { Renewable }}{\text { Ventures }}$ & $\begin{array}{l}\text { PVUSA Solar Green } \\
\underline{\text { Certificates }}\end{array}$ & $100 \%$ solar & California & $3.3 \phi / \mathrm{kWh}$ & Green-e \\
\hline SKY energy, Inc. & $\begin{array}{l}\text { Wind-e Renewable } \\
\text { Energy }\end{array}$ & $100 \%$ new wind & Nationwide & $2.4 \phi / \mathrm{kWh}$ & Green-e \\
\hline Sterling Planet & $\begin{array}{l}\text { Sterling Green } \\
\underline{\text { Energy }}\end{array}$ & $\begin{array}{l}100 \% \text { new wind, } \\
\text { hydro, } \\
\text { geothermal, } \\
\text { methane, or } \\
\text { bioenergy }\end{array}$ & Nationwide & $1.5 \phi / \mathrm{kWh}$ & - \\
\hline Sterling Planet & Sterling Solar & $100 \%$ new solar & Nationwide & $7.5 \phi / \mathrm{kWh}$ & - \\
\hline TerraPass Inc. & TerraPass & $\begin{array}{l}\text { Various (including } \\
\text { efficiency and } \\
\text { CO2 offsets) }\end{array}$ & Nationwide & $\sim \$ 10 /$ ton CO2 & - \\
\hline $\begin{array}{l}\text { Waverly Light \& } \\
\text { Power }\end{array}$ & lowa Energy Tags & $100 \%$ wind & lowa & $2.0 \phi / \mathrm{kWh}$ & - \\
\hline WindCurrent & $\frac{\text { Chesapeake }}{\underline{\text { Windcurrent }}}$ & $100 \%$ new wind & $\begin{array}{l}\text { Mid-Atlantic } \\
\text { States }\end{array}$ & $2.5 \phi / \mathrm{kWh}$ & Green-e \\
\hline $\begin{array}{l}\text { Footnote: } \\
\text { * Product prices are } \\
\text { typically able to neg } \\
\text { ** Product is source } \\
\text { *** The Climate Neu } \\
\text { NA = Not applicable }\end{array}$ & $\begin{array}{l}\text { pdated as of July } 2006 \\
\text { late price premiums. } \\
\text { from Green-e and ERT } \\
\text { al Network certifies the }\end{array}$ & $\begin{array}{l}\text { Premium may also a } \\
\text { certified RECs. ERT } \\
\text { nethodology used to }\end{array}$ & $\begin{array}{l}\text { ply to small con } \\
\text { Iso certifies the } \\
\text { alculate the CO }\end{array}$ & $\begin{array}{l}\text { nercial customers. L } \\
\text { ntire product portfoli } \\
\text { emissions offset. }\end{array}$ & ge users are \\
\hline
\end{tabular}




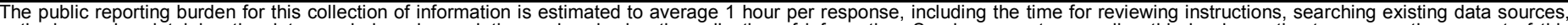

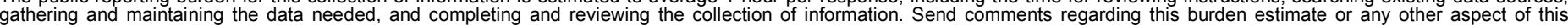

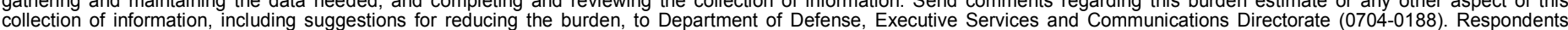

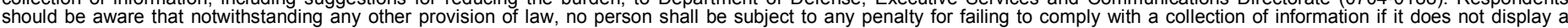

should be aware that notwithstandin

PLEASE DO NOT RETURN YOUR FORM TO THE ABOVE ORGANIZATION.

\begin{tabular}{l|l|l|l} 
1. REPORT DATE $(D D-M M-Y Y Y Y)$ & 2. REPORT TYPE & 3. DATES COVERED (FrOm - TO)
\end{tabular}

November 2006

Technical Report

4. TITLE AND SUBTITLE
Green Power Marketing in the United States: A Status Report

(Ninth Edition)

5a. CONTRACT NUMBER

DE-AC36-99-G010337

5b. GRANT NUMBER

5c. PROGRAM ELEMENT NUMBER

5d. PROJECT NUMBER

NREL/TP-640-40904

Lori Bird and Blair Swezey 5e. TASK NUMBER

ASG6.1003

5f. WORK UNIT NUMBER
7. PERFORMING ORGANIZATION NAME(S) AND ADDRESS(ES)

National Renewable Energy Laboratory

1617 Cole Blvd.

Golden, CO 80401-3393
8. PERFORMING ORGANIZATION

REPORT NUMBER

NREL/TP-620-40904

9. SPONSORING/MONITORING AGENCY NAME(S) AND ADDRESS(ES)

10. SPONSOR/MONITOR'S ACRONYM(S) NREL

11. SPONSORING/MONITORING AGENCY REPORT NUMBER

12. DISTRIBUTION AVAILABILITY STATEMENT

National Technical Information Service

U.S. Department of Commerce

5285 Port Royal Road

Springfield, VA 22161

\section{SUPPLEMENTARY NOTES}

\section{ABSTRACT (Maximum 200 Words)}

Voluntary consumer decisions to purchase electricity supplied by renewable energy sources represent a powerful market support mechanism for renewable energy development. Beginning in the early 1990s, a small number of U.S. utilities began offering "green power" options to their customers. Since then, these products have become more prevalent, both from traditional utilities and from marketers operating in states that have introduced competition into their retail electricity markets. Today, more than half of all U.S. consumers have an option to purchase some type of green power product from a retail electricity provider. Currently, more than 600 utilities, or about $20 \%$ of utilities nationally, offer green power programs to customers. These programs allow customers to purchase some portion of their power supply as renewable energy_almost always at a higher price-or to contribute funds for the utility to invest in renewable energy development. The term "green pricing" is typically used to refer to these utility programs offered in regulated or noncompetitive electricity markets. This report documents green power marketing activities and trends in the United States.

\section{SUBJECT TERMS}

Green power; green power marketing; green tags; voluntary markets; renewable energy markets; utilities; electricity customers; energy industry trends; renewable energy certificates; RECs; green power products; consumer response; utility green pricing programs; Lori Bird; Blair Swezey

\begin{tabular}{|c|c|c|c|c|}
\hline \multicolumn{3}{|c|}{ 16. SECURITY CLASSIFICATION OF: } & \multirow{2}{*}{$\begin{array}{l}\text { 17. LIMITATION } \\
\text { OF ABSTRACT } \\
\text { UL }\end{array}$} & \multirow{2}{*}{$\begin{array}{ll}\text { 18. } & \text { NUMBER } \\
\text { OF PAGES }\end{array}$} \\
\hline $\begin{array}{l}\text { a. REPORT } \\
\text { Unclassified }\end{array}$ & $\begin{array}{l}\text { b. ABSTRACT } \\
\text { Unclassified }\end{array}$ & $\begin{array}{l}\text { c. THIS PAGE } \\
\text { Unclassified }\end{array}$ & & \\
\hline
\end{tabular}

19a. NAME OF RESPONSIBLE PERSON 19b. TELEPHONE NUMBER (Include area code) 